\title{
Perspectiva Histórica e Tecnológica da Calibração do Túnel 2 do Sistema Cantareira de Adução de Água para a Região Metropolitana de São Paulo
}

\author{
Hemerson D. Pinheiro
}

Dissertação apresentada à Escola de Engenharia de São Carlos da Universidade de São Paulo, como parte dos requisitos para obtenção do título de Mestre em Engenharia Hidráulica

Orientador: Prof. Dr. Marcius Fantozzi Giorgetti 
Candidato: Licenciado HEMERSON DONIZETE PINHEIRO

Dissertação defendida e julgada em 22-03-2007 perante a Comissão Julgadora:

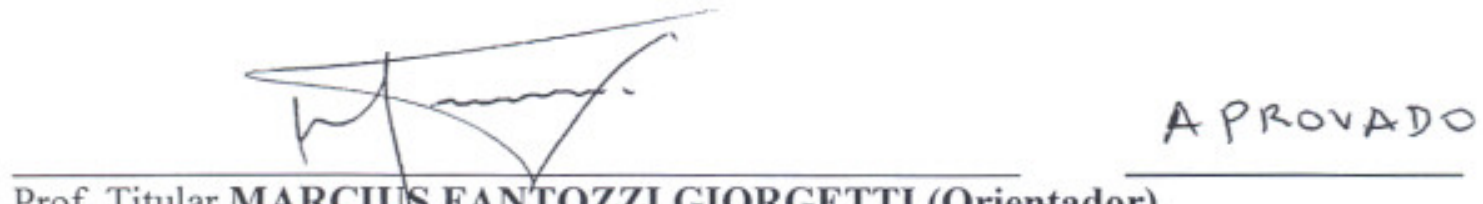

Prof. Titular MARCIUS FANTOZZI GIORGETTI (Orientador)

(Escola de Engenharia de São Carlos/USP)

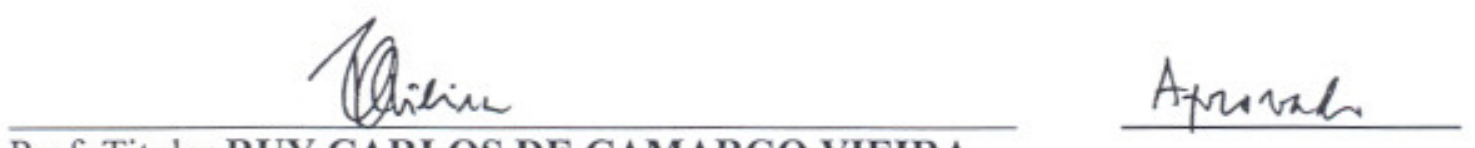

Prof. Titular RUY CARLOS DE CAMARGO VIEIRA

(Escola de Engenharia de São Carlos/USP)

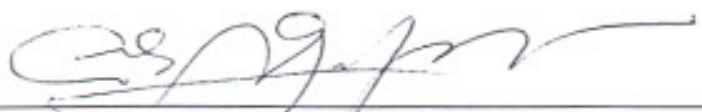

Apurado

Prof. Dr. CARLOSALBERTO GASPARETTO

(Faculdade de Engenharia de Sorocaba/FACENS)

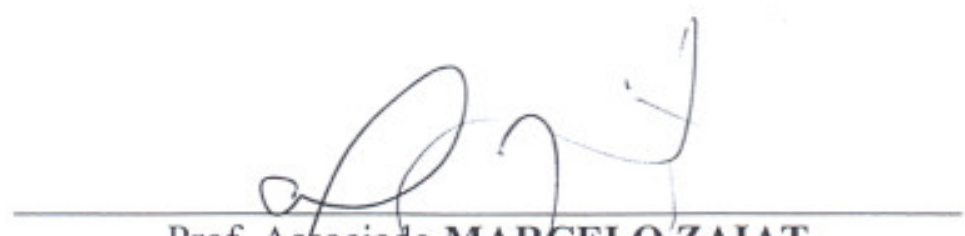

Prof. Associado MARCELO ZAIAT

Coordenador do Programa de Pós-Graduação

em Engenharia (Hidráulica e Saneamento)

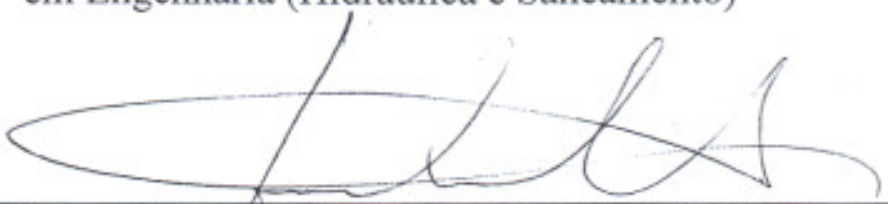

Prof. Associado GERALDO ROBERTO MARTINS DA COSTA

Presidente da Comissão da Pós-Graduação da EESC 
O autor e eu desejamos registrar a valiosíssima contribuição dada pelo engenheiro e professor Mauriney (Ney) Vilela ao longo de todo este trabalho.

A bem da verdade e da justiça, queremos reconhecer nesta contribuição um ato de co-orientação de fato, já que as disposições vigentes não prevêem a figura da co-orientação em pesquisas de mestrado.

Os ensaios do Túnel 2 do Sistema Cantareira foram trabalhos de grande envergadura, em particular na época em que foram executados.

Nos registros históricos encontrados pelo primeiro signatário desta página, assim como, nas lembranças pessoais do segundo, se identificam a liderança e capacidade de trabalho do Professor Ruy Carlos de Camargo Vieira como a mola mestra que fez acontecer este projeto.

A esta mesma liderança, revelam os registros, se devem a criação e desenvolvimento da Cátedra de Física Técnica e do Departamento de Hidráulica e Saneamento, assim como do CRHEA, em suas fases iniciais de definição e implantação.

Hemerson D. Pinheiro 
Ao professor Marcius F. Giorgetti pela orientação deste trabalho.

Ao professor Ney Vilela que, pela co-orientação, propiciou-me a oportunidade de aprofundar meus estudos.

À Nádia, minha companheira, e à família pelo amor e compreensão.

Aos professores entrevistados que dispuseram de seu tempo comigo.

Aos amigos que direta ou indiretamente estiveram presentes na efetivação dessa etapa.

À CAPES e à EESC, que possibilitaram materialmente a realização deste trabalho.

À SABESP pelo empréstimo dos relatórios referentes aos ensaios. 


\section{Conteúdo}

Lista de Abreviaturas e Siglas iv

Lista de Figuras vi v vi v

$\begin{array}{ll}\text { Lista de Tabelas } & \text { ix }\end{array}$

Resumo $\quad$ x

Abstract $\quad$ xi

1 Introdução e Objetivos 1

2 Revisão Bibliográfica $\quad 6$

2.1 Técnica e Tecnologia . . . . . . . . . . . . . 6

2.2 O Sistema Cantareira . . . . . . . . . . . . . . 11

2.3 O Túnel $2 \ldots \ldots \ldots \ldots$

2.4 Departamento de Hidráulica e Saneamento: Contribuições à Engenharia no Brasil . . . . . . . . . . . . . . . . . . . . . . . 24

$\begin{array}{lll}3 & \text { Metodologia } & 27\end{array}$

3.1 As Fontes . . . . . . . . . . . . . . . . . . . . . . . . . . . . . . 29

3.2 Organização do Material e Procedimentos da Análise . . . . . . . 33

4 As Técnicas e Tecnologias Usadas nos Ensaios do Túnel $2 \quad 35$

4.1 Determinação das perdas de carga . . . . . . . . . . . . . . 39

4.1 .1 Circulação de Ar . . . . . . . . . . . . . . . . . . 42

4.1 .2 Medidor da Vazão . . . . . . . . . . . . . . . . . . . . . . 49

4.2 O Método Óptico . . . . . . . . . . . . . . . . . . . 57

4.2.1 Método Óptico Desenvolvido pelo SHS . . . . . . . . . . 61 
5 Os Ensaios do Túnel $2 \quad 72$

5.1 Os Ensaios de Perda de Carga com Circulação de Ar . . . . . . . 74

$5.1 .1 \quad$ Ensaio Preliminar . . . . . . . . . . . . 76

5.1 .2 Segundo Ensaio . . . . . . . . . . . . . . 83

6 Considerações Finais $\quad 92$

$\begin{array}{ll}\text { A Entrevistas } & 100\end{array}$

A.1 Entrevista com o Professor Hans George Arens . . . . . . . . . 100

A.2 Entrevista com o Professor Dante Contin Neto . . . . . . . . . . 117

A.3 Entrevista com o Professor Antonio Marozzi Righetto . . . . . . 129

A.4 Entrevista com o Professor Ruy Vieira . . . . . . . . . . . . . . . 141

A.5 Entrevista com o Professor Geraldo Lombardi . . . . . . . . . . . 161

B DVD com trechos dos filmes gravados durante os Ensaios do Túnel 2

$\begin{array}{lll}\text { C DVD com fotos dos Ensaios do Túnel } 2 & 171\end{array}$

$\begin{array}{lr}\text { Bibliografia } & 172\end{array}$ 


\section{Lista de Abreviaturas e Siglas}

EESC Escola de Engenharia de São Carlos

ABENGE Associação Brasileira de Ensino de Engenharia

ASME American Society of Mechanical Engineers

CEPA Comissão Especial para o Planejamento das Obras de Abastecimento e Distribuição de Água da Cidade de São Paulo

CESP Companhia Energética de São Paulo

CNPq Conselho Nacional de Desenvolvimento Científico e Tecnológico

COMASP Companhia Metropolitana de Água de São Paulo

CONFEA Conselho Federal de Engenharia, Arquitetura e Agronomia

CRHEA Centro de Recursos Hídricos e Ecologia Aplicada

DAE Departamento de Água e Esgoto

DAEE Departamento de Águas e Energia Elétrica

ESI Elevatória Santa Inês 
ETA Estação de tratamento de Água

ITA Instituto Tecnológico de Aeronáutica

MEC Ministério da Educação e Cultura

RMSP Região Metropolitana de São Paulo

SABESP Companhia de Saneamento Básico do Estado de São Paulo

SAM Sistema Adutor Metropolitano

SHS Departamento de Hidráulica e Sanemanto

TNT Trinitro-Tolueno

USP Universidade de São Paulo 


\section{Lista de Figuras}

Figura 1.1 Perfil Hidráulico esquemático do Sistema Cantareira - Ilustração de $2004 \ldots$. . . . . . . . . . . . . . . . . . 2

Figura 2.1 Perfil Hidráulico esquemático do Sistema Cantareira - Ilustração de $1970 \ldots \ldots$. . . . . . . . . . . . . . . 19

Figura 2.2 Sistema Cantareira - Ilustração de 1970 . . . . . . . . . . 20

Figura 2.3 Seção tipo 5 e tipo $6 \ldots \ldots$. . . . . . . . . . 23

Figura 4.1 Diagrama de Moody (L. F. Moody, Trans. ASME, vol.

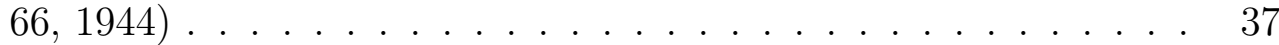

Figura 4.2 Instalação dos Ventiladores - Ensaio Preliminar . . . . . . 44

Figura 4.3 Montagem dos ventiladores - vista do interior - Segundo Ensaio . . . . . . . . . . . . . . . . . . 44

Figura 4.4 Montagem dos ventiladores - vista externa - Segundo Ensaio 45

Figura 4.5 Comparação entre a curva característica do ventilador fornecida pelo fabricante e a obtida no ensaio (SHS, 1969). . . . . 46

Figura 4.6 Ensaio do Ventilador - 1972 . . . . . . . . . . . . 47

Figura 4.7 Verificação da rotação dos ventiladores com o uso de um estroboscópio . . . . . . . . . . . . . . . . . . . . . . . . . 48

Figura 4.8 Central de acionamento dos ventiladores . . . . . . . . . . 48

Figura 4.9 Execução do diafragma em cambotas de cedro . . . . . . 52 
Figura 4.10 Execução do diafragma . . . . . . . . . . . . . . . . . 53

Figura 4.11 Montagem do diafragma e sua armação estrutural . . . . 53

Figura 4.12 Molde para modelagem do modelo do Túnel $2 \ldots$. . . . . 54

Figura 4.13 Modelo reduzido do Túnel 2 em gesso . . . . . . . . . . . 54

Figura 4.14 Modelo reduzido do trecho inicial de montante do Túnel 2 com o diafragma . . . . . . . . . . . . . . 55

Figura 4.15 Bancada de ensaios do modelo reduzido . . . . . . . . 55

Figura 4.16 Modelo reduzido do Túnel 2 - Segundo Ensaio . . . . . . 56

Figura 4.17 Diafragma modelo - Segundo Ensaio . . . . . . . . . . . . 57

Figura 4.18 Tomada de pressão no diafragma - Segundo Ensaio . . . . 57

Figura 4.19 Medição da vazão no diafragma com Anemômetro Lambrecht - Segundo Ensaio . . . . . . . . . . . . . . 58

Figura 4.20 Diafragma - Segundo Ensaio . . . . . . . . . . . . 58

Figura 4.21 Exemplo de sobreescavação . . . . . . . . . . . . . . . . . 59

Figura 4.22 Seção do túnel mostrando as linhas de projeto e zonas de sobreescavação e subescavação. . . . . . . . . . . . . . . . 59

Figura 4.23 Protótipo do Equipamento do Método Óptico . . . . . . . 62

Figura 4.24 Projetor luminoso com lâmpadas . . . . . . . . . . . . . 63

Figura 4.25 Sistema de ventilação do projetor . . . . . . . . . . . . . 64

Figura 4.26 Flash Toroidal utilizado no Método Óptico . . . . . . . . 64

Figura 4.27 Equipamentos do Método Óptico - (a) equipamento usado para levantamento dos perfis do Túnel 2 e (b) protótipo do equipamento .................... 65

Figura 4.28 Exemplo de um perfil do Túnel 2 obtido com o Método Óptico ............................ 65 
Figura 4.29 Cavalete usado para acomodar os equipamentos utilizados no Método Óptico . . . . . . . . . . . . . . . . . . . . 67

Figura 4.30 Perfil Escavado . . . . . . . . . . . . . . . . . . . . . . . . . 68

Figura 4.31 Perfil Medido . . . . . . . . . . . . . . . . . . . . 68

Figura 4.32 Imprecisões obtidas usando o método dos ângulos fixos . . 69

Figura 4.33 Método das fitas paralelas . . . . . . . . . . . . . . . 70

Figura 4.34 Perfil obtido com o método das fitas paralelas e o perfil projetado ........................ 70

Figura 4.35 Comparação entre o perfil escavado e o obtido com o método das fitas paralelas . . . . . . . . . . . . . 71

Figura 5.1 Esquema do Sistema de Medição usado no Ensaio Preliminar 78

Figura 5.2 Curva da Perda Total no Túnel 2 - Ensaio Preliminar . . 81

Figura 5.3 Esquema do Sistema de Medição usado no Segundo Ensaio 84

Figura 5.4 Levantamento fotográfico das seções transversais do desemboque do Túnel 2 - Segundo Ensaio . . . . . . . . . . . 85

Figura 5.5 Diafragma instalado no desemboque do Túnel 2 - Segundo Ensaio . . . . . . . . . . . . . . . . 86

Figura 5.6 Caminhão utilizado para transporte dos equipamentos Segundo Ensaio . . . . . . . . . . . . . . . . . . 87

Figura 5.7 Curva das perdas de carga - Segundo Ensaio . . . . . . . 91 


\section{Lista de Tabelas}

Tabela 2.1 Sistema Juquerí em 1965 . . . . . . . . . . . . . . . . . 14

Tabela 2.2 Etapas da construção do Sistema Cantareira . . . . . . . 17

Tabela 2.3 Reservatórios, Túneis e Elevatória do Sistema Cantareira 18

Tabela 4.1 Características das principais seções do Túnel 2 . . . . . . 41

Tabela 4.2 Comparação entre as medidas realizadas com o Método Óptico e com o Teodolito . . . . . . . . . . . . . . 66

Tabela 4.3 Tempo gasto com o método dos ângulos fixos . . . . . . . 69

Tabela 4.4 Tempo gasto com o método das fitas paralelas . . . . . . 70

Tabela 5.1 Perdas - Ensaio Preliminar . . . . . . . . . . . . . . 80

Tabela 5.2 Vazões obtidas com o escoamento de ar . . . . . . . . 88 


\section{Resumo}

PINHEIRO, Hemerson D. Perspectiva Histórica e Tecnológica da Calibração do Túnel 2 do Sistema Cantareira de Adução de Água para a Região Metropolitana de São Paulo. 2007. 178 f. Dissertação (Mestrado) Escola de Engenharia de São Carlos, Universidade de São Paulo, 1995.

Trabalhos de cunho historiográfico que visam resgatar a produção científica e tecnológica de um país têm auxiliado a compreender e a classificar seu nível de desenvolvimento frente a estas questões. Com este trabalho, espera-se dar início no Departamento de Hidráulica e Saneamento (SHS) da Escola de Engenharia de São Carlos, a um levantamento historiográfico da produção tecnológica e científica de seus pós-graduandos e professores. Para tanto, resgata-se um trabalho realizado entre o final da década de 1960 e início da década de 1970, pela Cátedra de Mecânica dos Fluidos (precursora do SHS), que teve como objetivo prever a vazão de água do Túnel 2 do Sistema Cantareira de Abastecimento de Água para a Região Metropolitana de São Paulo. Nesta galeria foi realizado um ensaio original com circulação de ar, para o qual foram desenvolvidos métodos e técnicas a fim de verificar a vazão e auxiliar no seu dimensionamento, para garantir uma adução de $33 \mathrm{~m}^{3} / \mathrm{s}$. Mediante o levantamento, organização cronológica e análise dos documentos produzidos pelos autores do referido ensaio, resgatam-se as influências teóricas que nortearam as metodologias, as técnicas e tecnologias e analisam-se, de acordo com os registros documentais, a execução e resultados alcançados pelos ensaios.

Palavras-chave: Hidráulica; Modelo Físico; Análise Dimensional e de Semelhança; Ensaio de Túnel de Adução; Sistema Cantareira; Relato Histórico. 


\section{Abstract}

PINHEIRO, Hemerson D. Historical and Technological Perspective of the Test for the Calibration of Tunnel 2 of the Cantareira Water Project for the Metropolitan Area of São Paulo. 2007. 178 p. Dissertação (Mestrado) - Escola de Engenharia de São Carlos, Universidade de São Paulo, 1995.

Works that have as objective to review the scientific and technological production of a country have helped to understand and to measure its level of development regarding these questions. With this work, hopefully a historical survey of the technological and scientific production of its graduate students and teachers begins at the Departamento de Hidráulica e Saneamento (SHS) at the Escola de Engenharia de São Carlos. In this way, a work that was carried out between the end of the 1960's and beginning of the 1970's, by the Chair of Fluid Mechanics (precursor of the SHS), which had as objective to foresee the water flow rate at Tunnel 2 of the Cantareira Water Project for the Metropolitan Area of São Paulo. An original test using air circulation was carried out in the tunnel. Methods and techniques were developed in order to verify the flow rate and check its size, to guarantee $33 \mathrm{~m}^{3} / \mathrm{s}$ of flow. The documents produced by the authors of the test were surveyed, organised chronologically and analysed, seeking to infer the theoretical influences that had guided the methodologies, to describe the techniques and technologies and to analyze, in accordance with the document registers, the execution and results reached from the tests.

Key-words: Hydraulic; Physical Model; Dimensional Analysis and Similarity ; Tests of the Tunnel for Water Flow Rate; Sistema Cantareira; Historical Review. 


\section{Capítulo 1}

\section{Introdução e Objetivos}

Com a finalidade de suprir as demandas por água potável para a Região Metropolitana de São Paulo (RMSP), a Companhia Metropolitana de Água de São Paulo (COMASP) iniciou no ano de 1967 a construção do Sistema Cantareira (Sistema adutor de água para Região Metropolitana de São Paulo).

Este sistema de adução de água compreendeu um conjunto de obras com sete túneis para aduzir as águas captadas dos rios Jaguarí, Jacareí, Cachoeira, Atibainha e Juquerí para a Estação de Tratamento de Água do Guaraú (ETA Guaraú) .

O Túnel 2, com extensão de $4.826 m$, é o último túnel desse conjunto (figura 1.1), faz a ligação entre o reservatório de Águas Claras e a ETA Guaraú, aduzindo $33 \mathrm{~m}^{3}$ de água por segundo. Esta não foi a vazão projetada para o túnel. O projeto inicial do Sistema Cantareira previa uma vazão máxima de $22 \mathrm{~m}^{3} / \mathrm{s}$ para o Túnel 2 e para essa vazão ele foi escavado. Estudos posteriores à escavação 
do túnel concluiram que a capacidade do Sistema Cantareira poderia ser ampliada para $33 \mathrm{~m}^{3} / \mathrm{s}$, com isso tornou-se necessária a modificação das dimensões do túnel. Frente a essa necessidade, a Escola de Engenharia de São Carlos (EESC) da Universidade de São Paulo (USP), mais precisamente o Departamento de Hidráulica e Saneamento (SHS), foi então contratado para realizar uma assessoria quanto ao redimensionamento do Túnel 2, através do estudo das perdas de carga.

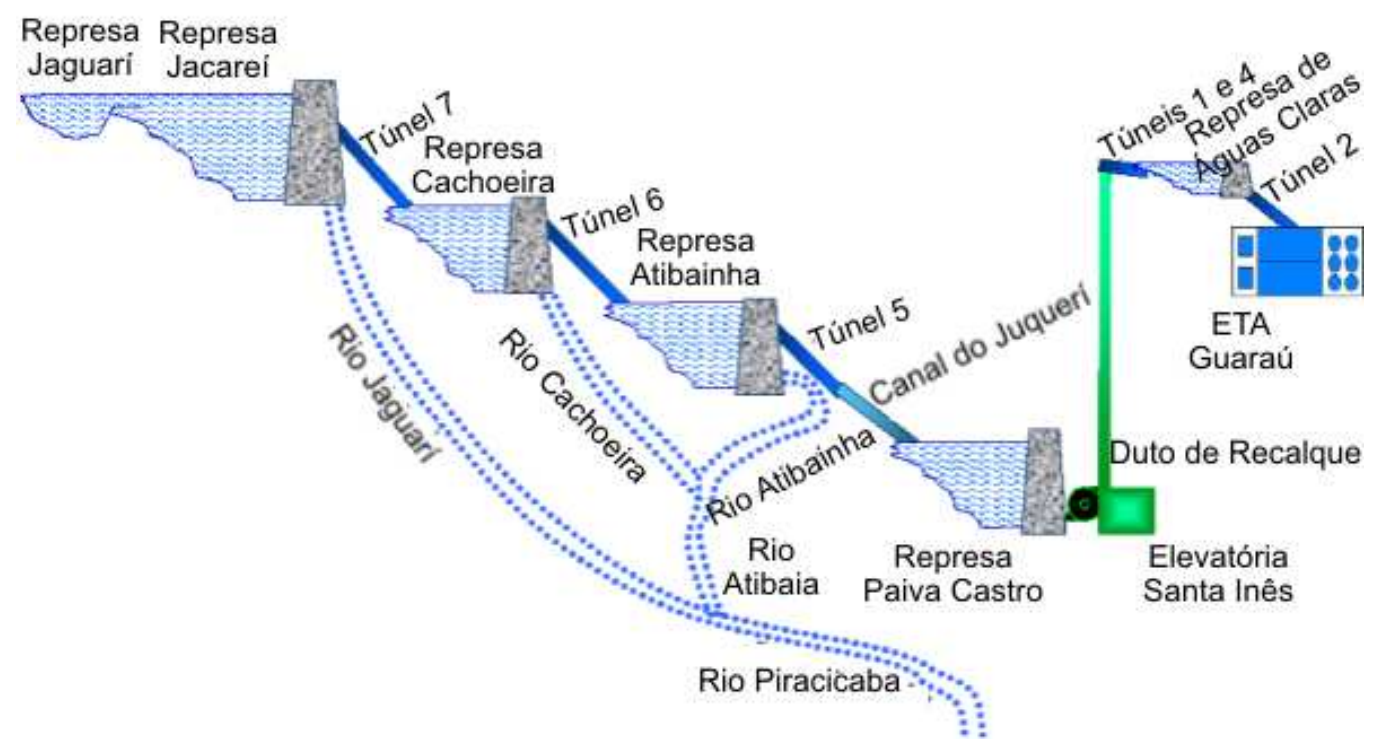

Figura 1.1: Perfil Hidráulico esquemático do Sistema Cantareira - Ilustração de 2004

Durante a construção do Sistema Cantareira, o SHS prestou outras assessorias à COMASP como:

- Auxilio à seleção de Bombas Hidráulicas para a Elevatória Santa Inês;

- Aproveitamento Hidroelétrico a Jusante do Reservatório de Águas Claras;

- Golpe de Ariete;

- Perda de Carga na Chaminé de Equilíbrio;

- Bacia de Dissipação de Energia da ETA Guaraú; 
- Bocais Dispersores.

O estudo das perdas de carga no Túnel 2 constou de dois ensaios ${ }^{1}$ com circulação de ar realizados no próprio túnel e em modelos reduzidos. Nesses ensaios foram avaliadas as perdas quando da circulação de água a partir dos dados obtidos para a vazão forçada de ar. O primeiro ensaio, realizado durante as obras de rebaixamento, teve como objetivo auxiliar no redimensionamento e o segundo teve como finalidade verificar se, ao final das obras, o túnel atenderia à vazão de projeto $\left(33 m^{3} / s\right)$.

As determinações da perda de carga global foram realizadas para diversas vazões do escoamento de ar, dentro das possibilidades de operação dos ventiladores existentes. Os resultados foram colocados em forma de curva característica de perda de carga do túnel, mantida a geometria existente.

A medida de perda de carga foi feita com tubos de Pitot, colocados adequadamente no emboque e no desemboque. O escoamento foi considerado como unidimensional, em face da preponderância das dimensões longitudinais da galeria, com relação às suas dimensões transversais, de maneira a se obter a maior precisão possível nas medidas.

A vazão de ar foi aferida com medidor de orifício do tipo diafragma, inserido em trecho retilíneo do emboque, no Ensaio Preliminar, e no desemboque

\footnotetext{
${ }^{1}$ Foram realizados dois ensaios no Túnel 2 do Sistema Cantareira. O primeiro no ano de 1969 foi intitulado por seus autores (na documentação consultada para a presente pesquisa) por "Ensaio Preliminar", e assim ele será referenciado neste trabalho. O segundo ensaio, realizado em 1972, cujo objetivo foi verificar se as recomendações sugeridas no Ensaio Preliminar garantiam a vazão de projeto, foi denominado nos relatórios e demais documentos relativos a sua execução como "Ensaio de Perda de Carga do Túnel 2". Assim, para não haver possíveis divergências quando estiver generalizando os dois ensaios, no texto será utilizada a denominação Segundo Ensaio, quando se estiver tratando do ensaio realizado em 1972.
} 
do túnel, em trecho revestido, no segundo ensaio. O diafragma foi projetado e construído tomando-se as precauções estabelecidas em normas e de maneira a ser facilmente montado e transportado; foi calibrado através de um modelo reduzido e o seu coeficiente de vazão, em função do número de Reynolds, foi obtido dentro da gama de variação correspondente ao escoamento no túnel.

O escoamento forçado de ar através da galeria foi obtido com três ventiladores SEI adquiridos pela COMASP, montados no desemboque. Para o segundo ensaio do Túnel 2, foi obtida em laboratório a curva característica dos ventiladores. O ensaio dos ventiladores teve como finalidade comprovar que no túnel seria obtida a vazão de ar dentro dos limites previstos, pois somente desta maneira seria possível atingir a precisão proposta e também para contornar os problemas ocorridos durante o ensaio preliminar, quando os ventiladores utilizados não obedeceram as curvas fornecidas pelo fabricante.

O ensaio dos ventiladores obedeceu às normas usuais, tendo como finalidade a obtenção das curvas características de pressão total em função da vazão, controlando-se simultaneamente a ordem de grandeza da potência elétrica dos motores de acionamento.

Com os resultado dos ensaios de campo e de laboratório, foi obtida a curva característica de perda de carga do Túnel 2 no escoamento de água a partir do escoamento de ar.

Para a aplicação do método na predeterminação das perdas de carga, foram necessários: 
- Conjunto de três ventiladores axiais;

- Estação medidora da vazão;

- Medidores da pressão estática ao longo do túnel;

- Sistema de telecomunicação.

É sobre as técnicas e tecnologias empregadas a esses dois ensaios que versa essa pesquisa, com o objetivo de dar início à construção de uma historiografia da tecnologia produzida pelo Departamento de Hidráulica e Saneamento (SHS) da Escola de Engenharia de São Carlos (EESC), para tanto, abordando os trabalhos realizados entre o final da década de 1960 e início da década de 1970 pela Cátedra de Mecânica dos Fluidos, precursora do SHS, na determinação das perdas de carga do Túnel 2 do Sistema Cantareira.

A intenção deste trabalho é contribuir para o surgimento de iniciativas e ações que assegurem visibilidade ao longevo esforço de produção do conhecimento do SHS e da própria EESC. A principal motivação para a realização é que a produção do conhecimento científico e tecnológico dos docentes, alunos e pesquisadores deste departamento, se confundem com o esforço da construção do SHS. Assim, um trabalho que inicie a construção da memória/história da ciência e tecnologia, produzida nesse departamento, é de indiscutível importância, pois não há como discutir perspectivas sem levar em conta a experiência vivida por seus pesquisadores. 


\section{Capítulo 2}

\section{Revisão Bibliográfica}

\subsection{Técnica e Tecnologia}

As palavras técnica e tecnologia são freqüentemente empregadas com sentidos confusos. Segundo Gama (1990), o problema do significado das palavras técnica e tecnologia tem duas origens: a primeira é aparentemente semântica, decorrente da adoção do termo tecnologia como tradução do inglês technology, e a segunda é devida ao fato de a teoria (ciência) ocupar lugar "privilegiado" em relação à prática (à técnica, ao trabalho).

Tecnologia comumente é usada com sentido de técnica em geral, ou mesmo num sentido menor, como por exemplo, o do trato com aparelhagem ou processos de fabricação sofisticados, e mesmo num sentido comercial, muito próximo de marketing (VARGAS, 1994). A palavra inglesa technology, cobre um vasto campo de significados, indo desde o que se entende, em português, por técnica ou 
conjunto de técnicas, até os instrumentos, ferramentas e objetos tecnicamente produzidos, bem como o know-how, o "saber-fazer" presente na produção industrial (GAMA, 1986). Para Mammana (1990), tecnologia deveria significar, como na terminologia tradicional designam as palavras biologia, geologia, embriologia ou psicologia o nome de uma ciência, a ciência que estuda a técnica (MAMMANA, 1990). E assim como Mammana, Gama (1990), define tecnologia como ciência: "tecnologia é a ciência do trabalho produtivo".

Do apresentado acima, faz-se necessário neste trabalho distinguir técnica de tecnologia, e essa última, de ciência. Assim, será assumido para técnica e tecnologia os mesmos significados encontrados na obra de Gama $(1986)^{1}$ :

Técnica: conjunto de regras práticas para fazer coisas determinadas, envolvendo a habilidade do executor e transmitidas, verbalmente, pelo exemplo, no uso das mãos, dos instrumentos e ferramentas e das máquinas. Alarga-se freqüentemente o conceito para nele incluir o conjunto dos processos de uma ciência, arte ou ofício, para obtenção de um resultado determinado com o melhor rendimento possível.

Tecnologia: estudo e conhecimento científico das operações técnicas ou da técnica. Compreende o estudo sistemático dos instrumentos, das ferramentas e das máquinas empregadas nos diversos ramos da técnica, dos gestos e dos tempos de trabalho e dos custos, dos materiais e da energia empregada. A tecnologia implica a aplicação dos métodos das ciências físicas e naturais e, como assinala (com propriedade mas não com primazia) Alain Birou ${ }^{2}$, também na comunicação desses conhecimentos pelo ensino técnico (Alain Birou apud Gama 1986).

Neste sentido, técnica será considerada como um simples "saber-fazer" e tecnologia como a utilização de conhecimentos científicos na solução de problemas

\footnotetext{
${ }^{1}$ Outros autores como Vargas (1994), Mammana (1990) e Motoyama (2002 e 1994), compartilham desta definição para técnica e tecnologia.

${ }^{2}$ Alain Birou. Dicionário das Ciências Sociais, Lisboa, Ed. d. Quixote, 1966.
} 
técnicos. Assim, a técnica é uma habilidade humana de fabricar, construir e utilizar instrumentos, sendo tão antiga quanto a humanidade:

... deve ter tido origem com o surgimento da habilidade de utilizar com destreza ambas as mão, em simultaneidade com a característica humana de utilizar símbolos, capazes de correlacionar objetos com o pensamento e o instinto humano (VARGAS, 1994).

Por sua vez a tecnologia, aplicação de uma teoria científica à solução de um problema técnico, aparece pela primeira vez na História com a publicação dos textos Discorsi e Demonstrazioni Matematiche intorno a Due Nuove Scienze ${ }^{3}$, por Galileu Galilei na Holanda em 1638 (VARGAS, 1995/1996). Neste trabalho, Galileu resolve o problema do cálculo de uma viga em balanço, mostrando que a viga romperá na sua aresta inferior (junto ao ponto em que está engastada a uma parede vertical) quando o momento da força aplicada em sua extremidade livre igualar-se ao momento da força resistente; para Galileu essa força é igual à metade da espessura da viga multiplicada pela resistência à tração do material da viga.

Na introdução do livro 50 Anos do CNPq contados por seus presidentes, o organizador da obra, Motoyama (2002), aponta a necessidade de pesquisas para explorar o que ele chamou de "território desconhecido", a história da Ciência e Tecnologia no Brasil, como uma necessidade para entender sua complexa situação contemporânea no país:

Não adianta apenas o diagnóstico do presente, porquanto este não

\footnotetext{
${ }^{3}$ A primeira dessas duas novas ciências é a Resistência dos Materiais - ciência aplicada básica da engenharia - e a segunda é parte da Mecânica Racional, correspondente aos movimentos locais (Vargas, 1995/1996).
} 
estaciona no tempo, mudando de configuração no decorrer do processo histórico. É preciso captar o sentido do futuro escondido no fluxo cambiante da passagem dos acontecimentos do passado para os de hoje. Os repetidos fracassos do planejamento - aqui e alhures - residem exatamente nesse olímpico desprezo pela história, notado na maioria dos planejadores hodiernos. Nesse aspecto, a reflexão histórica é parte indispensável da ação pelo futuro (MOTOYAMA, 2002) - grifos nossos.

Segundo o mesmo autor, as projeções para o futuro, quando feitas dentro de cenários alternativos, sem considerar preocupações sobre a existência de uma dinâmica real do processo do desenvolvimento, são ineficazes se "divorciadas das coordenadas históricas". Neste contexto, destaca-se a tecnologia, que deve ser considerada como uma variável formadora do processo de desenvolvimento industrial de um país, entretanto, essa questão é apenas discutida como um dado, "no máximo como um parâmetro integrante do capital" (MOTOYAMA, 1994).

Especialistas em História da Ciência e da Tecnologia, têm assinalado a lacuna de estudos que analisem, em sua plenitude, a tecnologia como um processo histórico ligado de modo intrínseco ao desenvolvimento, e, ao mesmo tempo, possuidor de uma dinâmica própria. Isso torna necessário repensar o significado da tecnologia e seu papel na conformação do conceito de desenvolvimento.

Assim como a abordagem de Motoyama (1994), sobre a falta de estudos históricos relacionando tecnologia e industrialização, no que se refere ao desenvolvimento de um país, no presente estudo adota-se a hipótese de que essa relação pode ser pensada também em contextos menores, como por exemplo, o papel da tecnologia no desenvolvimento de uma instituição de ensino e pesquisa. No caso da EESC, verificou-se que poucos estudos se ocuparam dessa discussão. 
Muitas vezes, como no caso da industrialização, os institutos de pesquisa privilegiam projetos e planos de outras instituições e de países mais desenvolvidos, por supostamente oferecerem soluções imediatas, deixando de lado as análises históricas, porque elas requerem mais tempo e trabalho original. Tem-se por hipótese que este é um dos fatores que justifica a pouca receptividade a propostas de estudos de cunho histórico, que mesmo tendo, no caso das instituições de ensino e pesquisa, a sua produção científica e tecnológica em forma de teses, dissertações, relatórios, etc., mais facilmente acessível em forma de dados em suas bibliotecas, são raras as análises ou estudos de cunho histórico, intentados a captar, na inteireza dessas produções, as diversas variáveis concernentes ao desenvolvimentos dessas instituições, desses centros de ensino e pesquisa.

A respeito da história da tecnologia no Brasil, cabe assinalar os livros de $\operatorname{Vargas}^{4}$, (1994) e Motoyama ${ }^{5}$ (1994). Esses dois trabalhos são frutos de pesquisas do Centro Interunidades de História da Ciência e da Tecnologia (CHC), da Universidade de São Paulo (USP), centro este que vem se dedicando à compreensão do estágio em que se encontra hoje a técnica e a tecnologia no Brasil. O trabalho de Vargas (1994) apresenta, em sua primeira parte, um panorama de como a técnica evoluiu à engenharia no Brasil Colônia e no Império; em seguida, trata da engenharia na República Velha até o pós-guerra e finaliza com textos sobre a tecnologia no período pós-guerra. Motoyama (1994), preocupado com a relação Tecnologia e Industrialização, organiza sua obra separando-a em três partes: a primeira, tratando da indústria da construção civil; a segunda parte é dedicada à

\footnotetext{
${ }^{4}$ Vargas, M. História da técnica e Tecnologia no Brasil. São Paulo: Editora Unesp, 1994.

${ }^{5}$ Motoyama, S. Tecnologia e Industrialização no Brasil. São Paulo: Editora Unesp, 1994.
} 
siderurgia, energia elétrica e química e a última parte do livro trata das indústrias do Estado de São Paulo (metal-mecânica, biotecnologia e informática).

Somando às obras citadas acima o trabalho de Silva Telles ${ }^{6}$ (1984), História da engenharia no Brasil (séculos XVI a XIX) $)^{7}$, temos um perfil da evolução da engenharia no Brasil, desde as técnicas das populações indígenas, das antigas técnicas de mineração (ouro e pedras preciosa), até o estágio atual da engenharia brasileira.

Outro autor que tem apresentado importantes trabalhos sobre a história da técnica e da tecnologia é Gama (1990, 1986, 1985), que apresenta em seu livro História da Técnica e da Tecnologia (1985), uma coleção de textos básicos sobre a história da Técnica e da Ciência, alguns do final do século XVIII, escritos por Johann Beckmann, considerado o "pai da tecnologia".

\section{$2.2 \quad$ O Sistema Cantareira}

O Sistema Cantareira é o maior sistema adutor de água para a região metropolitana de São Paulo. Capta água dos rios Jaguarí, Jacareí, Cachoeira, Atibainha e Juquerí. Aduz 33 mil litros de água por segundo, abastecendo 8,8 milhões de pessoas nas zonas norte, central, parte da leste e oeste da Capital e os municípios de Franco da Rocha, Francisco Morato, Caieiras, Guarulhos (parte), Osasco, Carapicuíba, Barueri (parte), Taboão da Serra (parte), Santo André (parte) e

\footnotetext{
${ }^{6}$ Silva Telles, P. C. História da engenharia no Brasil (séculos XVI a XIX). Rio de Janeiro:LTC, 1984.

${ }^{7}$ Esta obra é considerada o mais completo inventário a respeito da História da Engenharia no Brasil (MOTOYAMA, 1994)
} 
São Caetano do Sul (SABESP, 2006).

A construção desse sistema representou um grande salto, tanto na quantidade quanto na qualidade da água tratada oferecida a RMSP. Trouxe também importantes inovações às técnicas de tratamento de água do Brasil e América Latina (AZEVEDO NETTO et al., 1978).

A estação de tratamento de água do Sistema Cantareira - ETA Guaraú - teve seu projeto básico concluído em 1968, sob a responsabilidade da firma SERETE Engenharia, que contratou como consultora a JAMES M. MONTGOMERY (J.M.M), renomada empresa de Pasadena, Califórnia, que incorporou ao projeto os mais modernos recursos tecnológicos, disponíveis até então, no tratamento de água. (AZEVEDO NETTO et al., 1978).

O desenvolvimento dos estudos, em parceria com a empresa J.M.M, teve como objetivo apresentar e discutir questões relacionadas com a evolução tecnológica ocorrida no campo da purificação das águas. Segundo Azevedo Netto et al. (1978):

Deve-se a essa iniciativa a introdução em nosso meio de uma série de idéias e técnicas novas, dentre as quais podem ser destacadas: o emprego de polieletrólitos, critérios para projeto e avaliação de misturadores e floculadores com base no tipo de escoamento e no gradiente de velocidades, melhor conceituação para os fatores críticos de projeto dos decantadores convencionais, diversas inovações no projeto de filtros rápidos de dupla camada, incluindo novo sistema de controle das vazões e novo tipo de fundo de filtro, sistemas centrais de comando, etc (AZEVEDO NETTO et al., 1978).

São Paulo, a exemplo de outras cidades brasileiras, teve como primeira forma de abastecimento de água a construção de chafarizes públicos. Antes disso 
as soluções eram individuais e ainda mais precárias, a população tinha de recorrer a fontes desprotegidas, pequenos cursos de água, etc. (AZEVEDO NETTO, 1976).

A evolução do serviço de abastecimento de água para a Capital e a Região Metropolitana, tem uma história de crises periódicas e sucessivas faltas de água (QUEIROZ, 1964; SAVELLI, 1964; CASTRO, 1965; QUEIROZ, 1966; AZEVEDO NETTO, 1976). Castro (1965) afirma que um dos fatores responsáveis pelo problema do abastecimento de água foi o crescimento vertiginoso e imprevisível da metrópole e a conseqüente inadequabilidade dos estudos e planejamentos feitos.

Segundo Azevedo Netto (1978), em 1966 a cidade de São Paulo, com cerca de 5 milhões de habitantes, abastecia apenas a $69 \%$ da população, com aproximadamente 300 litros diários por habitante. A ampliação do sistema adutor era, portanto, uma necessidade urgente e reconhecia-se a conveniência de se utilizar obra de grande porte, ampliando-se a escala dos empreendimentos.

Os estudos realizados pela $\mathrm{CEPA}^{8}$ - Comissão Especial para o Planejamento das Obras de Abastecimento e Distribuição de Água da Cidade de São Paulo - levaram as autoridades da época (Governo do Estado e prefeitos da região) a concluírem que a solução para o problema do abastecimento da RMSP estava no aproveitamento de água dos rios Juquerí, Atibainha, Cachoeira e Jaguarí, ou seja, na construção do Sistema Juquerí.

\footnotetext{
${ }^{8}$ A CEPA foi criada em abril de 1962 e por portaria da Diretoria Geral do DAE, em 1965 foi dispensada dos demais trabalhos que realizava, para se concentrar, unicamente, no Planejamento Geral de Águas e dos Esgotos Sanitários da Cidade.
} 
O primeiro estudo para aproveitamento de águas do rio Juquerí ${ }^{9}$ para abastecimento da RMSP, encontrado na Revista DAE (Revista do Departamento de Água Esgoto), data de 1964 e pode ser considerado como um ante-projeto do Sistema Juquerí. Em 1965, sob o título O Problema do Abastecimento de Água para a Área Metropolitana de São Paulo, o Eng. Paulo de Paiva Castro, Diretor da Divisão de Planejamento e Obras do DAE (Departamento de Água e Esgoto), apresentou a previsão dos volumes de água a serem aduzidos pelo Sistema Juquerí para a RMSP, baseado nos estudos realizados no ano de 1964. A previsão feita para as capacidades de cada rio do sistema são apresentadas na tabela 2.1.

Tabela 2.1: Sistema Juquerí em 1965

\begin{tabular}{lc}
\multicolumn{1}{c}{ Rio } & Adução $\left(\mathrm{m}^{3} / \mathrm{s}\right)$ \\
\hline Juquerí & 2,0 \\
Atibainha & 3,0 \\
Cahoeira & 5,0 \\
Jaguarí & 7,0 \\
\hline Total & $\mathbf{1 7} \mathrm{m}^{3} / \mathrm{s}$ \\
\hline Fonte: Castro, 1965
\end{tabular}

Em 1966 o aproveitamento do Sistema Juquerí ainda encontrava-se em fase de projeto e início de construção da etapa correspondente ao rio Juquerí (QUEIROZ, 1966). Frente ao atraso dos estudos e projetos, a administração da Secretaria dos Serviços de Obras Públicas do Estado de São Paulo decidiu, em 1967, dar solução efetiva ao problema do abastecimento de água na capital e cidades circunvizinhas, através de solução integrada abrangendo toda RMSP. A região tinha uma demanda de $22 \mathrm{~m}^{3} / \mathrm{s}$ e o fornecimento era de apenas $14 \mathrm{~m}^{3} / \mathrm{s}$ (JEZLER, 1970).

\footnotetext{
${ }^{9} \mathrm{O}$ Rio Juquerí corre em direção oeste à cidade de São Paulo, paralelamente à crista da Serra da Cantareira, a uma distância de $10 \mathrm{~km}$ desta.
} 
A solução encontrada foi a constituição da Companhia Metropolitana de Água de São Paulo - COMASP ${ }^{10}$, uma companhia organizada nos moldes de uma empresa privada, com o objetivo de aduzir a água necessária para a região e vendê-la por atacado a cada serviço municipal, que se encarregava dos problemas de distribuição e relações com os usuários.

Criada em 07/02/1968, a COMASP teve como principais subscritores do seu capital inical, duas entidades autárquicas do Governo do Estado de São Paulo: o Departamento de Águas e Energia Elétrica - DAEE, que subscreveu 81,3\% do capital para gradativa integralização em dinheiro e o Departamento de Águas e Esgotos - DAE, que compôs sua participação entregando à COMASP bens e serviços de sua propriedade, representados por equipamentos, materiais, bens desapropriados pelo Estado, completando os restantes 18,7\% (JEZLER, 1968).

Juntamente com os bens e serviços, a COMASP incorporou o acervo de obras dos Sistemas Juquerí e Capivari-Monos.

Cabe ressaltar aqui que o aproveitamento dos mananciais da Serra da Cantareira é datado de $1890^{11}$, com a denominação Sistema Cantareira. Em 1968 este sistema contribuía com $0,2 \mathrm{~m}^{3} / \mathrm{s}$ para o abastecimento da cidade de São Paulo (JEZLER, 1968). Em março de 1970, em nota ao "Diário Popular"

\footnotetext{
${ }^{10}$ Essa Companhia, em estágio subseqüente após cinco anos, deu origem à SABESP (Companhia de Saneamento Básico do Estado de São Paulo), mediante fusão com a SANESP e absorção dos remanescentes órgãos públicos estaduais de saneamento básico (AZEVEDO NETTO et al., 1978).

${ }^{11}$ As publicações encontradas na biblioteca do Departamento de Águas e Esgotos (DAE), fazem menção ao abastecimento de água da Capital, somente a partir de 1890, época em que explorava tais serviços era a Companhia Cantareira, que foi substituída pelo Governo do Estado em 1893, em conseqüência dos serviços deficientes que vinha prestando, pelo RAE - Repartição de Águas e Esgotos (QUEIROZ, 1964).
} 
(edição de 31/03/1970), a COMASP comunica a mudança do nome do Sistema Juquerí para Sistema Cantareira. Com isso, o antigo Sistema Cantareira, com essa denominação desde 1890 e o Sistema Juquerí passam a ter uma única denominação: Sistema Cantareira. Embora essa mudança de nome tenha ocorrido em março, apenas em setembro de 1970 é que a EESC recebe a notificação; isso justifica o fato de que nos primeiros relatórios sobre os ensaios do Túnel 2, é utilizada a nomenclatura Sistema Juquerí e não Cantareira. Na mesma notificação é apresentada também a nova denominação do conjunto de obras para a entrega da água dentro da RMSP: SAM - Sistema Adutor Metropolitano.

Os estudos realizados até o ano de 1967, segundo nota da empresa SERETE S.A. Engenharia, responsável pelo projeto e construção da Elevatória Santa Inês ${ }^{12}$ (ESI) (FERREIRA, 1969), conduziram a construção do Sistema Cantareira em duas etapas: a primeira etapa compreenderia a captação, recalque e adução das águas do rio Juquerí até a ETA do Guaraú e posteriormente, a captação e desvio dos rios Atibainha e Cachoeira para o rio Juquerí, constituindo a segunda fase e completando a primeira etapa; a segunda etapa consistiu na captação e desvio do rio Jaguarí.

Os estudos e projetos elaborados para o "Sistema Juquerî" atribuíram a este uma capacidade total de $22 \mathrm{~m}^{3} / \mathrm{s}$, o que resolveria o problema de abastecimento de água para a RMSP apenas a curto prazo. Estudos posteriores ao início das obras mostraram que a capacidade do sistema poderia ser ampliada, e assim

\footnotetext{
${ }^{12} \mathrm{~A}$ ESI possui 4 grupos moto-bombas $\left(3+1\right.$ reserva) que recalcam $11 \mathrm{~m}^{3} / \mathrm{s}$ nominais, com vazão máxima de $33,0 \mathrm{~m}^{3} / \mathrm{s}$, a uma altura manométrica de $120 \mathrm{~m}$, tendo cada bomba a potência de $20.000 \mathrm{HP}$.
} 
o fizeram, passando para $33 \mathrm{~m}^{3} / \mathrm{s}$ a capacidade do sistema. Isso obrigou a realização de adaptações às obras que já haviam sido iniciadas. No caso do Túnel 2, sua escavação já estava finalizada e este atenderia à antiga vazão de $22 \mathrm{~m}^{3} / \mathrm{s}$. Frente a essa mudança na capacidade de tratamento de água para o sistema, o Túnel 2 teve de ter as dimensões de suas seções ampliadas para se adaptar à nova vazão.

Em 1975 tiveram início as operações relativas às obras da primeira etapa, que compreendeu o aproveitamento dos rios Juquerí, Atibainha e Cachoeira, fornecendo a vazão nominal de $11 \mathrm{~m}^{3} / \mathrm{s}$ para São Paulo. A segunda etapa das obras iniciou-se em 1976 e foi concluída em 1982. As obras compreenderam as barragens dos rios Jaguarí e Jacareí, e propiciaram a adução dos $33 \mathrm{~m}^{3} / \mathrm{s}$ previstos para o sistema ${ }^{13}$ (DAEE, 1986; SABESP,1989).

A tabela 2.2 ilustra as fases de construção do Sistema Cantareira e a tabela 2.3 apresenta um esquema sucinto do sistema. Um perfil esquemático e uma ilustração do sistema, ambos do ano de 1970, são apresentados nas figuras 2.1 e 2.2 respectivamente.

Tabela 2.2: Etapas da construção do Sistema Cantareira

\begin{tabular}{lll}
\hline \multicolumn{3}{c}{$\mathbf{1}^{\mathbf{a}}$ Fase: $\mathbf{1 1 , 0} \mathrm{m}^{3} / \mathrm{s}$} \\
\hline Obra & Período de Construção & Início de Operação \\
\hline Barragem de Águas Claras & 1969 a 1971 & novembro $/ 1973$ \\
Estação Elevatória Santa Inês & 1967 a 1972 & bombas 1 a 3: dezembro $/ 1973$ \\
& & bomba 4: outubro de 1993 \\
Barragem de Paiva Castro & 1968 a 1972 & maio $/ 1973$ \\
Barragem do Rio Atibainha & 1969 a 1973 & fevereiro $/ 1975$ \\
Barragem do Rio Cachoeira & 1969 a 1974 & novembro $/ 1974$ \\
\hline \multicolumn{2}{l}{$\mathbf{2}^{a}$ Fase: $\mathbf{2 2 ~} \mathrm{m}^{3} / \mathrm{s}-$ Total: $\mathbf{3 3} \mathrm{m}^{3} / \mathrm{s}$} \\
\hline Barragens dos Rios Jaguari e Jacareí & 1977 a 1982 & maio $/ 1982$ \\
\hline
\end{tabular}

Fonte: Sabesp, 2004.

\footnotetext{
${ }^{13} \operatorname{Dos} 33 \mathrm{~m}^{3} / \mathrm{s}, 31 \mathrm{~m}^{3} / \mathrm{s}$ provêm da bacia do rio Piracicaba e $2 \mathrm{~m}^{3} / \mathrm{s}$ da bacia do Rio Juquerí.
} 
Tabela 2.3: Reservatórios, Túneis e Elevatória do Sistema Cantareira

\begin{tabular}{|c|c|c|c|c|c|c|}
\hline $\begin{array}{c}\text { Reservatórios } \\
\text { Túneis e } \\
\text { Elevatória }\end{array}$ & $\begin{array}{c}\text { Altura da } \\
\text { Barragem } \\
\text { (m) }\end{array}$ & $\begin{array}{c}\text { N.A. Máx. } \\
\text { Normal } \\
\text { (m) }\end{array}$ & $\begin{array}{l}\text { Volume } \\
\text { Total } \\
\left(10^{6} \mathrm{~m}^{3}\right)\end{array}$ & $\begin{array}{l}\text { Extensão } \\
\text { do Túnel } \\
(\mathrm{km})\end{array}$ & $\begin{array}{c}\text { Vazão Produzida } \\
\text { em cada } \\
\text { Reservatório } \\
\left(\mathrm{m}^{3} / \mathrm{s}\right)\end{array}$ & $\begin{array}{c}\text { Vazão Total } \\
\text { Disponível } \\
\text { Acumulada } \\
\left(\mathrm{m}^{3} / \mathrm{s}\right)\end{array}$ \\
\hline Jaguari & 55 & 844 & 140 & & 1 & 18 \\
\hline Jacareí & 50 & 844 & 898 & & 4 & 22 \\
\hline Túnel 7 & & & & 6,03 & & \\
\hline $\begin{array}{l}\text { Cachoeira } \\
\text { Túnel } 6\end{array}$ & 40 & 521,7 & 114 & 5,25 & 5 & 27 \\
\hline $\begin{array}{l}\text { Atibainha } \\
\text { Túnel } 5\end{array}$ & 40 & 787 & 229 & 9,84 & 4 & 31 \\
\hline $\begin{array}{l}\text { Paiva Castro } \\
\text { (Juqueri) }\end{array}$ & 22 & 745 & 36 & & 2 & 33 \\
\hline $\begin{array}{l}\text { Túnel } 3 \\
\text { Estação Elevatória } \\
\text { Santa Inês }\end{array}$ & & & & 1 & & \\
\hline Túnel 1 & & & & 0,855 & & \\
\hline Águas Claras & 24 & 859,5 & 1 & & & 33 \\
\hline Túnel 2 & & & & 4,826 & & \\
\hline ETA-Guaraú & & & & & & 33 \\
\hline
\end{tabular}

Fonte: AZEVEDO NETTO et al., 1978.

\section{$2.3 \quad$ O Túnel 2}

O Túnel 2 é um dos sete túneis que compõem o Sistema Cantareira. Escavado em rocha, possui 4.826 m de extensão com seções de diâmetro hidráulico de 4,5 $m$ a 5,5 $m$, faz a ligação entre o Reservatório de Águas Claras e a Estação de Tratamento de Água do Guaraú.

O dimensionamento de galerias escavadas em rocha baseia-se no cálculo da perda de carga $H_{f}$ quando circula a vazão $Q$. Para este cálculo, as fórmulas clássicas permitem determinar a perda de carga com boa aproximação se são conhecidos os valores do diâmetro hidráulico $D_{H}$ e da rugosidade relativa $\epsilon / D_{H}$ da parede da galeria.

Para galerias revestidas, $\epsilon / D_{H}$ é bem determinado, enquanto que para galeria brutas ou parcialmente revestidas, este valor é de difícil estimativa; pode- 


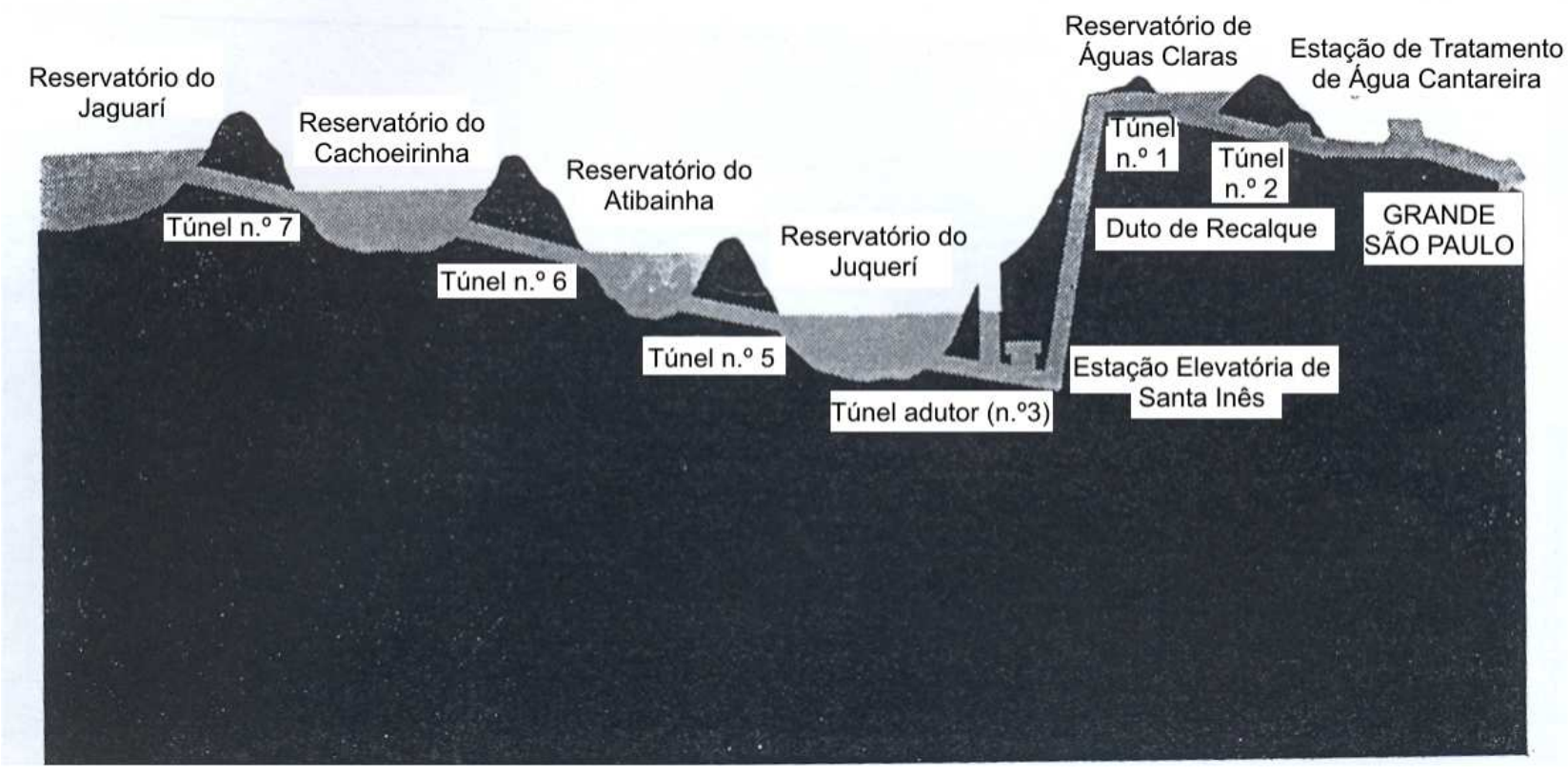

Figura 2.1: Perfil Hidráulico esquemático do Sistema Cantareira - Ilustração de 1970

se apenas obter uma estimativa grosseira de $\epsilon / D_{H}$, o que não garante precisão nos cálculos da perda de carga e, portanto, no dimensionamento da galeria. Assim a tendência é: "adotar freqüentemente como solução uma galeria revestida, de dimensionamento seguro e quando é adotada a solução galeria bruta, há sempre um superdimensionamento oneroso devido aos coeficientes de segurança em jogo" (SANCHEZ, 1971).

O Túnel 2 foi projetado e construído em rocha bruta sem revestimento, para uma vazão de $22 \mathrm{~m}^{3} / \mathrm{s}$, com bases nos estudos realizados até o ano de 1967 , como descrito na seção 2.2. Em 1969, com a conclusão de novos estudos sobre a capacidade do sistema, verificou-se a viabilidade da ampliação da vazão para $33 \mathrm{~m}^{3} / \mathrm{s}$, assim surgiu a necessidade de redimensiornar o Túnel 2, para que este pudesse garantir a vazão dos $11 \mathrm{~m}^{3} / \mathrm{s}$ a mais, além dos $22 \mathrm{~m}^{3} / \mathrm{s}$ que já estavam previstos. A solução encontrada para esse redimensionamento foi a execução de 


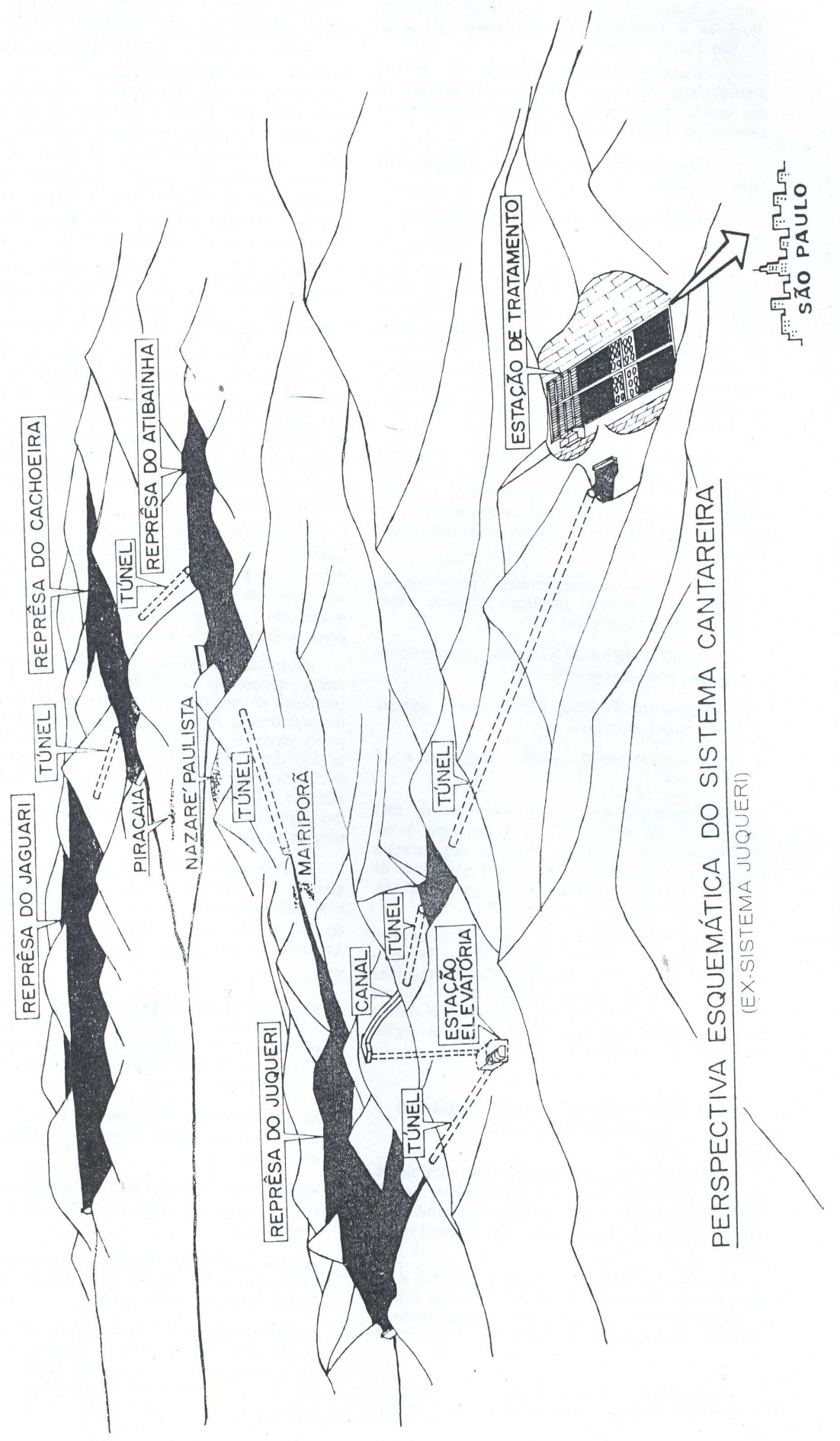

Figura 2.2: Sistema Cantareira - Ilustração de 1970 
um rebaixamento de $2 m$ na bancada do túnel em toda sua extensão.

O projeto inicial da ETA do Guaraú previa um grande reservatório de água tratada no seu pavimento térreo, ficando a ETA propriamente dita, sobre o reservatório. Isto exigia que a cota do piso do Túnel 2, no desemboque, fosse 842,40, e assim foi escavado o túnel, com seção projetada para aduzir $22 \mathrm{~m}^{3} / \mathrm{s}$. Com a mudança do projeto para a ETA, esta passou a ocupar a posição anteriormente destinada ao reservatório de água tratada, como o túnel já estava escavado, resultou em um desnível de 9,70 $\mathrm{m}$. Para a solução do problema, foi estudada a possibilidade de utilizar o desnível para a produção de energia elétrica.

Relatórios da empresa Redaelli (empresa contratada pela COMASP para elaboração dos projetos da hidrelétrica e também para o rebaixamento do túnel), mostraram, inicialmente, que seria economicamente viável a construção da usina hidrelétrica e, para tanto, somado o fato da mudança da vazão, era necessário o cálculo exato da perda de carga no túnel.

Antes do primeiro estudo realizado pela EESC para a previsão das perdas de carga do túnel, a empresa Redaelli Engenharia Ltda apresentou à COMASP o relatório: Mémória de Cálculo da Determinação da Seção do Túnel N² (REDAELLI, 1969a), neste, com base na fórmula de Manning (equação 2.1), foi apresentado o primeiro estudo das perdas de carga com a finalidade de propor o redimensionamento do túnel.

$$
\frac{H_{f}}{l}=\frac{Q^{2}}{A^{2} R_{H}^{4 / 3} M^{2}}
$$


Onde:

- A é a área molhada da seção do túnel;

- $R_{H}$ é o Raio hidráulico;

- $M$ o coeficiente de atrito de Manning;

- $H_{f}$ são as perdas de carga por metro de comprimento do túnel;

- $l$ o comprimento, e

- $Q$ a vazão.

Com base nestes estudos, a Redaelli conclui que a área ótima para o túnel 2, quando utilizado como canal de adução para uma usina hidroelétrica, é da ordem de $30 \mathrm{~m}^{2}$, para tanto, foi sugerido o rebaixamento de $2 m$ da bancada em toda a extensão do túnel e o alargamento de 1,20 m numa extensão de $2500 \mathrm{~m}$, onde a seção do túnel era do tipo 6. A figura 2.3 ilustra como foi projetado o rebaixamento e alargamento para as seções transversais tipo 5 e tipo 6 , a linha tracejada representa o projeto inicial do túnel.

Em março de 1969, foi iniciado o rebaixamento proposto pela Redaelli em duas frentes de trabalho: uma de montante para jusante e a outra no sentido oposto.

Durante as obras de rebaixamento a COMASP resolveu contratar uma consultoria para avaliar a real necessidade do rebaixamento de toda a extensão do túnel, e também para verificar a perda de carga, para o sucesso na implantação da 

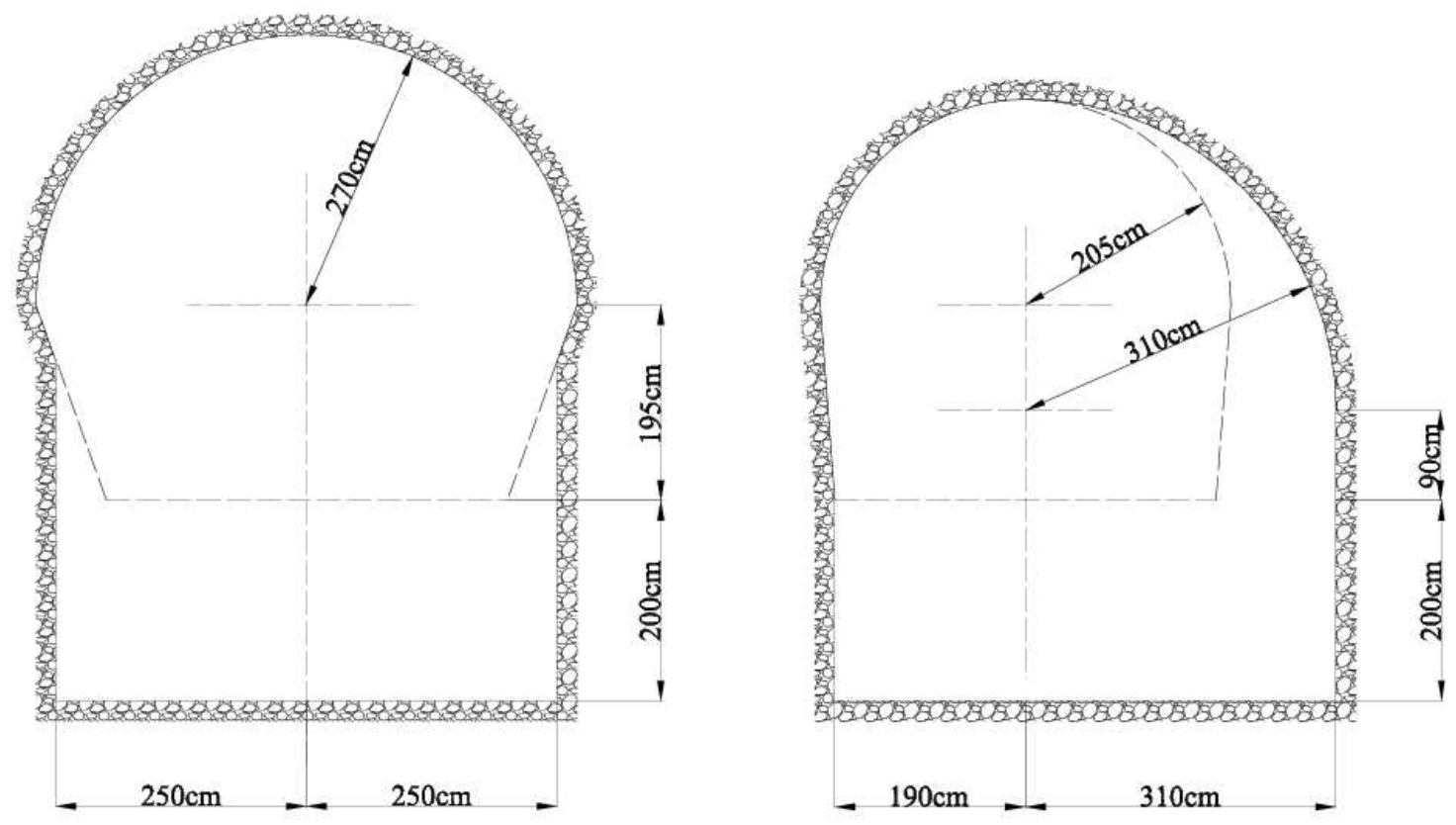

Figura 2.3: Seção tipo 5 e tipo 6

hidrelétrica. Na época, um dos assessores da presidência da COMASP e professor da Escola Politécnica da USP, Tufi Mamed Assy, sugeriu o Prof. Rui Vieira e a ESSC para realizarem tal consultoria. 


\subsection{Departamento de Hidráulica e Saneamento:}

\section{Contribuições à Engenharia no Brasil}

Originado no final do ano de 1969 da fusão das Cátedras de Hidráulica, Saneamento, Mecânica dos Fluidos e parte de Termodinâmica Aplicada - Transmissão de Calor, antiga Física Técnica, o Departamento de Engenharia Hidráulica e Saneamento (SHS), da Escola de Engenharia de São Carlos (EESC), teve como impulsionador do seu processo de implantação e consolidação do SHS, o Professor Ruy Carlos de Camargo Vieira:

... idealista e empreendedor, a marca de seu estilo arrojado impregnou o setor com expressiva parcela representativa de sua forte personalidade. Sua capacidade de realização e amplitude de visão manifesta em vários aspectos de sua administração, que o levaram a contemplar projetos ousados, projetaram-se ao longo de três décadas e propiciaram o engajamento e efetiva contribuição de alguns dos profissionais mais competentes que atuaram no setor (ALTAFIM, 2003).

Entre estes "projetos ousados", estão os Ensaios de Perda de Carga do Túnel 2 realizados nos anos de 1969 e 1972, durante as obras do Sistema Cantareira, para os quais foram necessários o uso de várias técnicas e tecnologias para a confecção e utilização dos equipamentos necessários para a avaliação da vazão do túnel.

A coincidência entre as datas do Ensaio Preliminar e a constituição do SHS tem grande relevância na consolidação deste Departamento como centro de ensino e pesquisa. O mesmo grupo formado para a realização dos ensaios, liderado pelo Prof. Ruy Vieira, constituiu o corpo técnico e docente do novo departamento. 
Além disso, os recursos destinados aos honorários das pessoas envolvidas nos ensaios, foram doados ao departamento, o que possibilitou a construção do prédio Euclides da Cunha, o primeiro edifício destinado a abrigar a administração e salas de professores do SHS.

Um fato importante na história do SHS, foi a visita do Professor Enzo Oscar Macagno, da Iowa State University no final do ano de 1969, o qual apresentou um arrojado projeto, que foi encaminhado à Fundação de Amparo à Pesquisa do Estado de São Paulo (FAPESP) sob o título "Relatório Macagno - Centro Regional de Engenharia Ecológica", dando início à implantação de um complexo de laboratórios à margem da Represa do Lobo. Com recursos do Banco Nacional de Desenvolvimento Econômico (BNDE), no período de 1971 a 1977, foram construídas as primeiras instalações do atual Centro de Recursos Hídricos e Ecologia Aplicada (CRHEA) (ALTAFIM, 2003), com isso iniciaram-se as atividades de pesquisa em recursos hídricos e ecologia, através de convênios com a Organização dos Estados Americanos (OEA) e o Departamento Nacional de Águas e Energia Elétrica (DAEE).

As atividades no campo da pós-graduação iniciaram-se em 1970 com o programa de mestrado e em 1975 com o de doutorado, proporcionando grande avanço na área de pesquisa. O reconhecimento em nível nacional, das pesquisas realizadas pelos alunos e professores dos programas de pós-graduação do SHS, foi alcançado no ano de 1989, quando o programa obteve nível A na avaliação da CAPES, tanto no mestrado quanto no doutorado. No mesmo ano, o SHS criou o programa de pós-graduação em "Ciências da Engenharia Ambiental". 
Segundo Altafim (2003), a atuação e o empenho, do grupo inicialmente liderado pelo Prof. Ruy Vieira, durante a década de oitenta foram decisivos para a consolidação do ensino de pós-graduação e, conseqüentemente, das linhas de pesquisa em Recursos Hídricos e Ecologia Aplicada, bem como daquelas que enfocam o desenvolvimento de tecnologia de controle da qualidade das águas de abastecimento, das águas residuárias e de resíduos sólidos.

O SHS contribuiu decisivamente à caracterização da Área de Engenharia Ambiental no Brasil com a proposta da implantação, no início da década de 1990, da habilitação "Engenharia Ambiental ${ }^{14 "}$ na EESC, que tem servido de base para a criação do curso em outras instituições de ensino superior no país:

A proposta da Escola foi submetida à Comissão de Especialistas de Ensino de Engenharia do MEC, em 1994, e apreciada em diversos fóruns de discussão de coordenadores de cursos da Habilitação Engenharia Sanitária. A partir das discussões ocorridas naquele mesmo ano, o MEC criou a Área de Engenharia Ambiental com currículo mínimo específico, distinto das demais áreas de Engenharia existentes.

(ALTAFIM, 2003).

A proposta apresentada pela EESC tem servido, ainda hoje, como base para reestruturação de programas existentes em outras Instituições de Ensino Superior do País, bem como para elaboração de novos currículos na área de Engenharia Ambiental (ALTAFIM, 2003).

\footnotetext{
${ }^{14}$ Os estudos e propostas para a criação dessa habilitação, tiveram início com a reforma curricular dos Cursos de Engenharia, realizada em meados dos anos setenta, em vista da criação de "currículos mínimos" pelo Conselho Federal de Educação, quando tornou-se obrigatória a oferta da matéria Ciências do Ambiente, nos cursos de Engenharia, ocasionando importantes reflexos no departamento, que recebeu a incumbência de ministrar essa matéria na EESC.
} 


\section{Capítulo 3}

\section{Metodologia}

Os instrumentos utilizados para o desenvolvimento deste estudo são as pesquisas bibliográfica, a documental e a entrevista não estruturada ou informal.

A historiografia de qualquer ramo do conhecimento é primordialmente baseada em pesquisa documental, eventualmente complementada por entrevistas, depoimentos, fotos, etc. Mas, para além do óbvio aproveitamento dos dados explícitos do que constitui o conteúdo dos documentos analisados, a partir deles pode-se chegar a valiosas informações adicionais (CINTRA, 2000).

A pesquisa documental assemelha-se muito à pesquisa bibliográfica. A pesquisa bibliográfica utiliza-se fundamentalmente das contribuições dos diversos autores sobre determinado assunto, enquanto a pesquisa documental utiliza-se de materiais que não receberam tratamento analítico. Assim, as fontes de pesquisa documental são mais diversificadas e dispersas do que as da pesquisa bibliográfica.

Conforme Gil (1991), na pesquisa documental existem os documentos de 
primeira mão, ou seja, aqueles que não receberam nenhum tratamento analítico, tais como os documentos conservados em órgãos públicos e instituições privadas, e os documentos de segunda mão que de alguma forma já foram analisados, tais como: relatórios de pesquisa; relatórios de empresas; tabelas estatísticas e outros.

Segundo o mesmo autor, há vantagens e limitações neste tipo de pesquisa. As vantagens são:

- Os documentos constituem-se em uma fonte rica e estável de dados;

- Baixo custo, pois exige praticamente apenas disponibilidade de tempo do pesquisador;

- Não exige contato com os sujeitos da pesquisa.

Como limitação, as críticas mais freqüentes referem-se à não representatividade e à subjetividade dos dados mas, a análise documental "pode se constituir numa técnica valiosa de abordagem de dados qualitativos, seja complementando as informações obtidas por outras técnicas, seja desvelando aspectos novos de um tema ou problema" (LÜDKE e ANDRÉ, 1986).

Além da pesquisa documental, é utilizado neste trabalho, como fonte de informações, a entrevista não estruturada ou informal. Este tipo de entrevista "só se distingüe da simples conversação porque tem como objetivo básico a coleta de dados", é recomendada "nos estudos exploratórios que visam abordar realidades pouco conhecidas pelo pesquisador ou então oferecer visão aproximativa do problema pesquisado" (GIL, 1991). 
No tocante às entrevistas não estruturadas ou informais, o estudo foi baseado em entrevistas com os professores que participaram dos ensaios do Túnel 2.

Os critérios utilizados para a seleção dos professores para a execução da entrevista não estruturada ou informal foram baseados nas referências aos nomes encontrados nos documentos pesquisados. Também foram consideradas a disponibilidade, o acesso e a facilidade de localização dos mesmos.

\subsection{As Fontes}

A primeira etapa da pesquisa consistiu em encontrar as fontes, e nelas os documentos necessários para a análise. A busca se iniciou no arquivo inativo do SHS e na Biblioteca da EESC.

Nesta primeira etapa não houve preocupação com a análise dos documentos encontrados, apenas com a obtenção das informações advindas de publicações, anais em congressos, revistas, fotos, relatórios, memoriais descritivos e de cálculo, etc. Sempre eram anotadas as fontes e a documentação arquivada, primeiramente, segundo o local onde foi encontrada.

No acervo da Biblioteca Central da EESC não foram encontrados documentos referentes aos ensaios, como se acreditava no inicio das buscas. Mas a biblioteca tornou-se a principal fonte em relação às referências bibliográficas mencionadas nos relatórios quanto aos pressupostos teóricos do ensaio. Sua grande quantidade de periódicos (jornais e revistas) da época e a possibilidade de em- 
préstimos de materiais de acervos de outras bibliotecas foi de fundamental importância nesta fase de coleta dos dados.

Após as primeiras análises dos documentos, passou a ser incluída como fonte de informações o arquivo Técnico da SABESP, empresa que substituiu a antiga COMASP (Companhia Metropolitana de Abastecimento de São Paulo), responsável pelas obras do Sistema Cantareira. Nesta fonte não foi possível um contato direto do pesquisador com os documentos relativos aos ensaios. A seleção do material ficou ao encargo do responsável pelo acervo que separou o material que ele julgou pertinente ao assunto. O pesquisador só teve acesso a esse material após um convênio de sigilo firmado entre a EESC e a SABESP, que estabeleceu que as informações contidas no material emprestado pela SABESP só poderiam ser utilizados para esta pesquisa.

Nem todo o material emprestado através deste convênio pôde ser copiado. Por se tratar de um material com mais de trinta anos, e alguns serem fotocópias e não estarem em um local apropriado (climatizado, com controle de umidade e luminosidade adequada), alguns documentos tiveram de ser digitalizados.

O material coletado nos arquivos do SHS e da SABESP relacionados ao do Túnel 2 constou de 32 relatórios. Destes, apenas 8 relatórios eram sobre os ensaio com escoamento de ar executados pela EESC e 24 de empresas que executaram as obras de redimensionamento ${ }^{1}$ do túnel.

Foram encontradas algumas cartas e ofícios, dos quais foi possível levantar

\footnotetext{
${ }^{1}$ Não se teve acesso a nenhum material sobre o dimensionamento inicial do túnel, apenas aos relativos ao seu redimensionamento.
} 
alguns dados referentes aos primeiros contatos entre a COMASP e a Cátedra de Mecânica dos Fluidos, solicitação de empréstimo de alguns equipamentos relacionados aos ensaios e comunicação entre a COMASP e a EESC de uma forma geral. Estes documentos são indispensáveis para a reconstituição das datas relativas aos ensaios, pois alguns relatórios não possuem nem a data de publicação nem data da realização da atividade a que se refere o relatório.

Foram encontradas nessas fontes diversas fotografias relacionadas aos ensaios e das simulações em laboratório. Estas imagens foram digitalizadas e algumas incorporadas ao texto, as demais estão em um CD que, juntamente com o filme gravado durante os ensaios no túnel, filme este que após passar por um processo de recuperação foi digitalizado para o formato DVD, constituem os anexos deste trabalho.

Após esta primeira etapa de coleta, foram relacionados dois periódicos como fontes bibliográficas: uma revista brasileira, a Revista DAE e a revista francesasa Le Génie Civil.

A revista DAE - Revista do Departamento de Água e Esgoto - editada entre os anos de 1959 e 1994, tornou-se uma importante fonte bibliográfica, pois esta, na época das obras do Sistema Cantareira, era um dos principais canais de divulgação na área de saneamento. Nela foram encontrados diversos artigos sobre o Sistema Cantareira e alguns relacionados aos ensaios. A escolha da revista como fonte, deve-se ao fato desta ser citada em alguns relatórios por ter publicado os anais do V Congresso de Engenharia Sanitária (1969) com os seguintes trabalhos: 
- Diâmetro Hidráulico de seções irregulares. Determinação por Método óptico

- Hans George Arens.

- Determinação da Vazão de água em Túnel por Circulação de Ar. Dimensionamento de Diafragma e seu Modelo Reduzido - Marcius F. Giorgetti, Dante Contin Neto e Reynaldo Gava.

- Determinação da Perda de Carga Hidráulica por circulação de Ar - Manoel Collaço Veras, Milton G. Sanchez e Otávio de Matos Silvares.

A consulta a esta fonte se deu da seguinte forma:

Iniciou-se a busca nas edições publicadas nos anos em que foram realizados os ensaios, depois às edições de cinco anos anteriores ao primeiro ensaio (1969), e cinco anos posteriores ao segundo ensaio (1972). Assim, foram consultadas as edições publicadas entre 1964 e 1977.

A consulta consistiu em procurar no índice de cada edição, artigos relacionados não só aos ensaios, mas ao Sistema Cantareira como um todo, a fim de levantar a maior quantidade possível de dados sobre a obra. Os artigos encontrados eram fotocopiados e arquivados segundo a data de publicação.

A fundamentação teórica utilizada para a elaboração e justificativa do método da circulação de ar teve sua base nos trabalhos de Remenieras e Bourguignon de 1953, publicados pela revista Le Génie Civil nas edições de março, abril, maio e junho. Nestes trabalhos, além da fundamentação teórica, foram relatadas as experiências dos autores com a determinação das perdas de cargas em túneis de usinas hidrelétricas francesas através de escoamento de ar. 


\subsection{Organização do Material e Procedimentos da}

\section{Análise}

Nesta fase do estudo, o material recebeu uma primeira organização, pois era indispensável dispor o conjunto analiticamente e proceder de forma a torná-los inelegíveis segundo os objetivos da dissertação.

Os documentos encontrados foram arquivados em pastas classificadas segundo a data de publicação e assunto. Para os relatórios e memoriais, foram elaboradas fichas de leitura contendo um resumo, referência bibliográfica e tópicos abordados. As cartas, ofícios e memorandos eram classificados por data, remetente e local, procedimento este indispensável para a reconstituição precisa das datas ou períodos em que foram realizadas cada etapa dos ensaios.

Para essa primeira organização, foram elaborados dois quadros: um contendo a relação de relatórios que estavam em condições de serem fotocopiados e outro com a relação dos que tiveram de ser digitalizados. Estes dois quadros permitiram relacionar, além das etapas que se dividiram os ensaios com circulação de ar, outras atividades que influenciaram tanto nas características da galeria (tratamento dado ao maciço em determinados trechos) quanto na justificativa da necessidade dos ensaios.

A cópia e digitalização dos documentos foram necessárias por dois motivos. O primeiro está relacionado com o curto prazo para a permanência do material com o pesquisador, este prazo foi estabelecido pelo convênio de empréstimo firmado entre a SABESB e o SHS. O segundo motivo é que devido às condições de 
conservação do material, a consulta poderia danificar os documentos. A cópia e digitalização do material facilitou a consulta e leitura dos documentos, pois possibilitou que se fizesse nessas cópias as anotações necessárias para a análise.

O objeto de observação do presente estudo são os ensaios para a previsão das perdas de carga do Túnel 2 do Sistema Cantareira, sua elaboração seguiu de acordo com os objetivos específicos:

1. Levantamento das bibliografias que contextualizam as técnicas e tecnologias utilizadas para os ensaios;

2. Descrição dessas técnicas e tecnologias, e

3. Análise, de acordo com os registros documentais e entrevistas, da execução atividades relacionadas aos ensaios. 


\section{Capítulo 4}

\section{As Técnicas e Tecnologias}

\section{Usadas nos Ensaios do Túnel 2}

Os ensaios de perda de carga no Túnel 2 do Sistema Cantareira, constaram da medida da diferença de pressões totais que se estabeleceram entre o emboque e o desemboque da galeria para um escoamento de ar. A partir dos dados obtidos nos ensaios foram estimadas as perdas de carga quando se escoasse água.

Segundo Remenieras e Bourguignon (1953a), a estimativa da perda de carga no escoamento de água, a partir da perda obtida quando do escoamento de ar, baseia-se no fato de que o fator de perda de carga $(\lambda)$, da fórmula universal da perda de carga por unidade de comprimento (equação 4.1), para um mesmo número de Reynolds do escoamento em uma canalização de um fluido incompressível em regime permanente, independe da natureza do fluido que escoa (água ou ar no escoamento incompressível ${ }^{1}$ ).

\footnotetext{
${ }^{1}$ Nas condições em que os ensaios foram realizados, o escoamento de ar é considerado in-
} 


$$
J=\frac{\lambda}{D} \frac{V^{2}}{2 g}
$$

Na equação (4.1) $J$ é a perda de carga por unidade de comprimento; $D$ o diâmetro hidráulico da canalização; $V$ a velocidade média do fluido; $g$ a aceleração da gravidade; $\lambda$ é o coeficiente de perda de carga que é uma função do número de Reynolds do escoamento $\left(\operatorname{Rey}=\frac{V D}{\nu}\right)$ e da rugosidade relativa $\epsilon / D$ da parede ( $\nu$ é a viscosidade cinemática do fluido).

$$
\lambda=\varphi\left(R e y, \frac{\epsilon}{D}\right)
$$

em que $\epsilon$ é o parâmetro que caracteriza a rugosidade absoluta da parede.

As pesquisas teóricas e experimentais sobre a perda de carga se reduzem à determinação da função (4.2). Assim se destacam os trabalhos de Nikuradse no estudo da perda de carga em canalizações com rugosidade uniforme e os trabalhos de Colebrook e White que repetiram as experiências de Nikuradse para uma distribuição não uniforme da rugosidade da parede.

A partir dos trabalhos de Nikuradse, Colebrook e White, Von Kárman e Moody construiram ábacos, como o da figura (4.1), que fornecem os valores de $\lambda$ em função do número de Reynolds para uma dada relação $\epsilon / D$.

Com base na figura (4.1), pode-se afirmar que o valor de $\lambda$ para a medida da perda de carga através de uma canalização percorrida por ar, não será igual compressível devido às baixas velocidades, inferiores a um quarto da velocidade do som. 


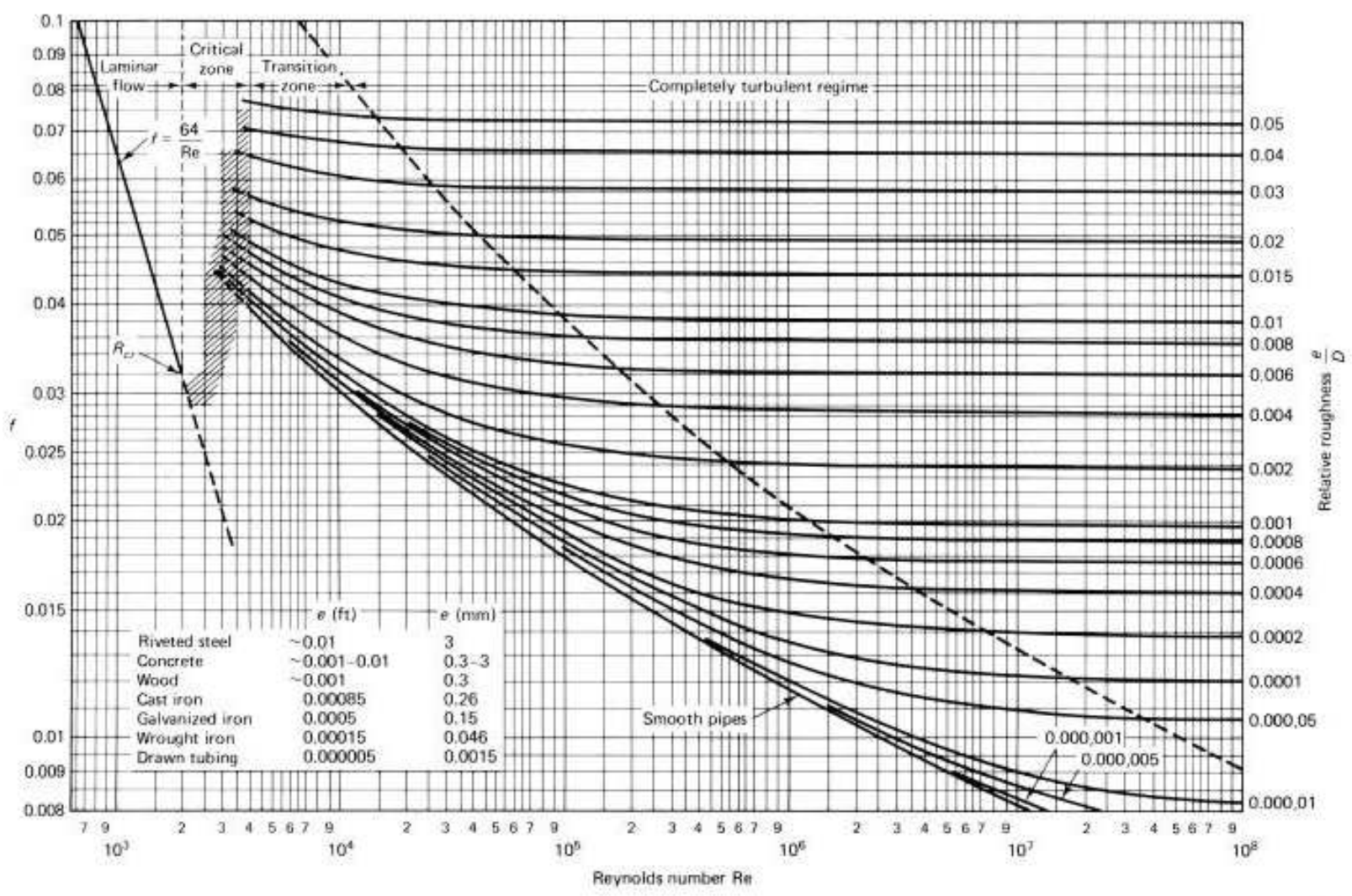

Figura 4.1: Diagrama de Moody (L. F. Moody, Trans. ASME, vol. 66, 1944)

àquele referente à mesma canalização atravessada por água, qualquer que seja o regime destes dois escoamentos (laminar ou turbulento), a não ser que o número de Reynolds seja igual.

Para se obter a igualdade do número de Reynolds exige-se para o escoamento de ar uma velocidade de 10 a 15 vezes superior às velocidades previstas para a água, pois a relação entre a viscosidade cinemática $(\nu)$ do ar e da água é aproximadamente igual a 15. 
Viscosidade Cinemática $\nu\left(\mathrm{m}^{2} / \mathrm{s}\right)$

a $15^{\circ} \mathrm{C}$ e a pressão de $760 \mathrm{~mm} \mathrm{Hg}$

\begin{tabular}{ll}
\hline $\mathrm{Ar}$ & $14,7 \times 10^{-6}$ \\
Água & $1,15 \times 10^{-6}$ \\
\hline
\end{tabular}

Fonte: Perrless, 1967.

Em galerias brutas o escoamento se dá no regime turbulento rugoso, como pode ser observado no diagrama de Moody, figura (4.1), este tipo de escoamento está na região em que $\lambda$ só depende da relação $\epsilon / D$, logo para se obter a igualdade de $\lambda$ basta que o escoamento de ar alcance um número de Reynolds superior ao valor crítico $\left(R e y_{c}^{\prime}\right)$ (REMENIÉRAS e BOURGUIGNON, 1953a), calculado pela fórmula proposta por Moody (1944):

$$
\operatorname{Rey}_{c}^{\prime}=\frac{200}{\sqrt{\lambda}} \frac{D}{\epsilon}
$$

Para galerias brutas (REMENIÉRAS e BOURGUIGNON, 1953b), temos $\epsilon=0,10 m$ e $\lambda=0,08$, assim

$$
R e y_{c}^{\prime}=7060 D
$$

Esta condição para o número de Reynolds permitiu que na realização do ensaio fosse utilizado um sistema de ventilação de porte inferior ao que seria necessário se fosse observada a igualdade no número de Reynolds.

O valor de $\lambda$ para o escoamento de água nesse tipo de galeria é diferente 
do valor de $\lambda$ para o escoamento de ar, mas a partir dele pode-se determinar, por extrapolação, o valor de $\lambda$ para o escoamento de água, através dos diagramas de Nikuradse, de Colebrook ou de Moody-Rouse.

\subsection{Determinação das perdas de carga}

A instalação necessária para obter a previsão das perdas de carga na vazão de água, a partir dos dados de um ensaio com circulação de ar, constou de:

- Conjunto de ventiladores axiais para fornecer a vazão de ar;

- Estação medidora da vazão;

- Medidores de pressão estática ao longo do túnel;

- Sistema de telecomunicação.

Para a aplicação desta técnica é necessário que a distância entre duas seções consecutivas medidoras da pressão estática seja suficiente para assegurar a precisão requerida pelo ensaio. Segundo Remenieras e Bourguignon (1953b), a perda de carga mínima $\left(\xi_{m}\right)$ que pode ser medida dentro da precisão desejada, a distância mínima $\left(l_{m}\right)$ entre os medidores e a velocidade $(V)$ do escoamento estão relacionadas pela lei universal da perda de carga

$$
\xi_{m}=1,15 \lambda \frac{l_{m}}{D} \frac{V^{2}}{2 g}
$$

para $\xi_{m}$, expressa em milímetros de coluna d'água. 
Devido às características do Túnel 2 e a precisão imposta aos resultados e a equação (4.5), para a realização do Ensaio Preliminar (1969), a execução da medida da perda de carga ao longo da galeria, foi prevista em três trechos

- Trecho rebaixado de montante;

- Bancada;

- Trecho rebaixado de jusante.

Considerando-se as dificuldades inerentes à própria medida da pressão durante o ensaio, como por exemplo o tempo de resposta devido às dimensões das tubulações manométricas, a medida da perda ao longo da bancada foi realizada em dois trechos consecutivos. Assim, o túnel ficou dividido em quatro trechos (figura5.1).

De acordo com o relatório Ensaio do Túnel $N^{o}$.2: Pré-Determinação da Perda de Carga no Escoamento de Água por Circulação de Ar (SILVARES, 1969), para o ensaio preliminar, estariam à disposição da COMASP, dois ventiladores com as seguintes características: $\Delta p=40 \mathrm{~mm}$ de coluna d'água e vazão $Q=23,5$ $m^{3} / s$, podendo assim manter a perda total ao longo do túnel, incluindo a perda no estrangulamento devido ao diafragma, igual a $40 \mathrm{~mm}$ de coluna d'água.

Assim, com a possibilidade do uso dos ventiladores descritos acima, a precisão da medida da perda de carga foi fixada em 1\%. Com essa precisão e com a utilização de micronamômetros inclinados, com precisão de 0,1 $\mathrm{mm}$ de coluna d'água, era necessário que houvesse uma perda de pelo menos $10 \mathrm{~mm}$ de coluna d'água em cada trecho. A perda imposta ao diafragma foi de $8 \mathrm{~mm}$. 
Com esses dados e mais as características das seções do túnel apresentadas em relatórios da empresa Redaelli (tabela 4.1), foi estimada a vazão necessária para garantir a perda de $32 \mathrm{~mm}$ ao longo do túnel e de $8 \mathrm{~mm}$ no diafragma, em uma faixa entre $35 \mathrm{~m}^{3} / \mathrm{s}$ e $40 \mathrm{~m}^{3} / \mathrm{s}$.

Tabela 4.1: Características das principais seções do Túnel 2

\begin{tabular}{clc}
\hline Seção & \multicolumn{1}{c}{ Características } & Extensão \\
\hline Tipo 1 & $\begin{array}{l}\text { Capelinha com diâmetro hidráulico } \\
\text { de } 4,51 \mathrm{~m} \text {, revestido em concreto }\end{array}$ & $500 \mathrm{~m}$ \\
Tipo 5 & $\begin{array}{l}\text { Capelinha com diâmetro hidráulico } \\
\text { de } 4,85 \mathrm{~m} \text {, sem revestimento }\end{array}$ & $2500 \mathrm{~m}$ \\
Tipo 6 & $\begin{array}{l}\text { Ferradura, com diâmetro hidráulico } \\
\text { de } 5,5 \mathrm{~m} \text { sem revestimento }\end{array}$ & $1650 \mathrm{~m}$ \\
\hline Fonte: & Redaelli $(1969 \mathrm{~b})$
\end{tabular}

Segundo essas informações, o trecho do túnel com menor número de Reynolds é o trecho em ferradura (Tipo 6), assim, para a vazão de $33 \mathrm{~m}^{3} / \mathrm{s}$ de água tem-se:

$$
R e y=\frac{V D_{h}}{\nu}=\frac{Q D_{h}}{S \nu}
$$

sendo $D_{h}=5,5 \mathrm{~m}$ e a área da seção transversal $S=25 \mathrm{~m}^{2}$, tem-se:

$$
\text { Rey }=\frac{33 \cdot 5,5}{25 \cdot 1,15 \times 10^{-6}}=6,31 \times 10^{6}
$$

Para o escoamento de ar ser semelhante, deveria ser estabelecido com o mesmo número de Reynolds. Porém, como foi visto acima, é suficiente que o valor do número de Reynolds seja superior a um valor crítico, que para essa seção é:

$$
R e y_{c}=7060 D=38800
$$


Considerando-se a instalação dos dois ventiladores, ter-se-ia uma vazão de $47 \mathrm{~m}^{3} / \mathrm{s}$, com a velocidade na seção de maior diâmetro hidráulico, isto é $5,5 \mathrm{~m}$, de $1,88 \mathrm{~m} / \mathrm{s}$, o que daria um número de Reynolds Rey $=7,04 \times 10^{6}$, ou seja, $R e y>R e y_{c}$. Assim, o uso dos dois ventiladores garantiria a condição imposta pelo número de Reynolds.

\subsubsection{Circulação de Ar}

Para a realizaçao do Ensaio Preliminar estava prevista a utilização de dois ventiladores com vazão de $23 \mathrm{~m}^{3} / \mathrm{s}, 50 \mathrm{HP}$ de potência e rotação de $1710 \mathrm{rpm}$, que forneceriam, quando ligados em paralelo, uma vazão de $47 \mathrm{~m}^{3} / \mathrm{s}$. Estes ventiladores seriam emprestado à COMASP por uma outra empresa. Foi com essa hipótese que o ensaio foi projetado.

O empréstimo dos ventiladores não foi possível. Mas como já havia sido realizada uma cotação de preço dos equipamentos, prevendo essa impossibilidade, a COMASP adquiriu três ventiladores com as seguintes características: vazão de $25 \mathrm{~m}^{3} / \mathrm{s}$ cada, sob uma altura manométrica estática de $40 \mathrm{~m}$ de coluna de ar, a $25^{\circ} \mathrm{C}$ e a uma pressão barométrica de $690 \mathrm{~mm}$.

A aquisição dos ventiladores aconteceu poucos dias antes do ensaio, não havendo tempo hábil para verificar, através de ensaio, se os ventiladores forneceriam a vazão apresentada pelo fabricante; isso fez com que as adaptações do projeto do ensaio do Túnel 2 se baseassem apenas nesses dados.

Tanto no Ensaio Preliminar quanto no Segundo, os ventiladores foram fix- 
ados no desemboque do túnel e funcionaram como exaustores (figuras 4.2, 4.3 e 4.4). A escolha da seção para instalação foi auxiliada pelo método óptico desenvolvido por docentes do SHS. No Ensaio Preliminar, figura 4.2, os ventiladores foram instalados na cota zero, pois era o único trecho de desemboque que estava revestido, o que facilitou a montagem dos equipamentos. No Segundo Ensaio, eles foram instalados na progressiva $8 \mathrm{~m}$, com referência o desemboque. Nesta progressiva a seção é retangular com dimensões de 4,20 $m$ de largura e com 3,78 $m$ de altura, o que possibilitou a execução de uma passagem e permitiu livre acesso ao interior do túnel (figuras 4.3 e 4.4).

No relatório intitulado Ensaio Preliminar do Túnel No.2 (SHS, 1969a), observa-se que a ordem de grandeza da vazão ficou muito aquém da prevista com a curva característica dos ventiladores e a projetada para o ensaio. Os ventiladores forneceram uma vazão que variou entre 20 e $27 \mathrm{~m}^{3} / \mathrm{s}$, quando o previsto era de 20 a $70 \mathrm{~m}^{3} / \mathrm{s}$. Esse fato influenciou diretamente a ordem de grandeza das diferenças de pressões, mas segundo o mesmo relatório, os resultados foram satisfatórios. A precisão variou do valor mínimo de 1,8\% ao valor máximo de 10,8\%, ou seja, cinco vezes superiores à expectativa. Com o uso de ventiladores adequados, dentro das especificações estabelecidas, o intervalo de variação da precisão das medidas ficaria entre 0,2 e $2 \%$.

Com adaptações no sistema de medição instalado no túnel, nas imediações do desemboque, foi possível levantar, aproximadamente, a curva característica dos ventiladores através da diferença de pressões entre a seção interna do túnel e a pressão atmosférica a jusante, para as vazões de um, dois e três ventiladores 


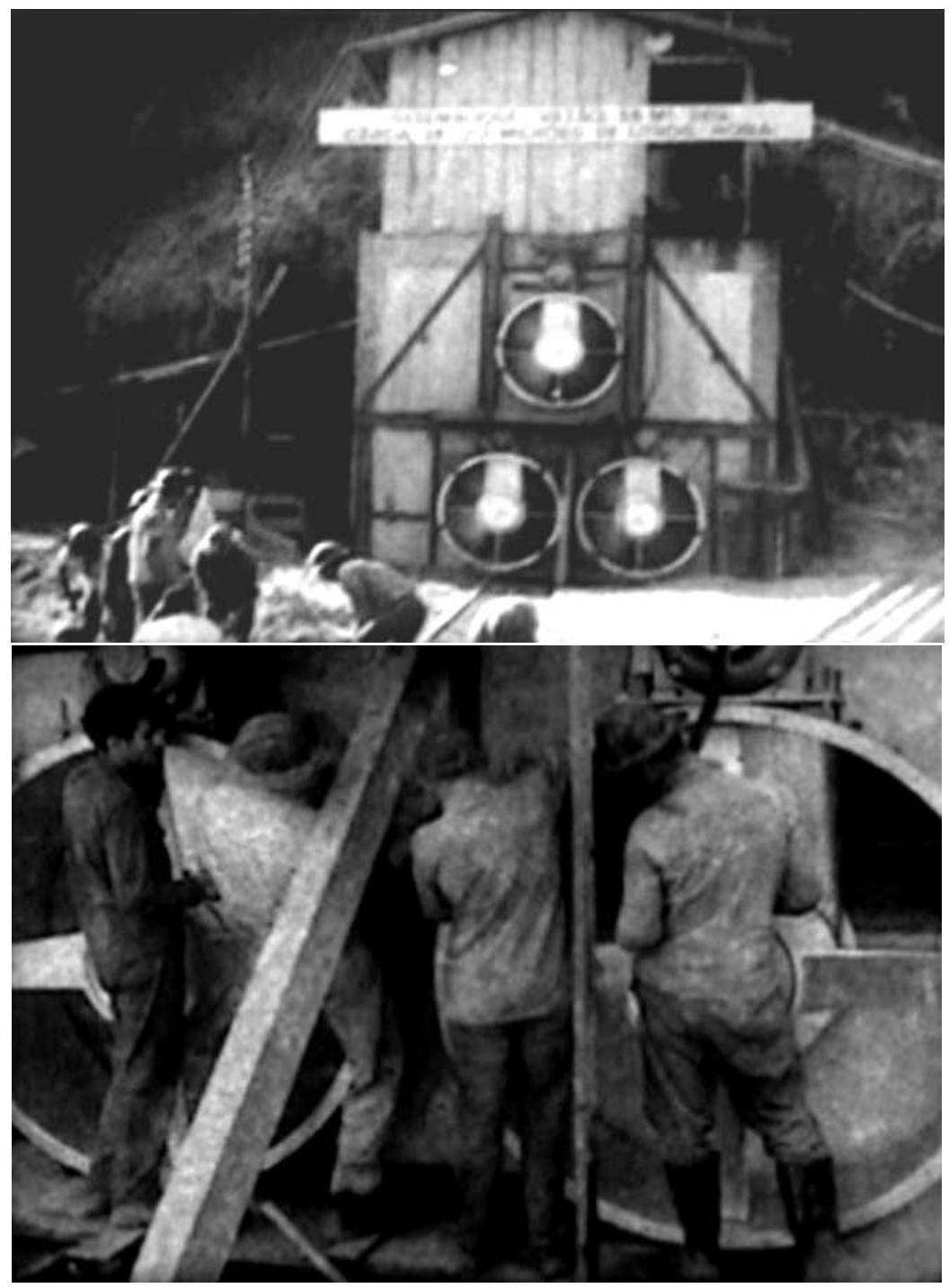

Figura 4.2: Instalação dos Ventiladores - Ensaio Preliminar

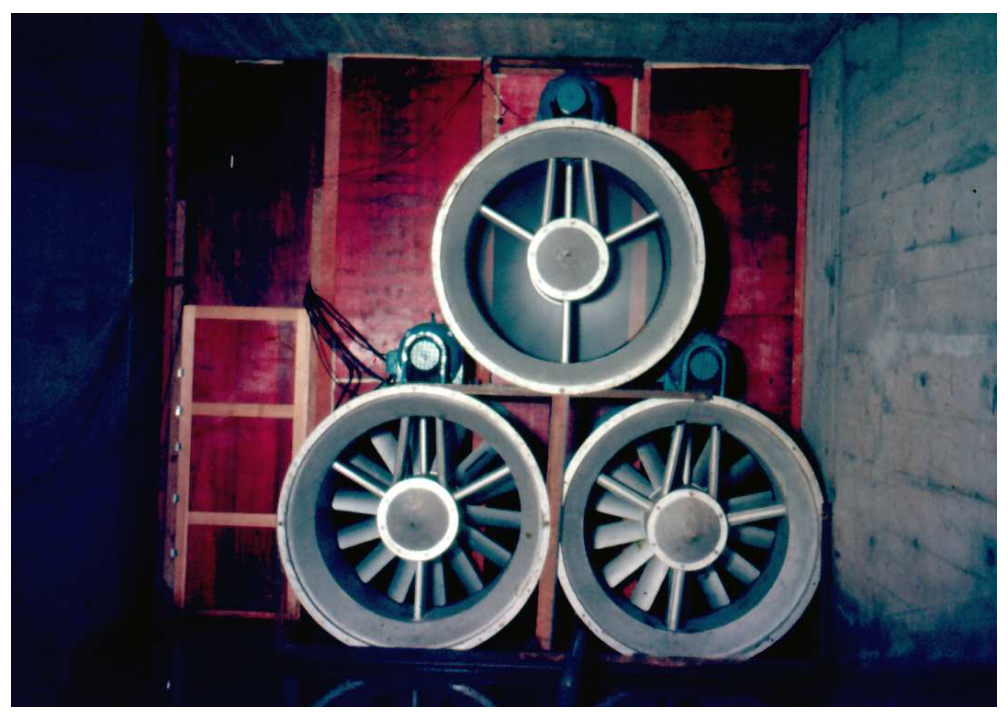

Figura 4.3: Montagem dos ventiladores - vista do interior - Segundo Ensaio 


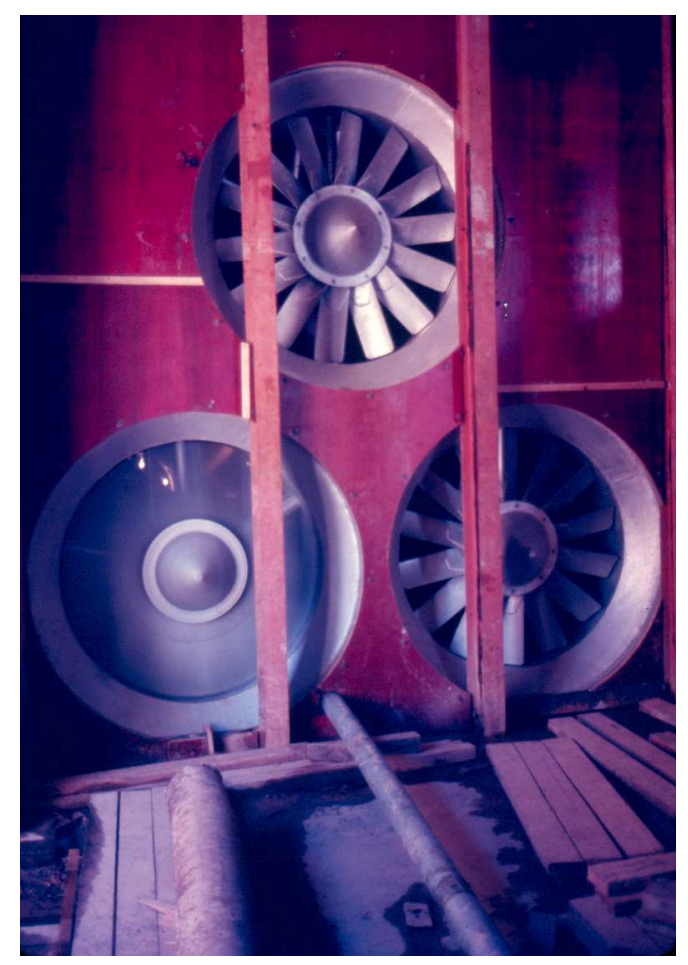

Figura 4.4: Montagem dos ventiladores - vista externa - Segundo Ensaio

ligados simultaneamente, com isso obtiveram-se três pontos de funcionamento distintos. A partir da vazão de um só ventilador, construiu-se o gráfico da variação da altura manométrica em função da vazão. A figura (4.5) apresenta a comparação entre curva apresentada pelo fabricante dos ventiladores e a curva obtida durante o ensaio.

Para a realização do Segundo Ensaio do Túnel 2 (1972), um dos ventiladores usados para a circulação de ar foi ensaiado nos laboratórios do SHS. O ensaio do ventilador teve como finalidade comprovar se no túnel seria obtida a vazão de ar dentro dos limites previstos e evitar problemas como os que ocorreram durante o Ensaio Preliminar, quando os ventiladores não forneceram as vazões previstas.

Devido à inexistência de normas brasileiras na época, o ensaio do ven- 


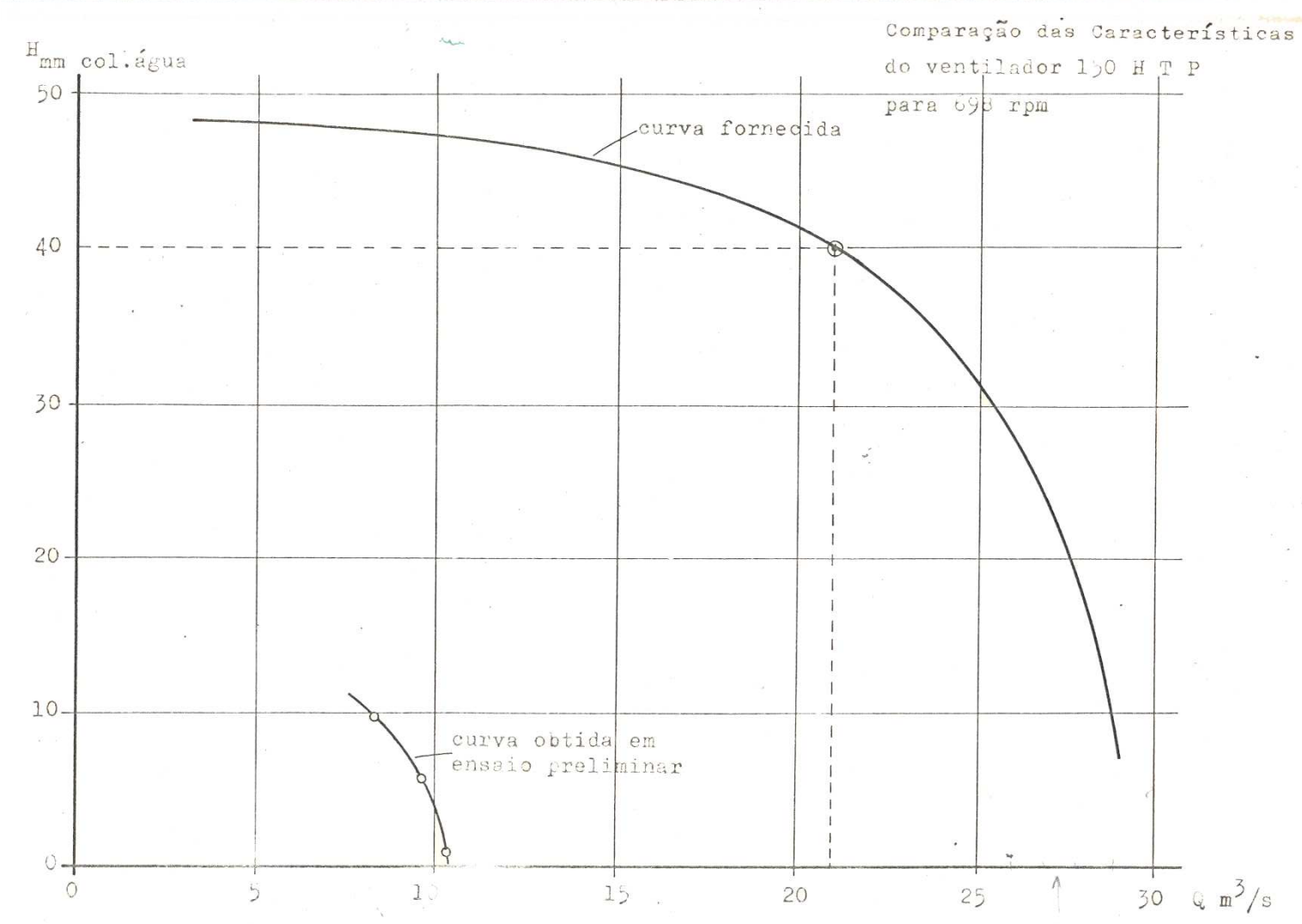

Figura 4.5: Comparação entre a curva característica do ventilador fornecida pelo fabricante e a obtida no ensaio (SHS, 1969).

tilador obedeceu à norma "Power Test Codes, Test Code for Fans" (1970) da American Society of Mechanical Engineers - ASME. Com este ensaio foi obtida a curva característica de pressão total em função da vazão com o controle da ordem de grandeza da potência elétrica absorvida. A rotação de ensaio do ventilador foi mantida constante durante todo o ensaio, e quando instalados no túnel, para levantamento da curva geral de perda de carga, os três ventiladores trabalharam nas mesmas condições do ventilador ensaiado, 925 rpm. No túnel não foi necessária a alteração da rotação dos ventiladores, pois foram atingidas vazões superiores à vazão de projeto.

No túnel, com o uso combinado dos ventiladores, foram obtidas as difer- 

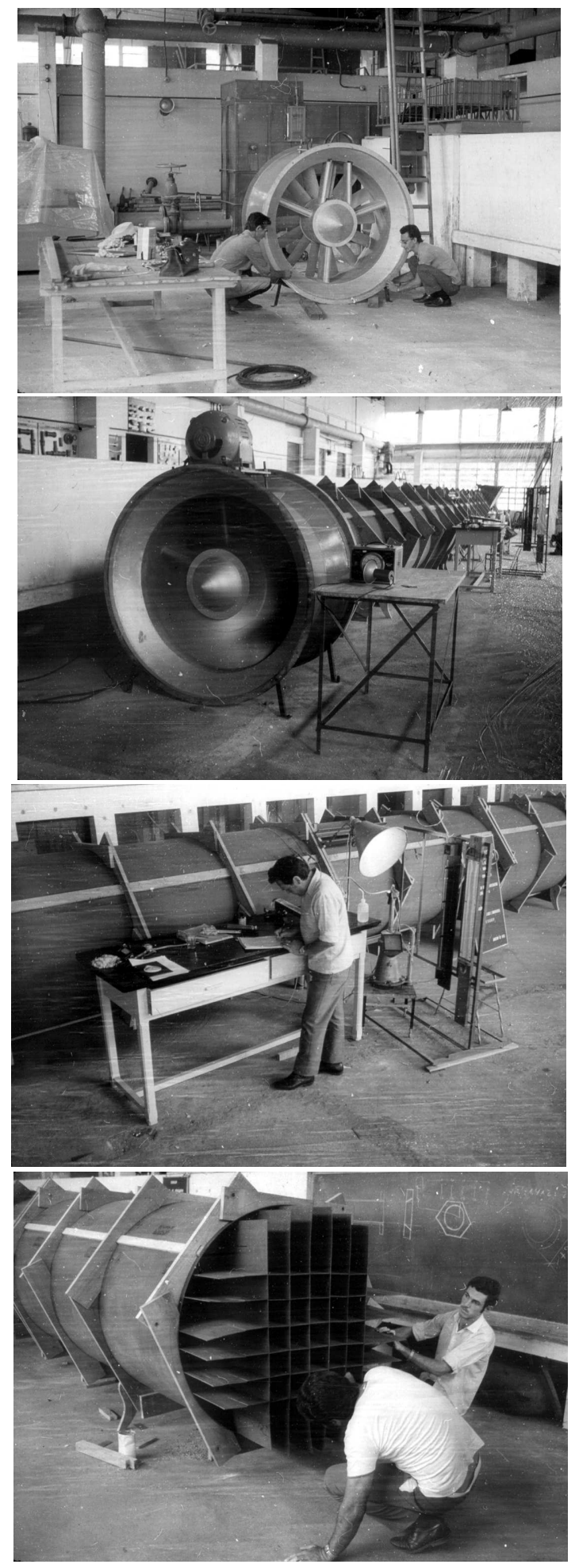

Figura 4.6: Ensaio do Ventilador - 1972 


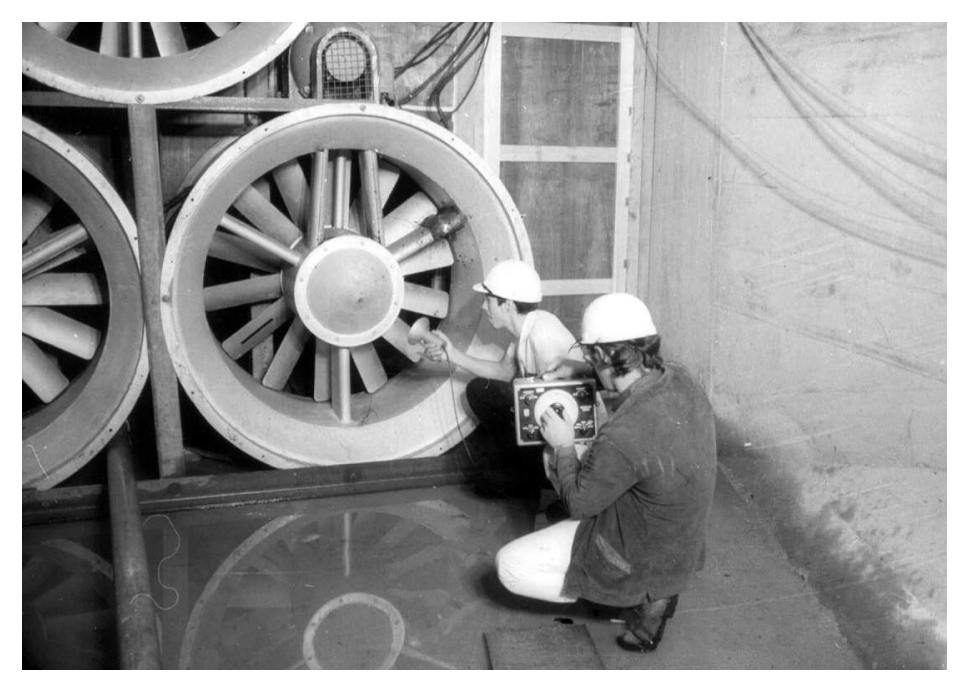

Figura 4.7: Verificação da rotação dos ventiladores com o uso de um estroboscópio

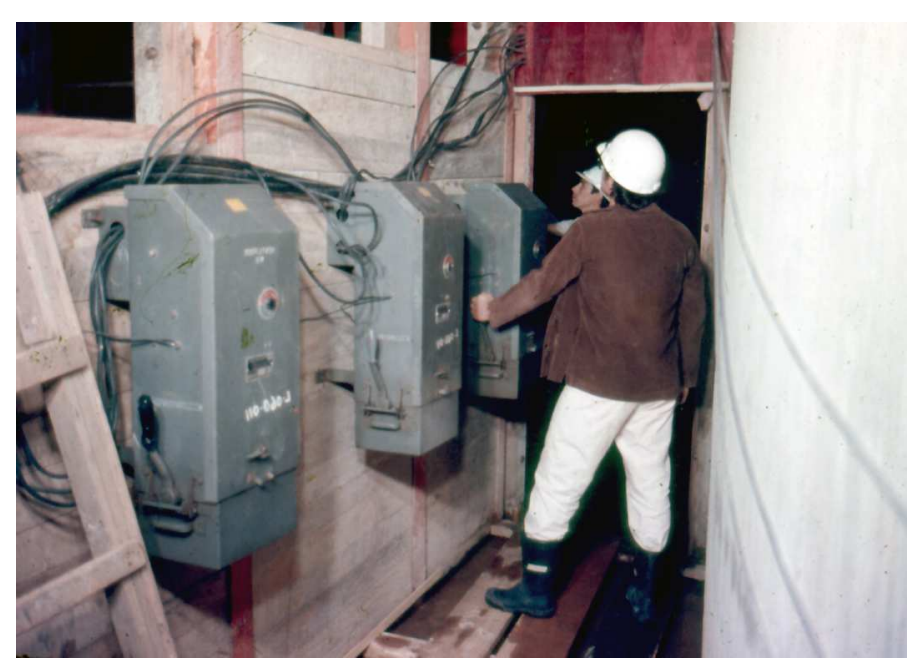

Figura 4.8: Central de acionamento dos ventiladores

entes vazões necessárias para o levantamento dos pontos da curva de perda de carga. Duas flanges cegas de madeira foram executadas e ajustadas aos ventiladores 1 e 2 e uma terceira tampa de área variável ao ventilador 3, de modo a obter, por exemplo, a vazão de 1 e $1 / 2$ ventiladores. Dessa forma foi possível obter vazões abaixo da vazão máxima obtida com os três ventiladores trabalhando-se em plena abertura. 


\subsubsection{Medidor da Vazão}

A medida precisa da vazão de ar foi indispensável para o estabelecimento das condições de semelhança necessária à previsão da perda de carga no escoamento de água.

Para os ensaios realizados no Túnel 2, foi considerada como solução mais viável a medida da vazão com orifício calibrado, no caso um diafragma, devido às grandes facilidades de construção e de medida que ele proporciona ${ }^{2}$. Outra vantagem inerente ao medidor do tipo de orifício é que a vazão pode ser imediatamente estimada, permitindo que a qualidade do ensaio fosse constantemente avaliada (SHS, 1972). Quanto à precisão, para qualquer diafragma, independente da geometria da seção onde é instalado, pode-se sempre obter sua curva de calibração fazendo-se uso de modelos reduzidos ensaiados em laboratório, atingindose dessa forma resultados bastante satisfatórios.

Outra alternativa estudada para a medida da vazão foi a da utilização de um dispositivo convergente e baterias de medidores de velocidade. Nesse caso o dispositivo convergente poderia ser tronco-cônico, ou ter outro formato mais adequado para melhor uniformizar o escoamento na seção contraída.

Na seção contraída seriam instalados tubos de Pitot ou de Prandtl de forma a permitir a leitura em diversos diâmetros da seção. O número de tubos seria determinado a partir do diâmetro fixado para a seção de contração convergente, obedecendo às indicações das normas de medida de vazão em tubulações.

\footnotetext{
${ }^{2}$ Comparado com a utilização de uma bateria de tubos de Prandtl, tem-se a proporção de uma medida para o diafragma contra 25 para os tubos de Prandtl.
} 
A desvantagem desse método é que ele exigiria a construção do dispositivo tronco-cônico, ou equivalente, de grandes dimensões, com dificuldades de transporte e instalação no interior do túnel, bem como a execução de um grande número de medidas de velocidade para a obtenção da vazão. Como conseqüência, a determinação da vazão tomaria muito tempo e demandaria um número grande de operações.

\section{Ensaio Preliminar}

Para o projeto do diafragma utilizado no Ensaio preliminar, foi considerada a possibilidade da utilização de dois ventiladores com vazão de $23 \mathrm{~m}^{3} / \mathrm{s}$ cada, assim foi estabelecida uma perda de $8 \mathrm{~mm}$ de coluna d'água ${ }^{3}$ no diafragma. Como a perda total ao longo do túnel foi estimada em $40 \mathrm{~mm}$ de coluna d'água, restava estabelecer qual seria a vazão necessária para dar a perda de carga de $32 \mathrm{~mm}$ de coluna d'água restantes. Para tanto, adotou-se o valor médio do coeficiente de perdas igual a 0,08 , tendo com base os valores experimentais obtidos por Remenieras e Bourguignon (1953), e considerou-se o túnel dividido em dois trechos - o rebaixado e o não rebaixado - com comprimentos iguais e áreas hidráulicas iguais a $18,5 \mathrm{~m}^{2}$ e $25,0 \mathrm{~m}^{2}$ respectivamente, segundo as informações encontradas em Redaelli (1969b). Assim, para garantir a perda de $32 \mathrm{~mm}$ de coluna d'água no túnel, foi obtida, teoricamente, uma vazão de $57,7 \mathrm{~m}^{3} / \mathrm{s}$.

\footnotetext{
${ }^{3}$ A perda de $8 \mathrm{~mm}$ d'água imposta no diafragma corresponde a um desnível manométrico da ordem de $15 \mathrm{~mm}$, bastante razoável para ser medido com o micronamômetro óptico tipo Betz, com precisão de $1 / 20 \mathrm{~mm}$ de coluna d'água, utilizado para a medida no diafragma. Isso garantiu uma precisão de cerca de $0,3 \%$ na leitura do desnível manométrico para a determinação da vazão mediante o diafragma.
} 
No Ensaio Preliminar, com os resultados obtidos através do método óptico, foi verificado que a melhor seção para instalação do diafragma seria no trecho revestido do início do túnel a montante ${ }^{4}$, cuja área da seção transversal era igual a 18,1 $m^{2}$ (REDAELLI, 1969b), assim a velocidade nessa seção, para a vazão de $57,7 \mathrm{~m}^{3} / \mathrm{s}$, era de $3,19 \mathrm{~m} / \mathrm{s}$. Isso posto, para a perda de $8 \mathrm{~mm}$ de coluna d'água e vazão de $57,7 \mathrm{~m}^{3} / \mathrm{s}$ foi realizado o projeto do diafragma. Como a perda de carga localizada em um estrangulamento é dada pela equação (4.9), e considerando a variação do coeficiente de contração em função da relação de áreas dada por Forchheimer $^{5}$ (1935), foi obtido o diâmetro mínimo ${ }^{6}$ de 2,62 $m$ para o diafragma.

$$
\Delta p=\frac{V^{2}}{2 g}\left(\frac{A}{m C_{c}}-1\right)^{2}
$$

$C_{c}$ é o coeficiente de contração da veia e $m$ a relação de áreas.

O aro do diafragma foi executado na carpintaria da EESC, com cambotas de cedro colocadas escalonadamente para evitar o movimento da madeira.

Para a calibração do orifício ${ }^{7}$, foi construído um modelo reduzido do diafragma e dos trechos do túnel a montante e a jusante dele, à escala de 1:22, e ensaiado nos laboratórios da EESC.

A execução do modelo reduzido utilizou-se do levantamento realizado pelo Método Óptico das seções transversais ao longo das progressivas de montante no

\footnotetext{
${ }^{4}$ No capítulo 5 é apresentado nas figuras (5.1) e (5.3) os esquemas das instalações utilizadas para a medição das perdas no Túnel 2 no Ensaio Preliminar e no Segundo Ensaio.

${ }^{5}$ Forchheimer, Philipp. Tratado de hidráulica. Editorial Labor S.A, 1935.

${ }^{6}$ Qualquer diâmetro superior a $2,62 \mathrm{~m}$ para o orifício do diafragma garantiria a condição da perda localizada não exceder a $8 \mathrm{~mm}$ de coluna d'água.

${ }^{7}$ No Ensaio Preliminar o diafragma foi instalado na progressiva 45 com referência o emboque (figura 5.1).
} 


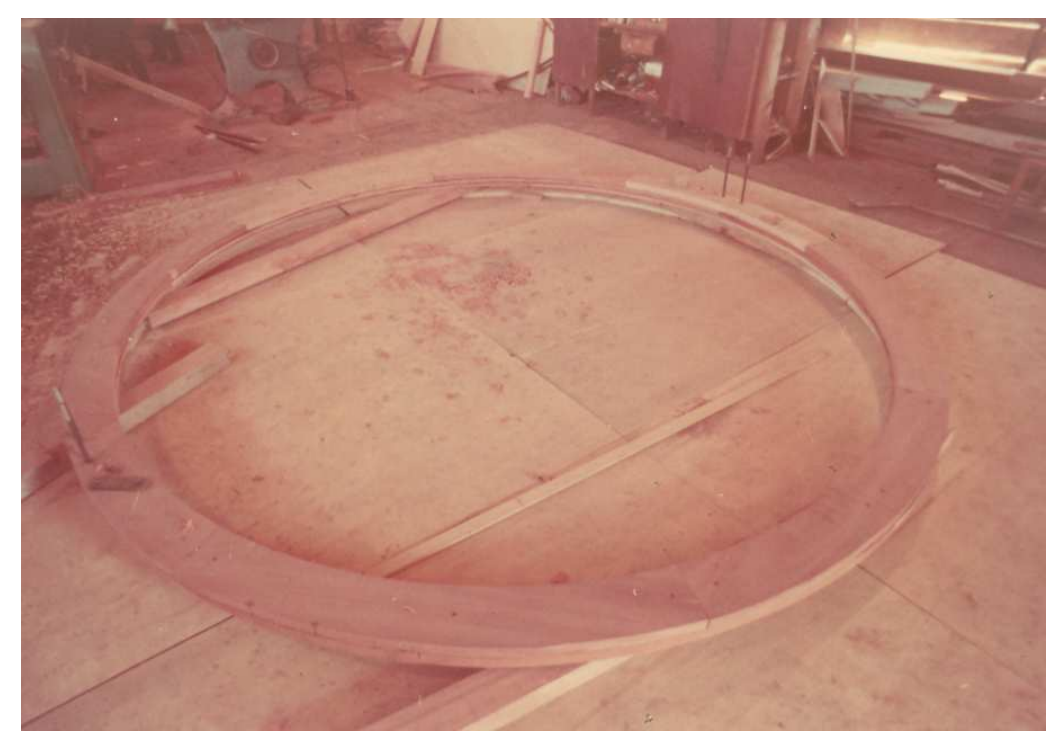

Figura 4.9: Execução do diafragma em cambotas de cedro

trecho revestido. Foi construído um molde de madeira reproduzindo o levantamento das progressivas no trecho em interesse, e sobre ele modelou-se com gesso a reprodução do túnel (figuras 4.14 e 4.15).

O modelo reduzido do diafragma foi construído em chapa de alumínio. Foi colocada ao longo de cada face do diafragma a tubulação de tomada de pressão com os orifícios de medida localizados nas extremidades de dois diâmetros ortogonais inclinados de $45^{\circ}$ relativamente à vertical.

A vazão através do modelo foi medida com a integração de perfis de velocidade num bocal bastante convergente após uma câmara de tranquilização. Para tanto, foi utilizado um tubo de Pitot com deslocamento ao longo do diâmetro de saída do bocal localizado após a câmara de tranquilização. A integração dos perfis de velocidade foi então comparada com a medida da vazão calculada através de um diafragma padrão devidamente calibrado, localizado num trecho de seção circular, inserido com as devidas precauções entre o modelo e o ventilador. Como 


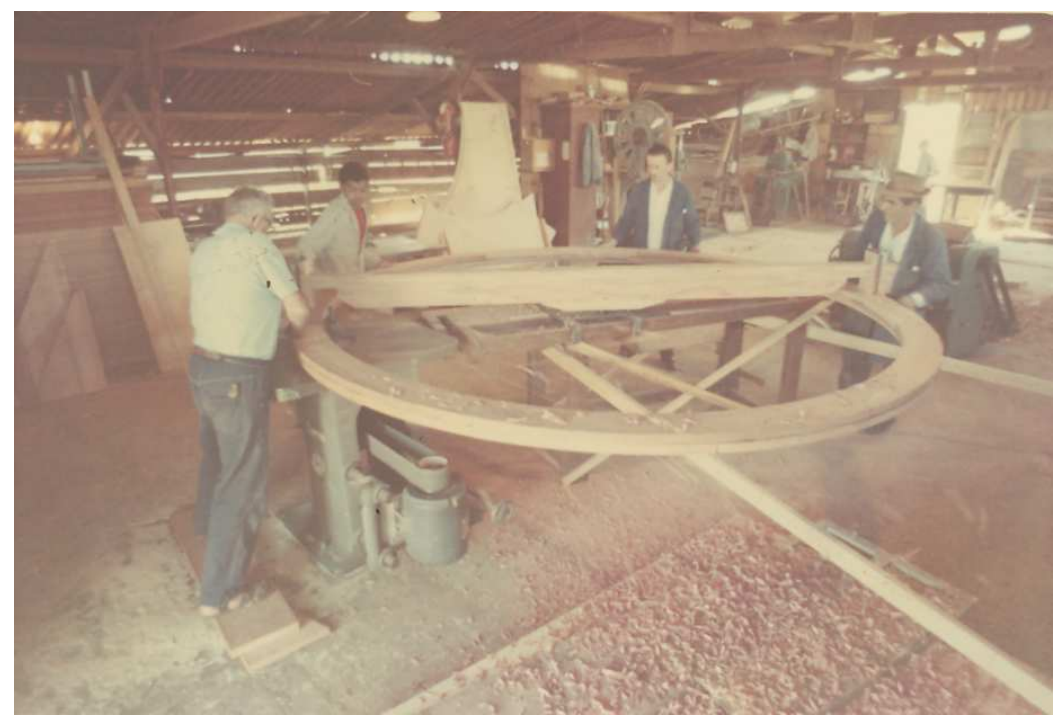

Figura 4.10: Execução do diafragma

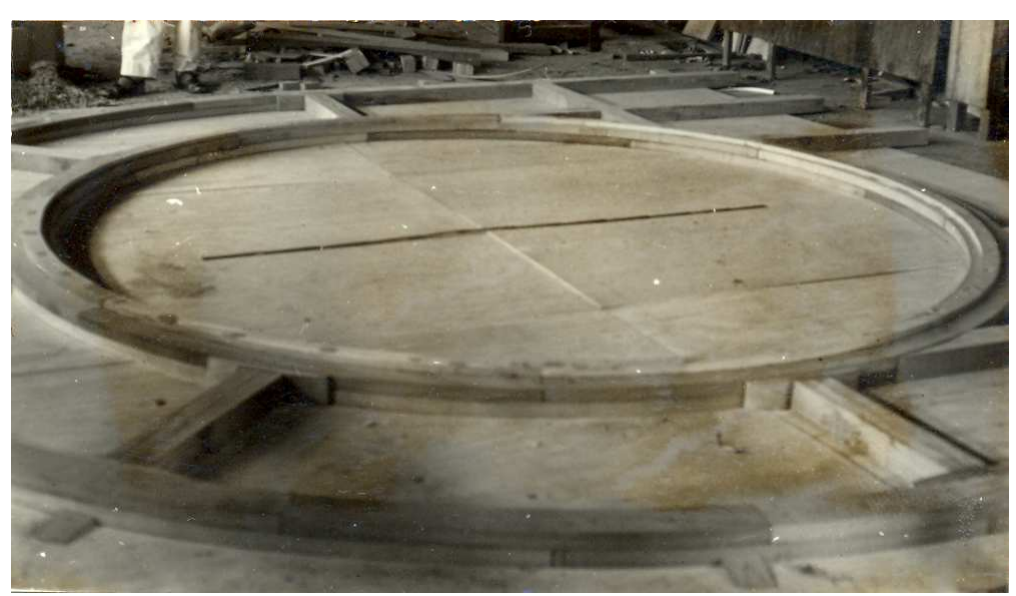

Figura 4.11: Montagem do diafragma e sua armação estrutural

os valores obtidos com os dois métodos coincidiram, no restante do ensaio a vazão foi medida apenas com o diafragma calibrado.

Com esse procedimento foram obtidas as curvas de variação do coeficiente de vazão $C_{q}$ em função do número de Reynolds para os dois diafragmas (o diafragma modelo e o diafragma calibrado). Assim, o coeficiente de vazão do diafragma modelo foi determinado, com o valor, para um número de Reynolds acima do valor crítico, de $C_{q}=0,65$. 


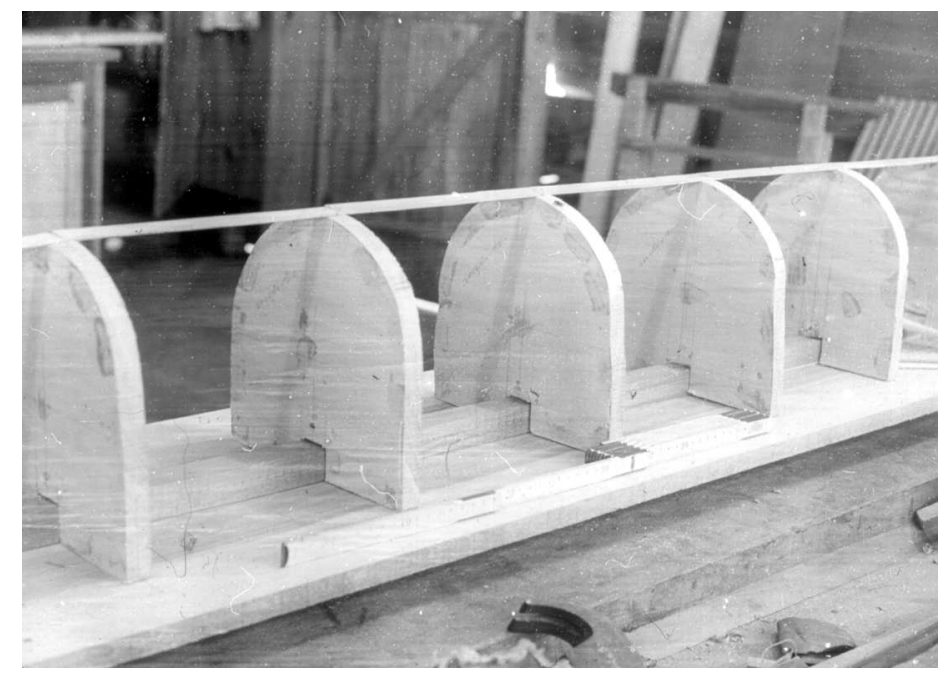

Figura 4.12: Molde para modelagem do modelo do Túnel 2

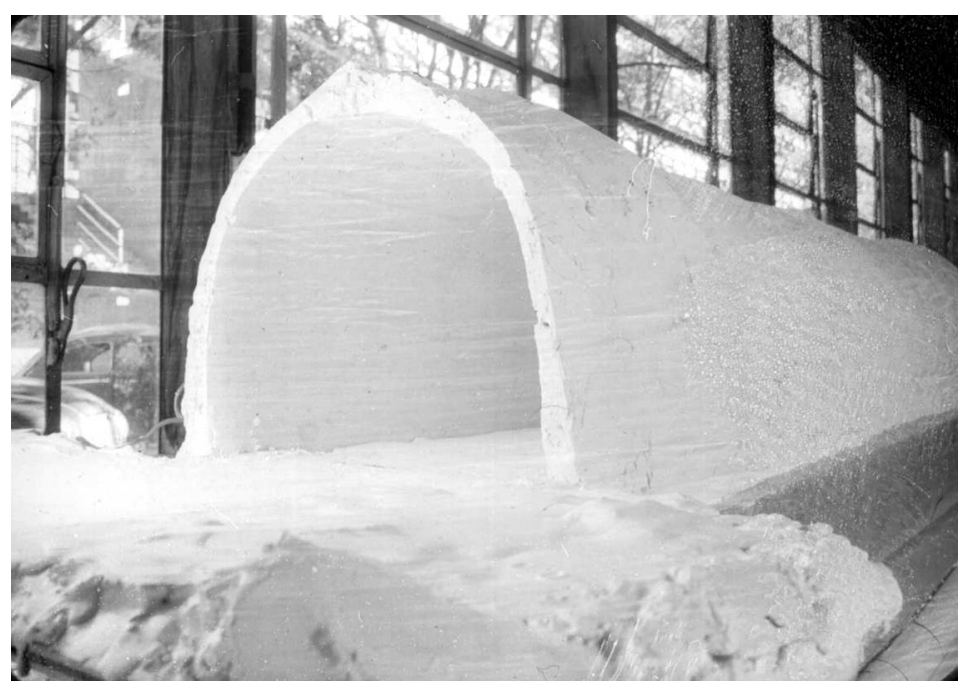

Figura 4.13: Modelo reduzido do Túnel 2 em gesso

\section{Segundo Ensaio}

Assim como no Ensaio Preliminar, no segundo ensaio, um diafragma padrão com orifício circular concêntrico foi utilizado para a medida da vazão, porém, instalado no desemboque ${ }^{8}$ na progressiva 77 , projetado com o objetivo de obter uma perda

\footnotetext{
${ }^{8} \mathrm{Na}$ ocasião do segundo ensaio, o túnel já estava com o revestimento do desemboque finalizado; com o uso do método óptico esta seção se mostrou a melhor alternativa para a instalação do diafragma e levou-se em consideração as vantagens de fácil acesso, facilidade de drenagem, rapidez de instalação e por ser um trecho com perfil de velocidade estável e plenamente estabelecido.
} 


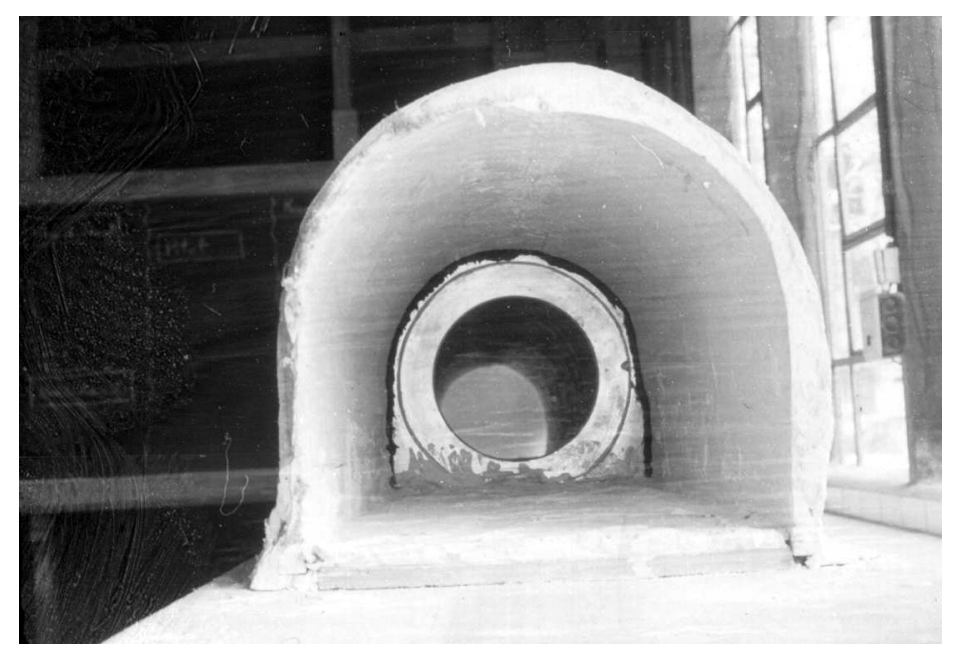

Figura 4.14: Modelo reduzido do trecho inicial de montante do Túnel 2 com o diafragma

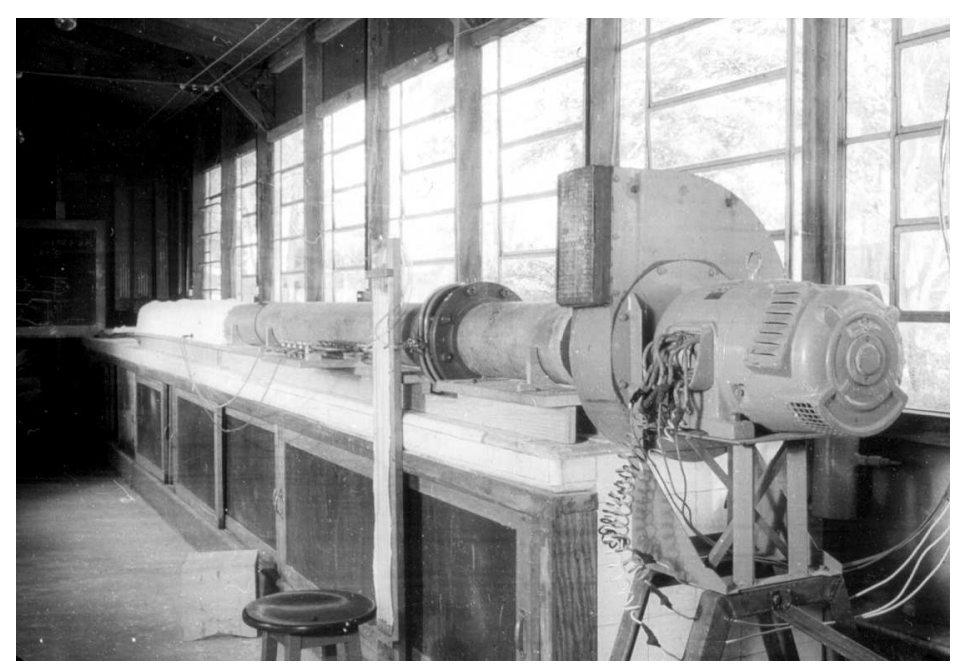

Figura 4.15: Bancada de ensaios do modelo reduzido

de carga mínima e uma diferença de pressões suficientemente grande para poder ser medida com o emprego de manômetro do tipo Betz. Para o diafragma utilizado no Segundo Ensaio foi também ensaiado o seu modelo reduzido.

Para esse ensaio, o trecho final do desemboque do Túnel 2 (local mais apropriado segundo a avaliação feita com o método óptico), com 95 m de extensão, foi reproduzido na escala 1:19. A reprodução em escala da seção do trecho de interesse do túnel, foi obtida através da instalação no fundo de um tubo de cimento 
amianto de classe 15 e diâmetro de $200 \mathrm{~mm}$, de uma chapa metálica, dessa forma obteve-se um "fundo falso", e com isso, a reprodução do formato da seção de interesse do Túnel 2 (figura 4.16).

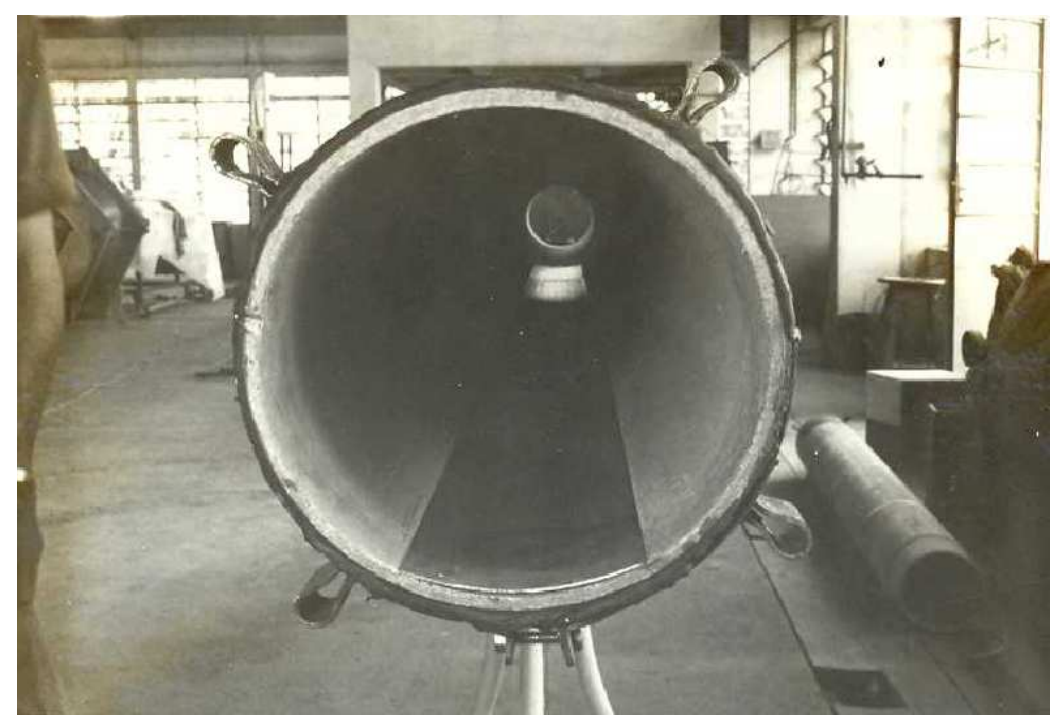

Figura 4.16: Modelo reduzido do Túnel 2 - Segundo Ensaio

O diafragma modelo foi executado em compensado naval com uma das faces aluminizada; as tomadas de pressão foram executadas conforme o sistema empregado no ensaio de campo, ou seja, quatro tomadas de pressão por face, segundo diâmetros perpendiculares (figura 4.20).

O projeto, a execução e a determinação do coeficiente de vazão $\left(C_{q}\right)$ do diafragma usado para o segundo ensaio, foram apresentados em dois anexos ${ }^{9}$ do relatório sobre a perda de carga do Túnel 2. Estes anexos constam de descrição sucinta dos procedimentos de calibração e da execução do diafragma usado no ensaio.

\footnotetext{
${ }^{9}$ Ensaio de Perda de Carga do Túnel 2 - Projeto e Execução do Diafragma Medidor de Vazão (SHS, 1972c) e Determinação do Coeficiente de Vazão $C_{q}$ de um Diafragma Instalado em Seção não Circular (SHS, 1972d).
} 


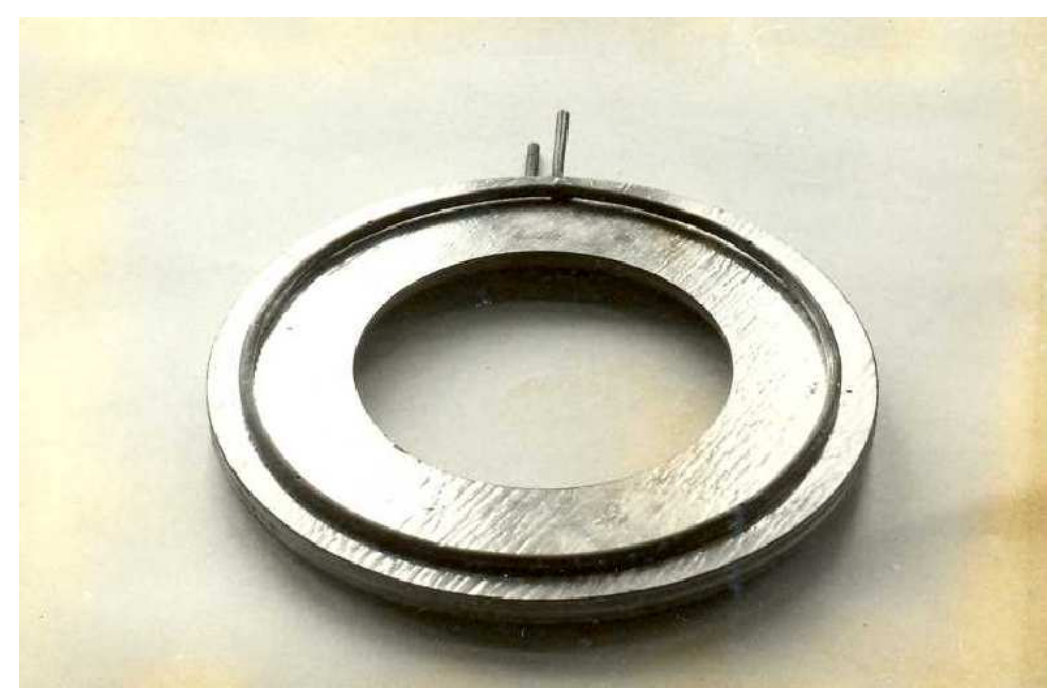

Figura 4.17: Diafragma modelo - Segundo Ensaio

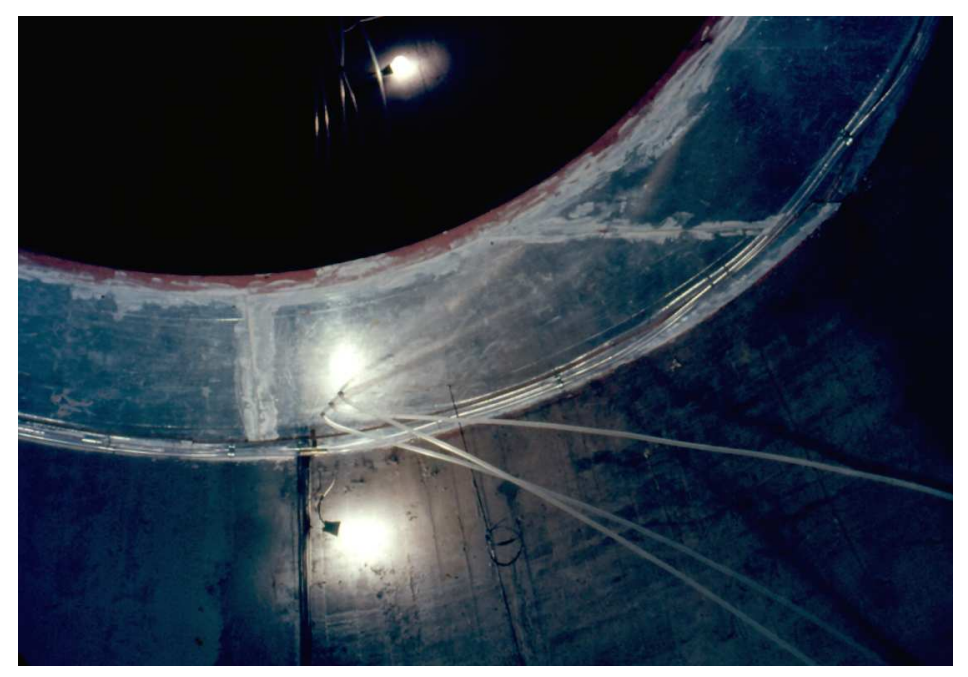

Figura 4.18: Tomada de pressão no diafragma - Segundo Ensaio

\subsection{O Método Óptico}

A escavação de túneis em rocha, mediante desmonte com explosivos, resulta inevitavelmente em um perímetro do túnel que é, em alguns lugares, maiores e em outros menores em relação ao perímetro determinado no projeto (IBARRA e FRANKLIN, 1996). Isto é chamado de, respectivamente, sobrescavação e subescavação (em inglês overbreak e underbreak). A figura 4.21 ilustra um exemplo de sobreescavação e a figura 4.22 uma comparação entre o perfil projetado e 


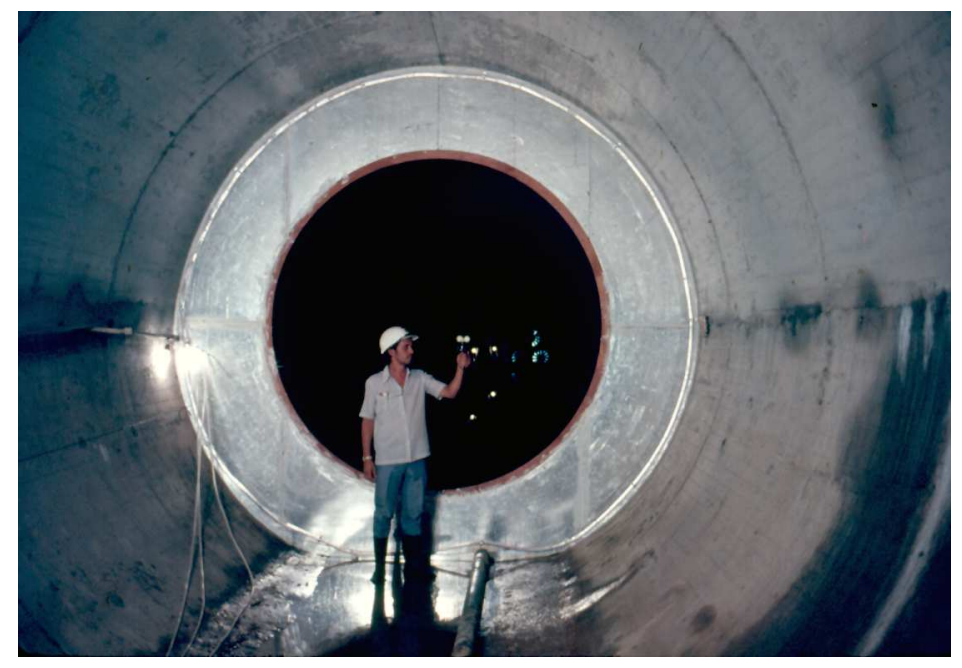

Figura 4.19: Medição da vazão no diafragma com Anemômetro Lambrecht - Segundo Ensaio

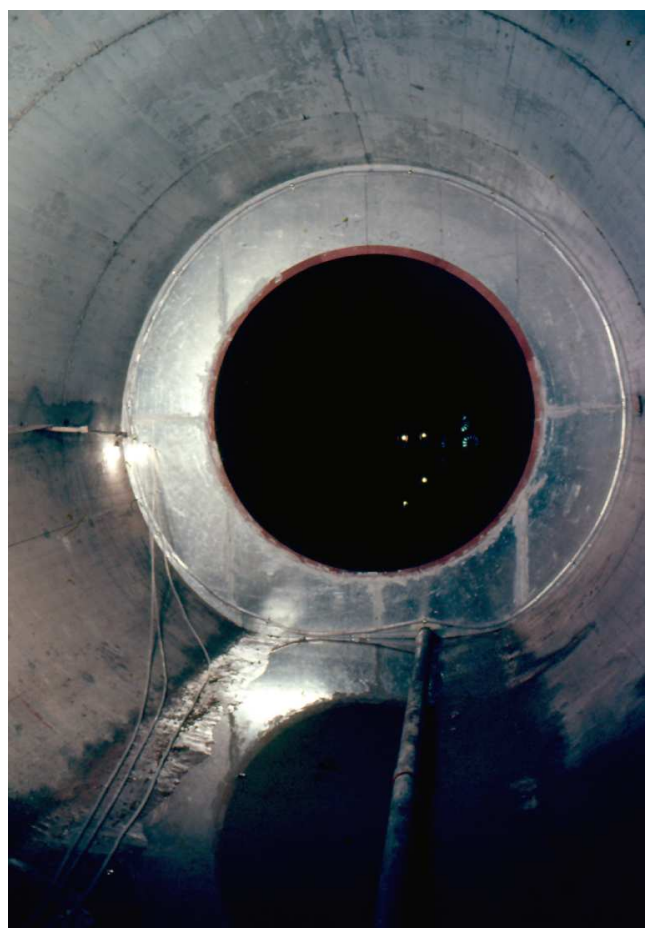

Figura 4.20: Diafragma - Segundo Ensaio 
o executado com explosivos.

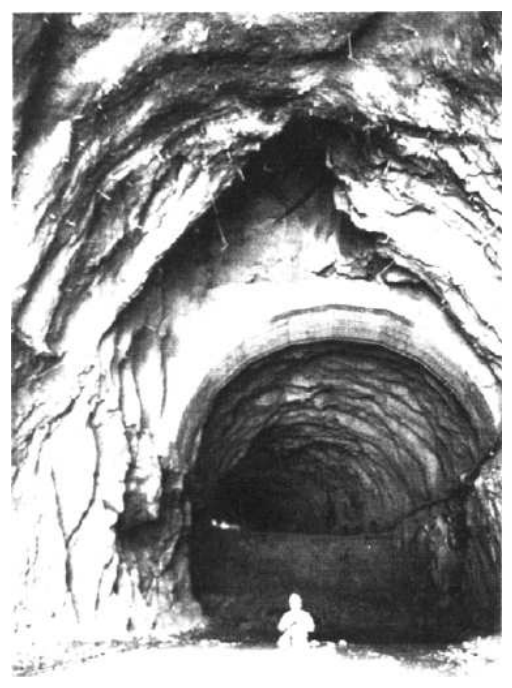

Figura 4.21: Exemplo de sobreescavação

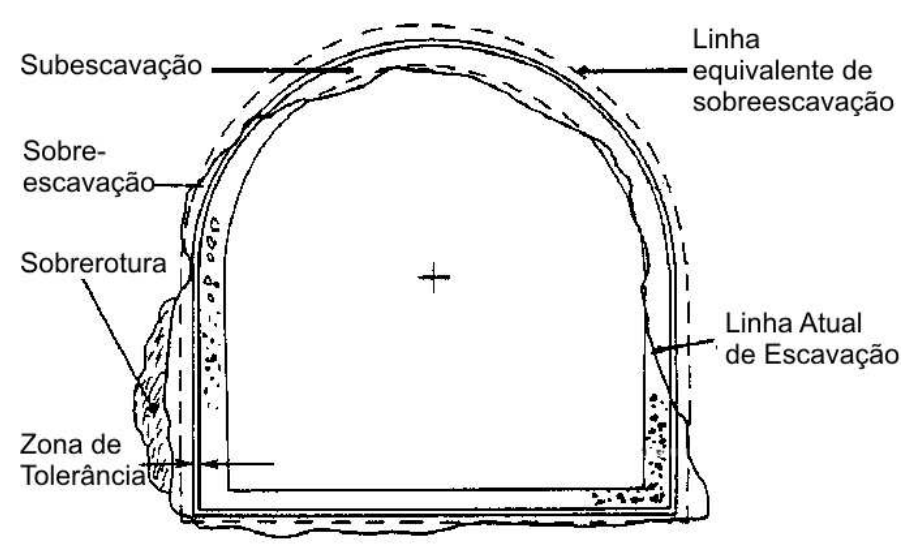

Figura 4.22: Seção do túnel mostrando as linhas de projeto e zonas de sobreescavação e subescavação.

Além do problema da sobreescavação e subescavação produzido pelo método de escavação do Túnel 2, através de explosivos, o projeto da galeria apresenta diferentes tipos de seções ${ }^{10}$, o que agrava ainda mais na determinação dos perfis da galeria.

\footnotetext{
${ }^{10}$ Segundo o Relatório N. 6 da Empresa Redaelli o Túnel 2 possui 14 diferentes tipos de seção em sua extensão (REDAELLI, 1969b).
} 
No caso do Túnel 2, a determinação das seções com a maior precisão possível, se fez necessária devido ao fato da rugosidade relativa, $\epsilon / D_{H}$, e do diâmetro hidráulico $D_{H}$, serem fundamentais para o cálculo da perda de carga $h_{f}$ (equação 2.1), e conseqüentemente na determinação do rebaixamento ideal para que esse pudesse escoar a vazão de $33 \mathrm{~m}^{3} / \mathrm{s}$ de água.

Em túneis hidráulicos o conhecimento do perfil escavado é fundamental no cálculo das perdas e no projeto dos revestimentos. As medidas dos perfis da seção de um túnel podem ser usadas também para a verificação da quantidade de sobreescavação e subescavação, isto é, os desvios da seção transversal de um túnel em relação ao projeto de escavação durante a execução; é importante também para o acompanhamento dos deslocamentos, achatamentos e mudanças na seção do túnel com o passar dos anos.

Frente à necessidade da realização do levantamento das seções do Túnel 2, a equipe responsável pela previsão da perda de carga desenvolveu um equipamento e um método específicos para determinar a área e do perímetro das seções ao longo do Túnel 2, que foi denominado Método Óptico. Esse método consiste da fotografia de uma seção da galeria convenientemente iluminada por um projetor constituído de uma fonte luminosa, colocada entre dois discos concêntricos opacos, afastados entre si por uma pequena distância, que quando colocado no interior do túnel, gerava um plano luminoso e bem determinado nas paredes da galeria. A partir da fotografia desse plano eram determinadas as características geométricas da seção.

O levantamento das seções do Túnel 2 foi solicitado pela COMASP com a 
finalidade de, segundo Arens (2006), ser o as built para as seções da galeria que estava sendo finalizada para uma vazão de projeto $22 \mathrm{~m}^{3} / \mathrm{s}$; este levantamento foi utilizado também para o estudo da disposição dos equipamentos necessários para a execução dos ensaios com circulação de ar e construção dos modelos ${ }^{11}$ reduzidos dos trechos do túnel onde foram instalados os diafragmas.

\subsubsection{Método Óptico Desenvolvido pelo SHS}

O Método Óptico, segundo seu autor, trata-se de um meio cômodo e rápido para a determinação das áreas e dos perímetros de seções irregulares de túneis ou dutos de uma maneira geral (ARENS, 1969). Para Arens (2006), a proposta de fazer o levantamento das seções do túnel através de fotografias, surgiu quando ele, ao ler um jornal de notícias da época, viu uma foto do início das construções dos túneis do metrô de São Paulo, onde as luzes do túnel delineavam sua seção:

“... eu estava lendo um jornal, e vi um túnel que estava sendo construído. Acho que era início do metrô de São Paulo. E aí eu vi na fotografia, na frente do jornal, aros formados pelas lâmpadas utilizadas para o pessoal trabalhar e uma série de circunferências iluminadas, mostrando a profundidade daquele túnel. Eu gostei da fotografia, do seu visual. A luz delineava a seção do túnel. E aí eu aproveitei essa idéia e falei com o professor Ruy Vieira, eu era muito na jovem época. Eu disse: porque ao em vez de medirmos as seções na base da trena ou de outros jeitos, pois já tinham pensado nisso, eu sugeri o seguinte, a gente pode fazer a fotograficamente (Arens 2006, entrevista)".

\footnotetext{
${ }^{11}$ Foram construídos dois modelos reduzidos dos trechos onde se inseriram os diafragmas durante os ensaios: no Ensaio Preliminar, com os dados das seções a partir levantamento com método óptico, foi reproduzido em gesso, na escala 1:22, o trecho do emboque do Túnel 2 onde foi inserido o diafragma para a medição da vazão; no segundo ensaio, a partir do levantamento com o método óptico, foi escolhido um trecho no desemboque para a instalação do diafragma, o modelo reduzido do trecho foi executado em tubo de cimento com diâmetro de $200 \mathrm{~mm}$, na escala 1:19.
} 


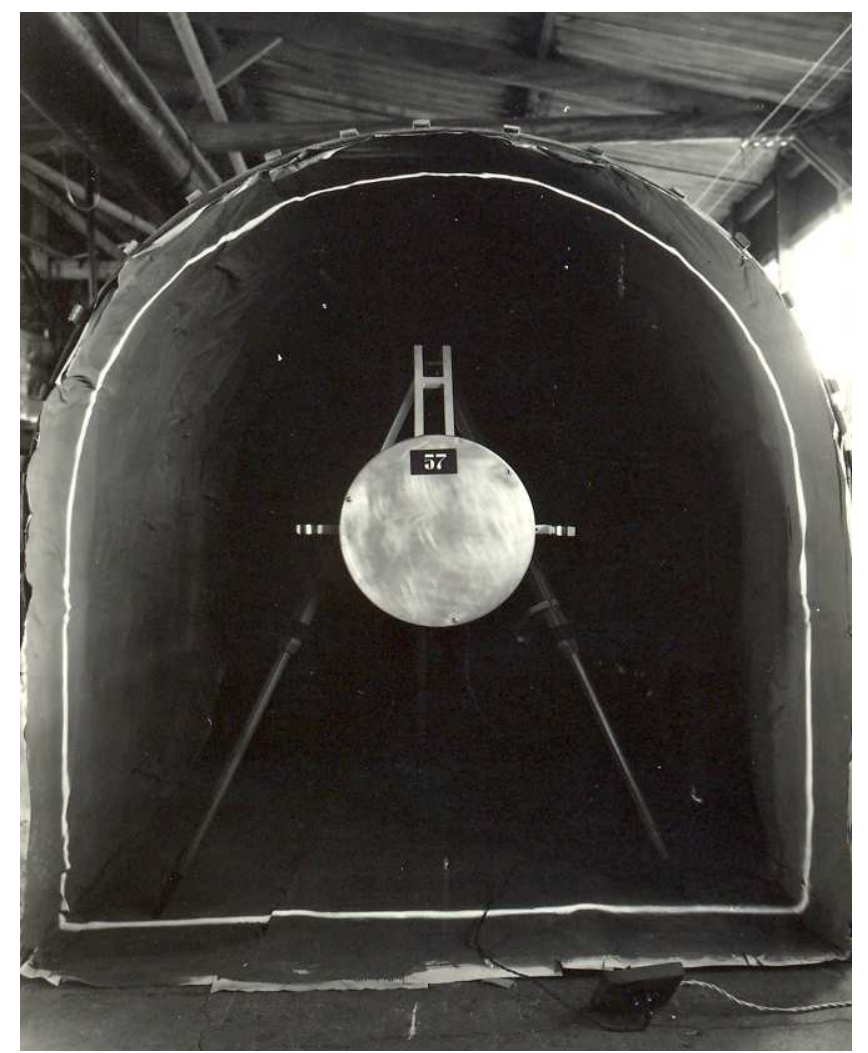

Figura 4.23: Protótipo do Equipamento do Método Óptico

Após ser levantada a hipótese de se fazer o levantamento das seções do Túnel 2 através de fotografias, foi construído e ensaiado um protótipo, figura 4.23, do equipamento para ser utilizado no Método Óptico.

O protótipo do equipamento consistiu de uma fonte luminosa colocada entre dois discos de alumínio com cerca de $400 \mathrm{~mm}$ de diâmetro, afastados entre si de tal forma a produzir uma fresta de cerca de $3 \mathrm{~mm}$, de forma a garantir a geração, na parede do túnel, de um plano luminoso bem determinado, fornecendo o lugar dos pontos nos quais o plano corta o túnel. Esse lugar se distingüe por uma estreita faixa iluminada.

Inicialmente, a fonte luminosa era composta por 10 lâmpadas de $40 \mathrm{~W} 12 \mathrm{~V}$ (figura 4.24) ligadas em série e um ventilador adequado para evitar o aquecimento 


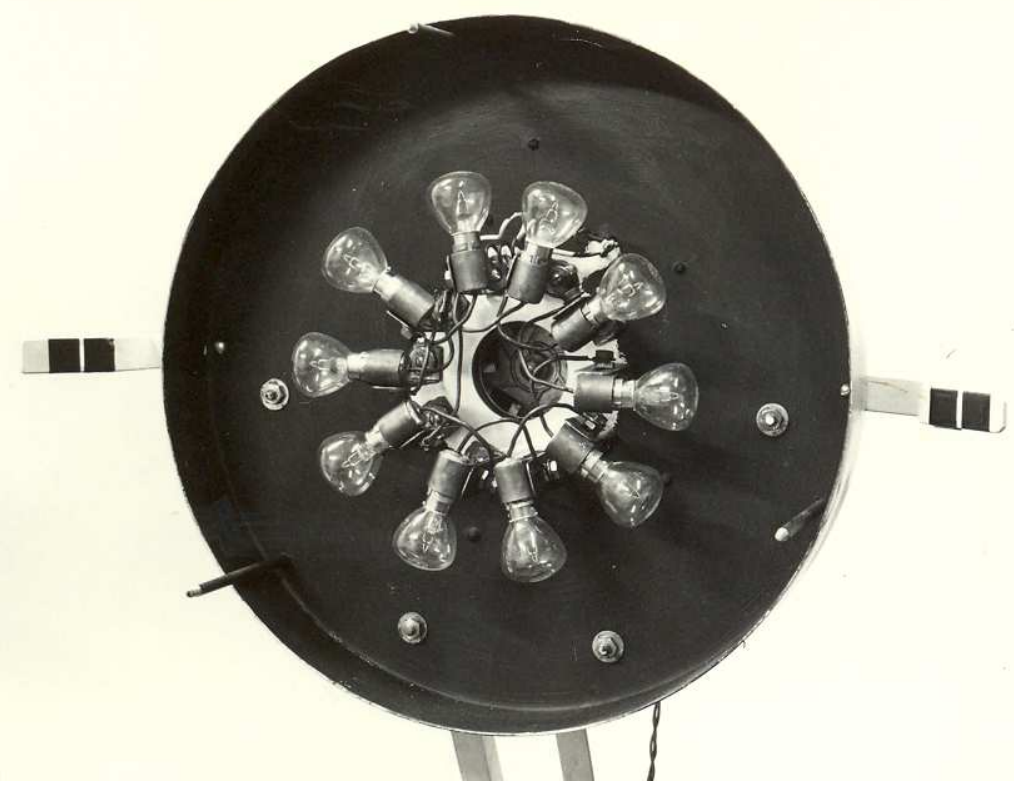

Figura 4.24: Projetor luminoso com lâmpadas

do projetor (figura 4.25).

Mesmo com o uso do ventilador, havia um super aquecimento do equipamento, devido ao tempo de exposição do feixe, e, somando o fato de que as lâmpadas não forneciam a luminosidade suficiente, estas foram substituídas por um flash toroidal ${ }^{12}$ (figura 4.26).

Para efeito de escala, braços com $1 m$ de distância (ponta a ponta), foram ajustados ao equipamento para fornecerem a escala. Na figura (4.27-a), tem-se o equipamento que se utilizava do flash toroidal, e na figura (4.27-b) o equipamento protótipo, que se utilizava de lâmpadas.

O equipamento quando posicionado de forma a haver paralelismo entre o eixo do túnel e o eixo dos discos, faz a faixa luminosa projetada nas paredes da

\footnotetext{
${ }^{12}$ Segundo Arens (entrevista), a sugestão para se utilizar o flash partiu de um funcionário do SHS, o fotógrafo Paulo Pires, que acompanhou todo o desenvolvimento do equipamento, desde seu protótipo ao equipamento final.
} 


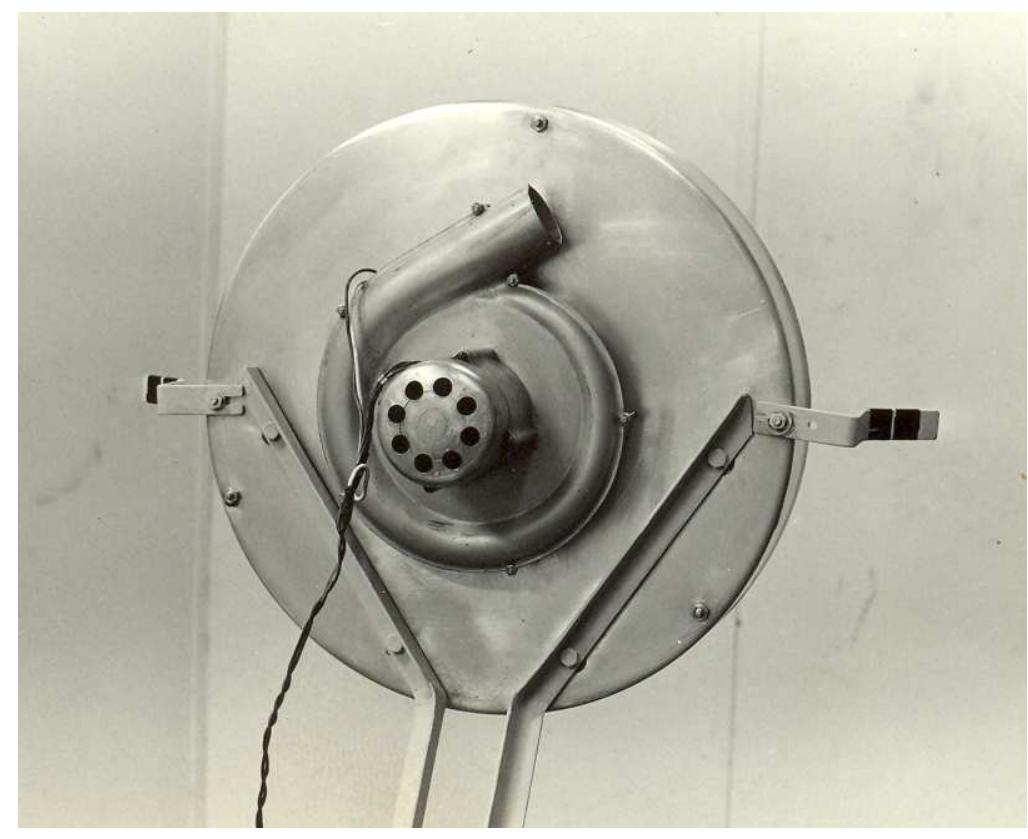

Figura 4.25: Sistema de ventilação do projetor

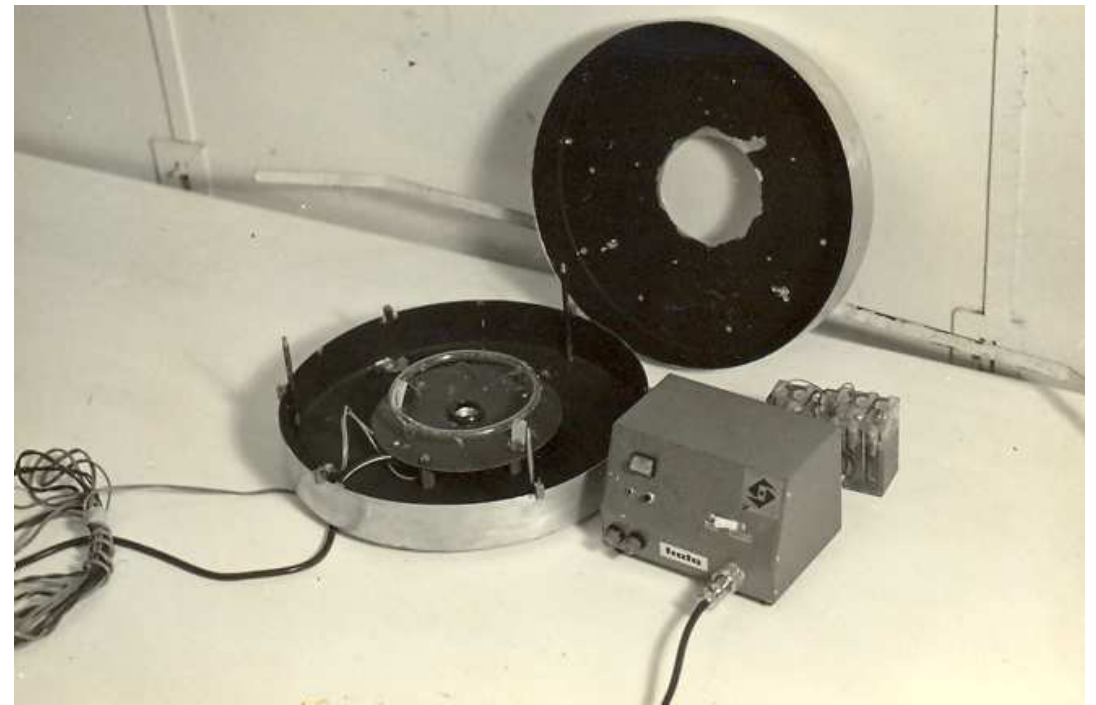

Figura 4.26: Flash Toroidal utilizado no Método Óptico 


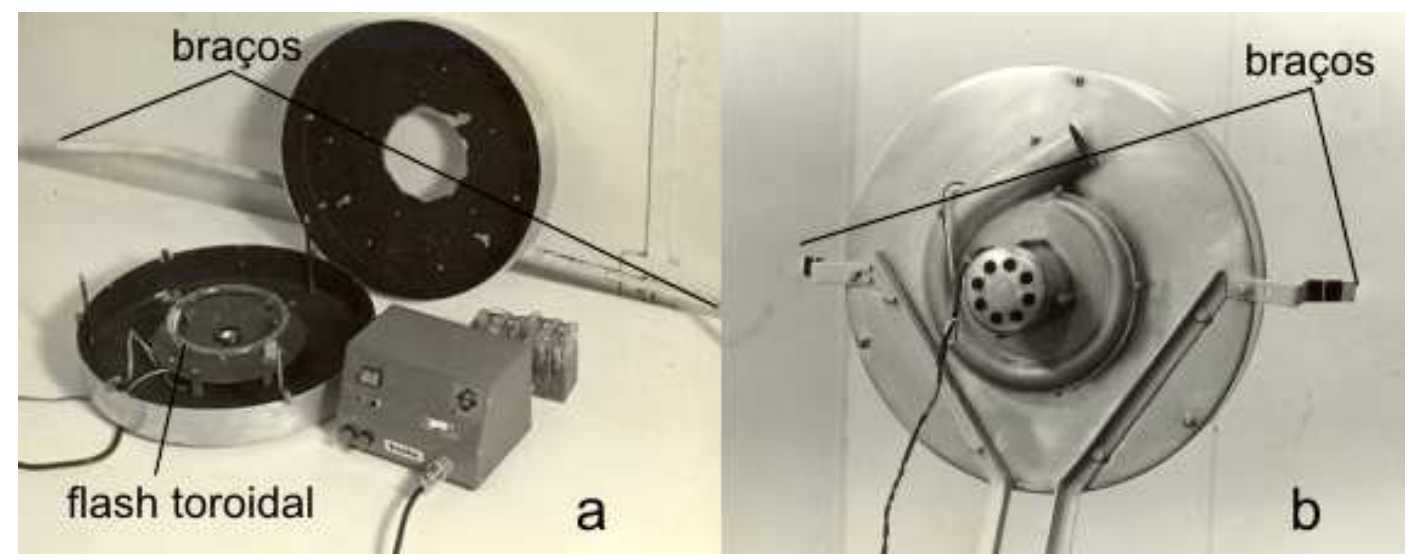

Figura 4.27: Equipamentos do Método Óptico - (a) equipamento usado para levantamento dos perfis do Túnel 2 e (b) protótipo do equipamento

galeria reproduzir fielmente a seção normal do túnel (figura 4.28).

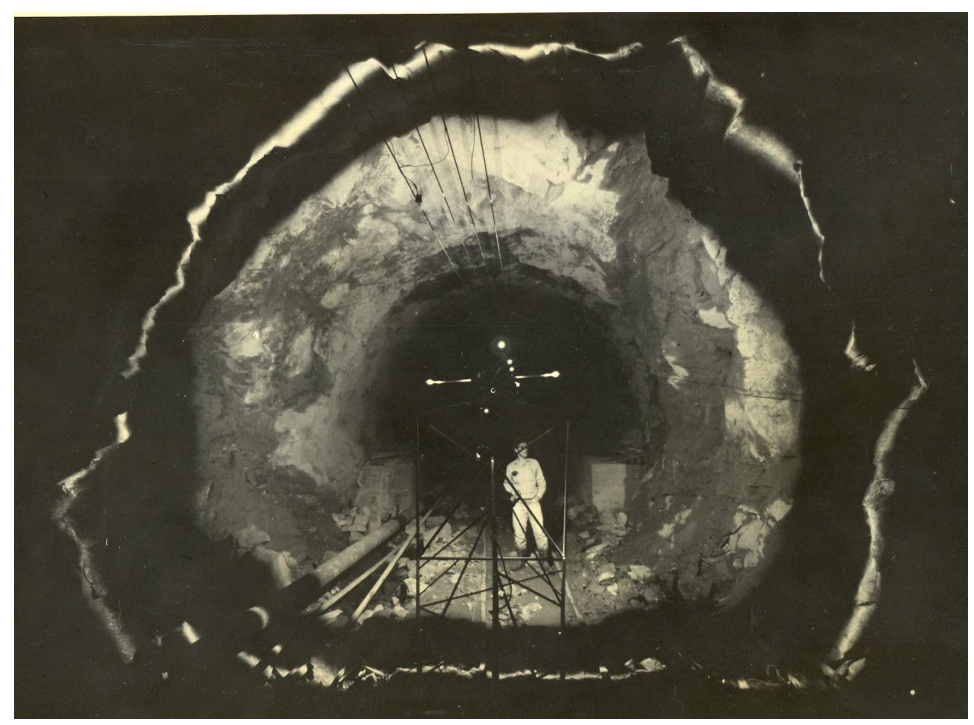

Figura 4.28: Exemplo de um perfil do Túnel 2 obtido com o Método Óptico

O equipamento utilizado para as fotografias constou de uma câmara "Linhof" $9 \times 12$, equipada com uma objetiva Schneider-Kreuznach Angulon 1:6,8-90 $m m$.

Para verificar as possibilidades do método, antes que ele fosse empregando no levantamento das seções do Túnel 2, foi realizado um ensaio em um modelo reduzido de um túnel com 1,5 $\mathrm{m}$ de largura e 1,5 $\mathrm{m}$ de altura, construído de maneira 
a simular as irregularidades de superfície, características de túneis escavados em rocha sem revestimento de concreto, como no caso do Túnel 2.

A área da seção ensaiada foi obtida com um planímetro Amsler e o perímetro com um dispositivo semelhante (ARENS, 1969). Para comparação, a mesma seção foi levantada com o emprego de um teodolito, para tanto, foram marcados 66 pontos sobre a faixa iluminada, de forma a obter uma poligonal fechada. Com a determinação das deflexões horizontais e verticais de cada ponto e a distância entre o centro óptico do instrumento e o plano da seção estudada, foi calculada analiticamente a área e o perímetro da poligonal (a comparação entre os parâmetros obtidos com os dois métodos é apresentada na tabela 4.2.1).

Tabela 4.2: Comparação entre as medidas realizadas com o Método Óptico e com o Teodolito

\begin{tabular}{lcc}
\hline & Método Óptico & Teodolito \\
\hline Área $\left(m^{2}\right)$ & 1,90 & 1,878 \\
Perímetro $(m)$ & 5,67 & 5,472 \\
\hline
\end{tabular}

Uma análise realizada entre os parâmetros determinados com os dois métodos, o óptico e o teodolito, apresentou uma diferença de apenas 3,8\% no perímetro e de 1,6\% na área em relação aos dados obtidos com o teodolito, que são considerados os mais próximos dos valores reais.

Para o uso do método no Túnel 2, foi construído um cavalete que sustentava o projetor em uma extremidade e na outra um apoio para a câmera (figura 4.29). O uso do cavalete apresentava duas vantagens: a primeira em relação à distância entre a câmera e o projetor era sempre constante, e a segunda era que ele era facilmente adaptado aos trilhos já existentes na galeria para a remoção do entulho, isto facilitou tanto o transporte do equipamento quanto a redução no 
tempo gasto na montagem do equipamento.

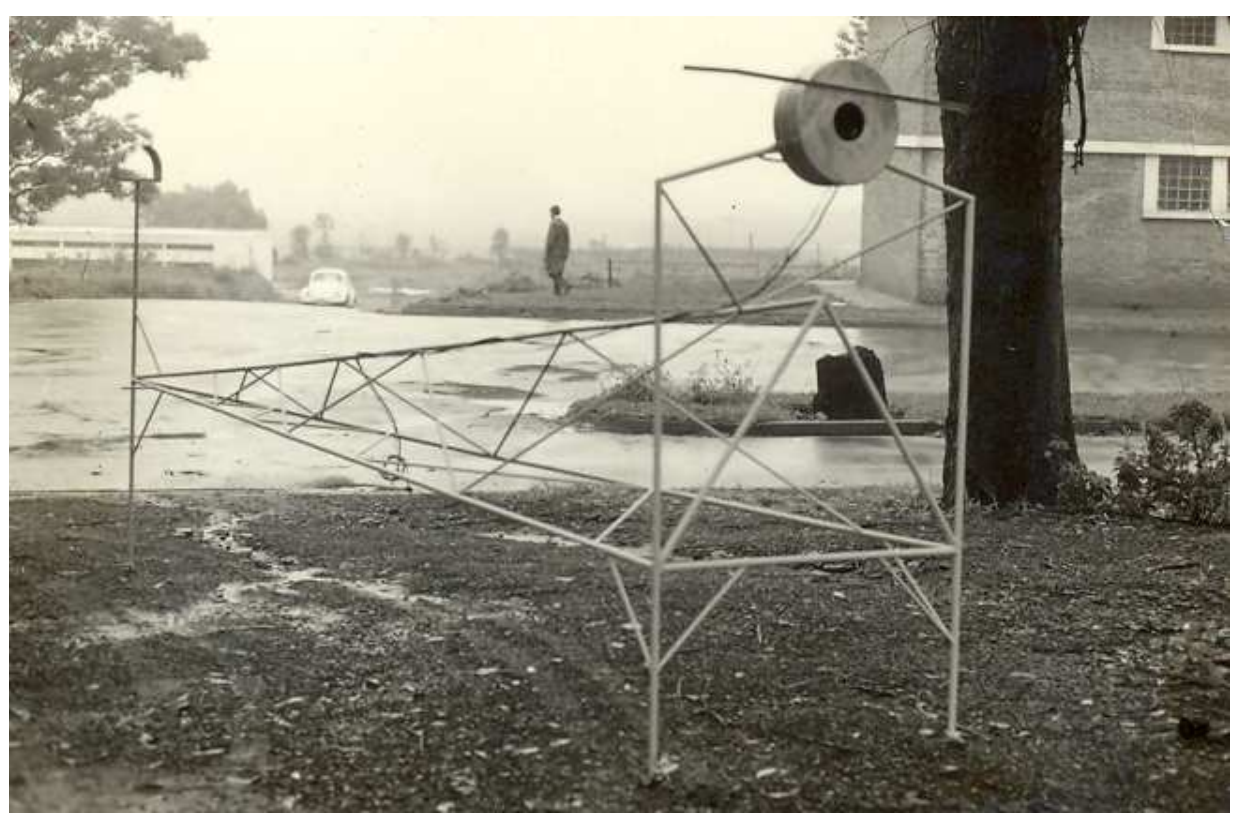

Figura 4.29: Cavalete usado para acomodar os equipamentos utilizados no Método Óptico

O relatório RP-GEDE-14 - Perdas de Carga no Túnel 2 (SWECOCONSULT, 1968), apresenta uma planimetria das seçõoes do Túnel 2 realizada antes do desenvolvimento do método óptico. Essa planimetria foi levantada utilizando o "métodos dos ângulos fixos", relatado no artigo Tunnel Profiling By Photography, (FELLOWS, 1976).

Este método consiste em incorporar uma medida conhecida a uma posição também conhecida da parede do túnel (figura 4.30), obtida através de um alvo apoiado a um tripé colocado na linha central do túnel, em um nível conhecido. A partir de um molde colocado no alvo, indicando ângulos de $30^{\circ}$ e $60^{\circ}$ na horizontal, uma fita é unida a extremidade da haste do molde e fixada deste até a parede do túnel, de forma que a fita, quando tensionada, coincide com um ângulo do molde. Mede-se o comprimento da fita tensionada em cada ângulo do molde, e a partir dessas medidas obtêm-se o perfil medido (figura 4.31). 


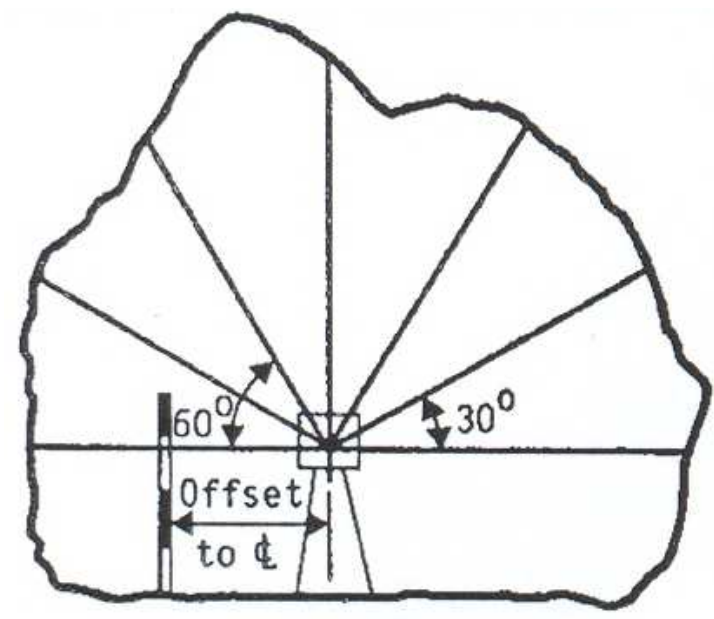

Figura 4.30: Perfil Escavado

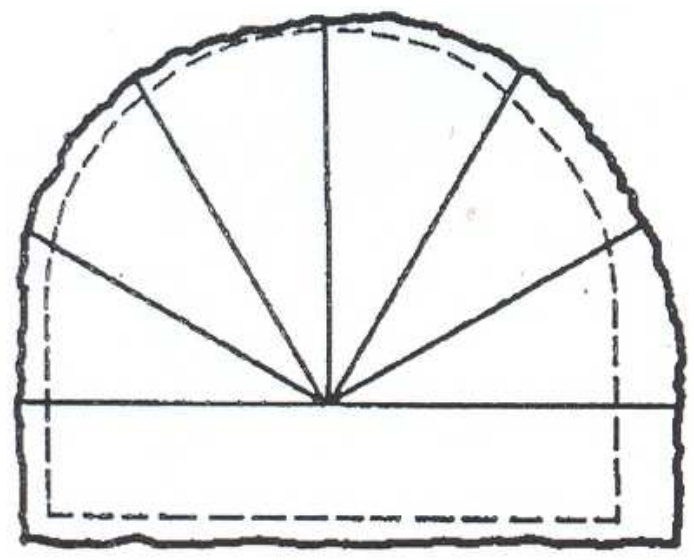

Figura 4.31: Perfil Medido

A figura 4.31 ilustra na linha tracejada o perfil projetado, e a linha contínua o perfil obtido através deste método. Sobrepondo a figura 4.30 na figura 4.31, obtemos a figura 4.32, onde a linha tracejada é o perfil medido e a linha contínua o perfil escavado, mostrando as imprecisões do método.

Segundo Fellows (1976), imprecisões podem ocorrer se a fita não for corretamente tensionada. Para esse método, utilizando a tecnologia disponível na época, eram necessárias três pessoas e os seguintes tempos eram gastos por perfil medido: 


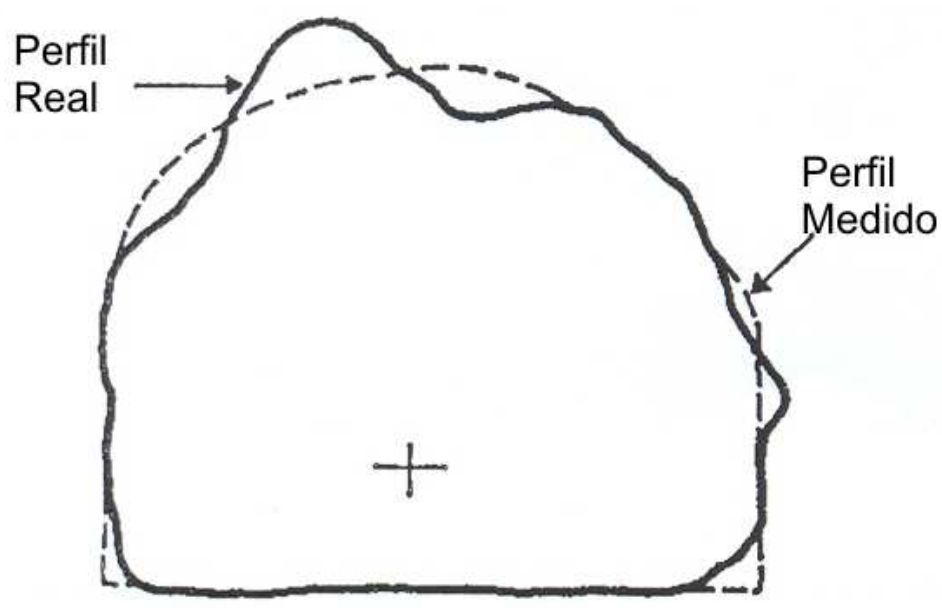

Figura 4.32: Imprecisões obtidas usando o método dos ângulos fixos

Tabela 4.3: Tempo gasto com o método dos ângulos fixos

\begin{tabular}{ll}
\hline Tempo necessário para realizar as medidas & 08 minutos \\
Tempo necessário para desenhar os perfis & 10 minutos \\
Tempo total & 18 minutos/perfil \\
\hline
\end{tabular}

Fellows (1976) apresenta outros dois métodos utilizados até o ano de 1976 para a obtenção das medidas dos perfis de um túnel.

O segundo método descrito pelo autor, o método das fitas paralelas, consiste em medir mais pontos em torno da seção do túnel para melhorar a exatidão. A partir dos comprimentos de fitas estendidas do teto ao piso da galeria, com deslocamentos medidos ao longo do sentido oposto, como detalhado no figura 4.33, é traçado o perfil da seção, figura 4.34. Sobrepondo as figuras 4.33 e 4.34, verifica-se que uma maior precisão é obtida quando comparado com o método dos ângulos fixos, como pode ser visto na figura 4.35 . 


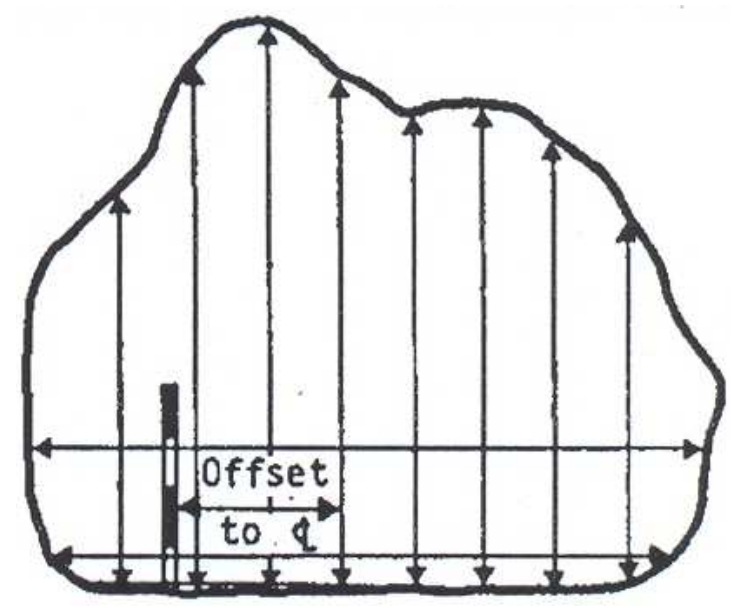

Figura 4.33: Método das fitas paralelas

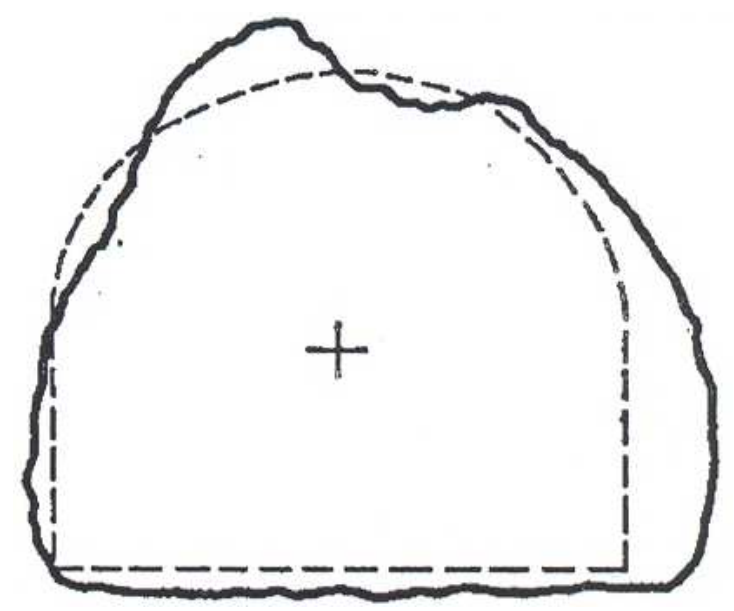

Figura 4.34: Perfil obtido com o método das fitas paralelas e o perfil projetado

Segundo Fellows (1976), o aumento da precisão acarreta em uma demanda maior de tempo em campo, devido à necessidade de ter de elevar uma pessoa para fixar a fita no teto da galeria, e também de tempo extra gasto para desenhar o perfil. Quatro pessoas são necessárias para o levantamento do perfil e são utilizados os seguintes tempos em cada atividade:

Tabela 4.4: Tempo gasto com o método das fitas paralelas Tempo necessário para realizar as medidas 10 minutos Tempo necessário para desenhar os perfis 15 minutos Tempo total 25 minutos/perfil 


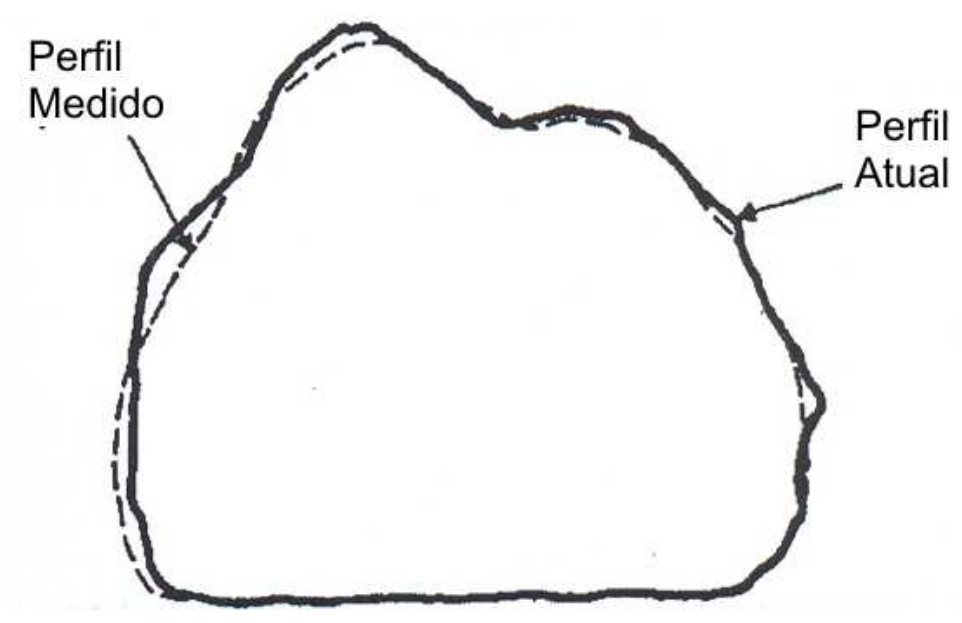

Figura 4.35: Comparação entre o perfil escavado e o obtido com o método das fitas paralelas

O terceiro método relatado por Fellows (1976), conhecido como photoProfiling, é muito semelhante ao "Método Óptico" desenvolvido pela equipe do SHS, tanto na aparelhagem utilizada quanto nos procedimentos para as medidas. Esse método recebeu o nome de 'Waite Plate', em homenagem a pessoa que construiu o primeiro equipamento.

Os autores CLARKE e LINDSEY (1992) relatam que métodos fotográficos para a determinação de perfis de túneis, são utilizados desde o início dos anos 60, mas a primeira publicação sobre o uso do método data de $1972^{13}$, dois anos após o SHS ter desenvolvido o Método Óptico; isso garante a originalidade do método utilizado para a determinação dos perfis do Túnel 2.

\footnotetext{
${ }^{13}$ PROCTOR, D. W. and ATKINSON, K. B. (1972) Experimental photogrametricc wriggle survey in the Second Mersey Tunnel. Tunnels and Tunnelling, PP 115-118.
} 


\section{Capítulo 5}

\section{Os Ensaios do Túnel 2}

Foram realizados dois ensaios com circulação de ar para prever a vazão de água no Túnel 2 do Sistema Cantareira. O primeiro realizado em julho de 1969, denominado de Ensaio Preliminar, teve como objetivo de, a partir dos dados das perdas de carga com a circulação de ar, fazer a previsão da vazão de água que passaria pelo túnel nas condições de desnível estabelecidas no projeto entre montante e jusante, no estado em que se encontrassem as obras de rebaixamento sugeridas para o aumento da vazão de 22 para $33 \mathrm{~m}^{3} / \mathrm{s}$. O Segundo Ensaio foi realizado em 1972, no final das obras de adaptação impostas pelo ensaio preliminar, com o objetivo de verificar, definitivamente, a capacidade de adução do Túnel 2.

Os contatos entre a EESC e a COMASP já eram mantidos desde 1968, quando a EESC realizou uma assessoria à COMASP quanto à escolha das bombas da Elevatória Santa Inês e quanto ao aproveitamento hidroelétrico a jusante do reservatório de Águas Claras, no desemboque do Túnel 2. E em janeiro de 1969, o Prof. Tufi Mamed Assy, da Escola Politécnica da USP e assessor do presidente da 
COMASP, frente às necessidades que a empresa tinha de conhecer a real vazão do túnel 2 nas condições que ele se encontrava, sugeriu como consultor do problema o Professor Ruy Carlos de Camargo Vieira ${ }^{1}$ que imediatamente encaminhou ao Diretor Presidente da COMASP, o Dr. Haroldo Jezler, uma carta proposta com o texto de uma minuta de convênio a ser realizado entre a COMASP e a EESC, onde são oferecidos prestação de assistência e assessoramento: estudos, anteprojetos, ensaios, análises e pareceres relativos a problemas diversos no campo de Mecânica dos Fluidos e no das Máquinas Hidráulicas. Tal convênio, de número 107/69, é firmado no dia $1^{\circ}$ de julho do mesmo ano.

Mesmo antes da assinatura do convênio, em março, é apresentado à COMASP o relatório "Estudos Relativos a Medidas do Túnel 2" que incluía uma análise sucinta das alternativas para medida de vazão, anteprojeto de diafragma e dimensionamento de seu modelo reduzido. E no mês de abril é encaminhada para o Diretor de Construção da COMASP, o Sr. Djalma Guimarães, uma cópia do trabalho An Optical Method to Determine the Hydraulic Diameter of Irregular Duct Sections ${ }^{2}$ de autoria dos professores Ruy Vieira e Hans George Arens. Em abril é solicitado pelo diretor da COMASP a realização de medidas, pelo Método Óptico, de algumas seções do Túnel 2 do Sistema Juquerí, com o objetivo de levar o método ao conhecimento do pessoal da COMASP e realizar estudos comparativos com os outros métodos adotados anteriormente.

\footnotetext{
${ }^{1}$ Engenheiro Mecânico-Eletricista pela USP, foi professor no ITA e professor catedrático da EESC-USP, na área de Mecânica dos Fluidos, com inúmeras publicações técnicas e científicas e de vários livros na área da Engenharia. Atualmente é consultor do CONFEA para assuntos educacionais.

${ }^{2}$ Este trabalho foi apresentado ao XII Congresso da Associação Internacional de Pesquisas Hidráulicas - IAHR - realizado no Japão em 1969.
} 
Para as prestações dos serviços propostos no convênio 107/69, a Cátedra de Mecânica dos Fluidos contava com seis engenheiros e quatro técnicos especializados e acesso ao centro de computação equipado com um IBM-1130². Este convênio já previa a realização do Segundo Ensaio.

\subsection{Os Ensaios de Perda de Carga com Circulação}

\section{de Ar}

O objetivo dos ensaios do Túnel 2 consistiu em estabelecer condições de semelhança entre os escoamentos de ar e de água ao longo do túnel, tendo em vista a previsão da vazão de água a ser aduzida pelo túnel.

O fenômeno de escoamento pode, nesse caso, ser expresso por uma função que liga entre si as seguintes grandezas:

$Q$ - vazão do fluido ao longo do túnel;

$\rho$ - massa específica do fluido em escoamento

$\mu$ - viscosidade do fluido em escoamento

$D_{h}$ - diâmetro hidráulico

$l$ - comprimento do túnel

$\delta$ - rugosidade relativa

\footnotetext{
${ }^{3} \mathrm{Na}$ UNICAMP, O IBM-1130 foi o primeiro computador de seu centro de informática, custou cerca de 200 mil dólares e "cujo desempenho equivaleria ao de uma calculadora de hoje", segundo Eustáquio Gomes, professor aposentado da UNICAMP (?).
} 
$\Delta p$ - perda de carga devido ao escoamento ao longo do túnel

Uma análise dimensional do fenômeno de escoamento permite chegar à função adimensional $\phi$ que liga entre si as grandezas anteriores através de um conjunto de quatro coeficientes adimencionais:

$$
\phi\left(f, \operatorname{Rey}, \delta, l / D_{h}\right)=0
$$

com

$$
f=\frac{\Delta p}{\frac{\rho}{2} V^{2} \frac{l}{D_{h}}}
$$

A condição de semelhança entre os dois escoamentos, de ar e de água, deve ser satisfeita pela igualdade dos respectivos coeficientes $f, R e y, \delta$ e $l / D_{h}$ simultaneamente. Assim, indicando com o índice 1 o escoamento de ar e com o índice 2 o escoamento de água, para haver a semelhança é necessário simultaneamente:

$$
\begin{gathered}
C_{f_{1}}=C_{f_{2}} \\
R e y_{1}=R e y_{2} \\
\delta_{1}=\delta_{2} \\
\left(l / D_{h}\right)_{1}=\left(l / D_{h}\right)_{2}
\end{gathered}
$$

Naturalmente, os dois últimos coeficientes, $\left(l / D_{h}\right)_{1}=\left(l / D_{h}\right)_{2}$, são iguais. Como visto na seção 4, não é necessário a igualdade dos números de Reynolds, 
devido ao fato de que o escoamento, tanto para o ar quanto para a água, corresponder a um número de Reynolds acima do valor crítico (equação 4.4).

Assim, da igualdade dos coeficientes de perda (equação 5.2), temos:

$$
\frac{\Delta p_{1}}{\Delta p_{2}}=\frac{\rho_{1}}{\rho_{2}} \frac{V_{1}^{2}}{V_{2}^{2}}
$$

substituindo $\Delta p=\rho g \Delta h$ na equação (5.3):

$$
\frac{\Delta h_{1}}{\Delta h_{2}}=\left(\frac{V_{1}}{V_{2}}\right)^{2}
$$

da equação da continuidade tem-se:

$$
\frac{\Delta h_{1}}{\Delta h_{2}}=\left(\frac{Q_{1}}{Q_{2}}\right)^{2}
$$

Nos ensaios do Túnel 2, utilizando-se ar em escoamento, foram obtidos os pares de valores correspondentes $\Delta h_{1}$ e $Q_{1}$ para diversas condições de vazão. A partir da análise dos resultados foram previstas as relações entre $\Delta h_{2}$ e $Q_{2}$, e portanto, prevista a vazão ${ }^{4}$ de água ao longo do túnel.

\subsubsection{Ensaio Preliminar}

Segundo o Relatório Preliminar Parcial Referente ao Ensaio de Perda de Carga do Túnel 2 (SHS, 1969b), o Ensaio Preliminar foi executado entre os dias 26 e

\footnotetext{
${ }^{4}$ Quando a vazão $Q_{1}$ se iguala a vazão $Q_{2}$ prevista no projeto, a perda de carga $\Delta h_{1}$ será, numericamente igual a perda $\Delta h_{2}$ nas condições do projeto, no entanto, $\Delta h_{1}$ é medido em metros de coluna de ar enquanto que $\Delta h_{2}$ em metros de coluna de água.
} 
29 de julho de 1969.

Durante o mês de junho e até o dia 25 de julho de 1969, foram executados os equipamentos utilizados para as medidas, o projeto da instalação necessária para o ensaio, a calibração da aparelhagem, o ensaio do modelo reduzido do diafragma, o preparo do pessoal e o transporte dos equipamentos até o Túnel 2.

No dia 26, às 7 horas, iniciou-se a montagem do diafragma no batente previamente chumbado na progressiva 45 do trecho de montante do túnel e a instalação dos ventiladores na estrutura de perfis construídas no desemboque. Concomitantemente procedeu-se a instalação das estações de medida, numeradas de zero a três, no sentido de montante para jusante, bem como a instalação dos tubos de Prandtl para a medida das perdas.

A figura (5.1) ilustra a disposição das estações de medida e posicionamento do diafragma e ventiladores adotada para o ensaio.

No dia 28 procedeu-se a verificação da calibração do diafragma, mediante a obtenção da vazão por integração das velocidades medidas ao longo de diâmetros do orifício e sua comparação com o valor obtido através do coeficiente de vazão do modelo reduzido.

As velocidades foram medidas com uma bateria de tubos de Prandtl ligados a um manômetro múltiplo especialmente construído para o ensaio. Foram preenchidas as folhas de cálculo e construídas as curvas, cuja integração foram realizadas mediante planímetro Amsler. Assim, foi verificada a coincidência entre o valor obtido com a bateria de tubos Prandtl e o valor previsto pelo ensaio do 
Figura 5.1: Esquema do Sistema de Medição usado no Ensaio Preliminar

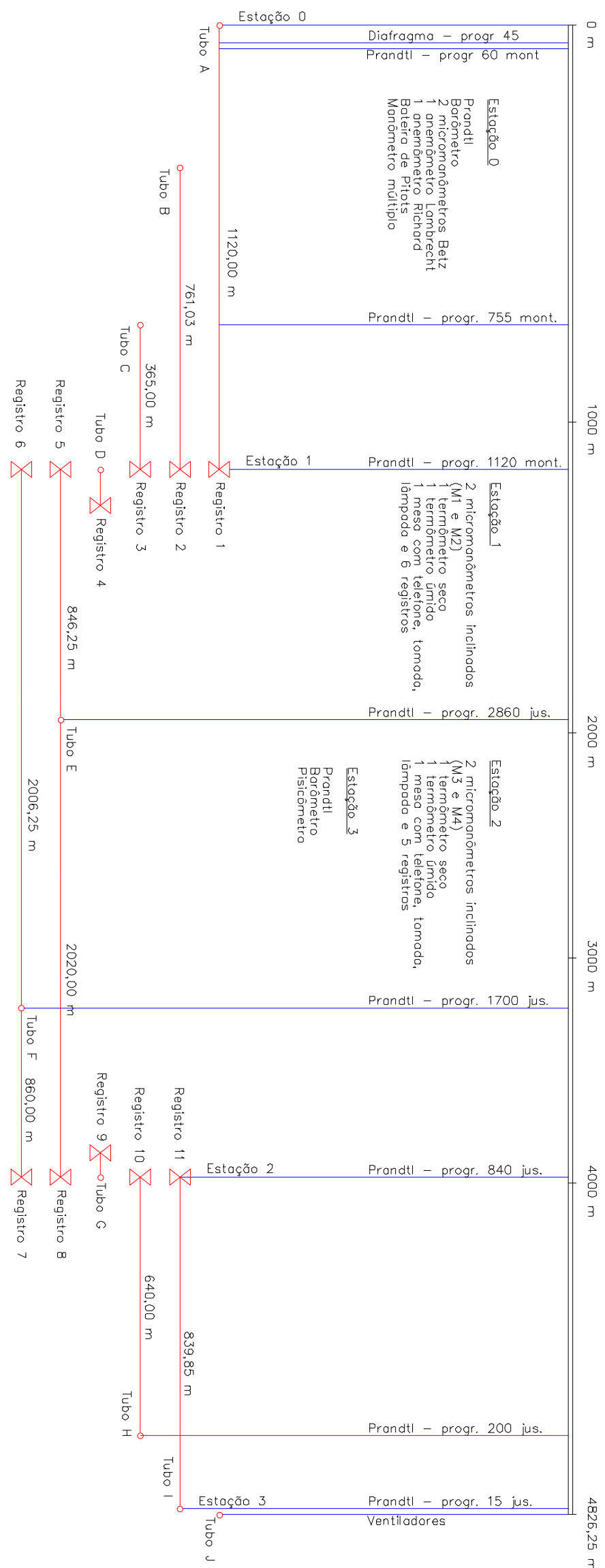


modelo reduzido, dentro de uma precisão de $\pm 3 \%$. Esse resultado mostrou que eram satisfatórias as medidas de vazão por intermédio do diafragma, então foi desmontada a bateria de tubos de Prandtl, obtendo-se todas as vazões através da leitura do diferencial de pressões do diafragama, efetuada utilizando o manômetro óptico tipo Betz, com precisão de 1/20 mm de coluna de água.

As medidas de perda de carga foram efetuadas nos dias 29 e 30, de maneira parcialmente controlada, para permitir a possibilidade de recobrimento dos vários valores obtidos e possibilitar a determinação das características dos vários trechos de interesse.

No final do ensaio, mediante ligação adequada do último tudo de Prandtl, nas imediações do desemboque, foi possível levantar, aproximadamente, as curvas características dos ventiladores, que não forneceram as vazões previstas pelo fabricante.

Mediu-se a diferença de pressões entre a seção interna do túnel nas imediações do desemboque e a pressão atmosférica a jusante, construindo o gráfico da variação dessa diferença de pressões em função da vazão.

Foram consideradas três vazões principais, correspondentes respectivamente às vazões existentes com um, dois e três ventiladores. 
Considerando-se os diversos trechos em que o túnel foi dividido (figura 5.1), as condições para a semelhança entre o escoamento de ar e de água foram aplicados a cada trecho, assim, através das curvas de perda de carga em função da vazão, obtidas no ensaio para cada trecho, obteve-se o valor correspondente da perda de carga no escoamento de água quando a vazão através do túnel fosse de $33 \mathrm{~m}^{3} / \mathrm{s}$.

A tabela (5.1) apresenta as perdas obtidas para os diversos trechos, com seus respectivos comprimentos, para uma vazão de $33 \mathrm{~m}^{3} / \mathrm{s}$. No trecho A-D a perda localizada correspondente à contração brusca ocasionada pelo diafragma foi incluída na perda distribuída.

\begin{tabular}{lcc} 
& \multicolumn{2}{c}{ Tabela 5.1: } \\
\hline & $\begin{array}{c}\text { Perdas } \\
\text { Trecho }\end{array}$ & $\begin{array}{c}\text { Comprimento } \\
(\mathrm{m} \text { col. } \text { ar })\end{array}$ \\
\hline A-D & 4,87 & 1120 \\
D-E & 2,47 & 850 \\
E-F & 7,40 & 1156 \\
F-G & 5,00 & 860 \\
G-I & 0,41 & 849 \\
\hline Fonte: & Relatório Preliminar do Ensaio do Túnel 2, 1969.
\end{tabular}

A partir dos resultados do Ensaio Preliminar, curva representada pela figura (5.2), foi concluído que a perda total, quando a vazão de água no Túnel 2 fosse de $33 \mathrm{~m}^{3} / \mathrm{s}$, seria de 20,15 m de coluna d'água. Como a perda total na realidade deveria ser igual a diferença de nível existente entre as cotas 857,10 $\mathrm{m}$ e $847,40 m$, isto é, igual a 9,70 m, foi concluído que no estado em que se encontrava o Túnel 2 durante o ensaio, não seria possível a adução dos $33 \mathrm{~m}^{3} / \mathrm{s}$ previstos em projeto.

Como existia entulho distribuído ao longo do túnel e água represada em 


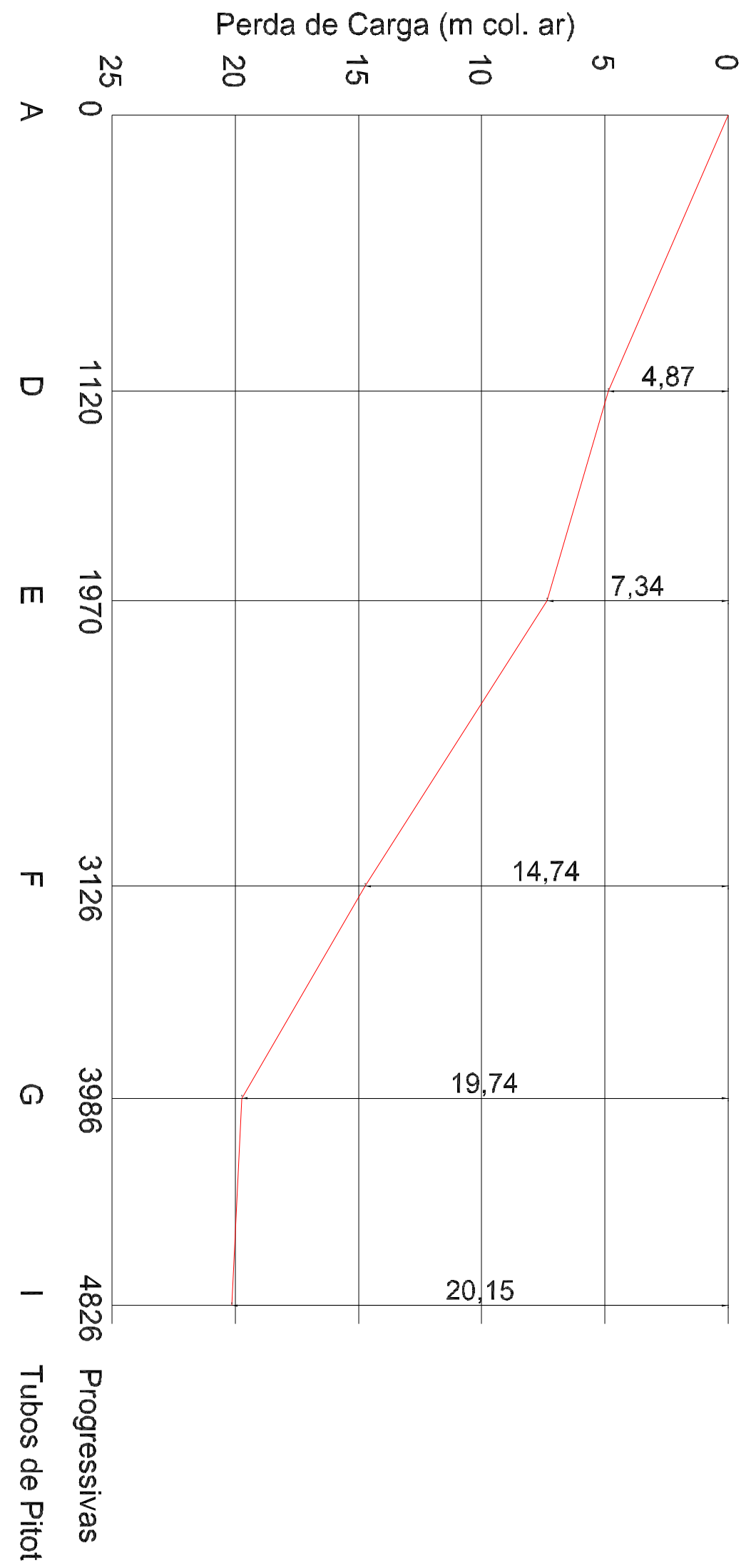

Figura 5.2: Curva da Perda Total no Túnel 2 - Ensaio Preliminar 
extensas bacias resultantes de imperfeições da escavação na bancada, isso alterava as condições do escoamento, devido à redução na área das seções do túnel. Isto posto, tornava necessária uma correção levando em conta essa situação.

Para corrigir o problema foi utilizada a seguinte expressão:

$$
\Delta h^{\prime}=\Delta h\left(\frac{S}{S^{\prime}}\right)^{3}
$$

Em que $\Delta h^{\prime}$ é a perda corrigida, $S$ a área livre da seção transversal característica de cada trecho levando em conta a existência do entulho (área esta obtida com o método óptico), e $S^{\prime}$ a área da seção transversal do trecho respectivo levando em conta a remoção do entulho.

A correção foi realizada, separadamente, para os quatro trechos em que o túnel foi subdividido (A-D, D-E, E-F, F-G E G-I), conforme figura 5.1. Essas correções concluíram que a perda total seria de 14,84 $m$, ainda superior à diferença entre as cotas fixas de montante e jusante, isto é, a 9,70 $\mathrm{m}$. Concluiu-se, portanto, que mesmo com a remoção dos entulhos não seria possível o túnel aduzir os 33 $m^{3} / s$ previstos.

Para a solução do problema, ou seja, para que o túnel pudesse aduzir a vazão prevista, a equipe responsável pelo ensaio sugeriu no relatório "Previsão da Escavação Necessária para a Adução de $33 \mathrm{~m}^{3} / \mathrm{s}$ Através do Túnel 2", o quanto ainda deveria o túnel ter sua bancada rebaixada. Nos cálculos efetuados chegaram à conclusão de que o comprimento que o túnel tinha de ser escavado, rebaixandose a bancada a partir de suas duas extremidades, era de 1732 m, com a hipótese 
de iguais comprimentos a partir de cada extremidade da bancada.

Durante o ensaio, já estavam rebaixados cerca de $2.000 \mathrm{~m}$, restando 2.826 $m$ para serem rebaixados. O ensaio evitou o rebaixamento de $1094 m$, o que representou tanto economia financeira quanto de tempo para as obras do Túnel 2 .

\subsubsection{Segundo Ensaio}

Após a execução do Ensaio Preliminar do Túnel 2, o SHS foi novamente solicitado, em 1972, para a realização do ensaio definitivo, nos mesmos moldes do ensaio anterior.

Houve poucas mudanças entre os dois ensaios. Com um tempo maior entre a contratação do ensaio e a sua realização, foi possível planejar com mais detalhes cada etapa, como por exemplo, o ensaio dos ventiladores usados em campo.

Contando com o túnel já finalizado, neste ensaio optou-se pela instalação do diafragma no trecho revestido de jusante, como pode ser visto na figura (5.3). Outra diferença em relação ao Ensaio Preliminar, foi a dimensão do modelo reduzido do trecho do túnel e do diafragma. No primeiro a escala do modelo foi de $1: 22$ e no segundo $1: 19$. 
Figura 5.3: Esquema do Sistema de Medição usado no Segundo Ensaio

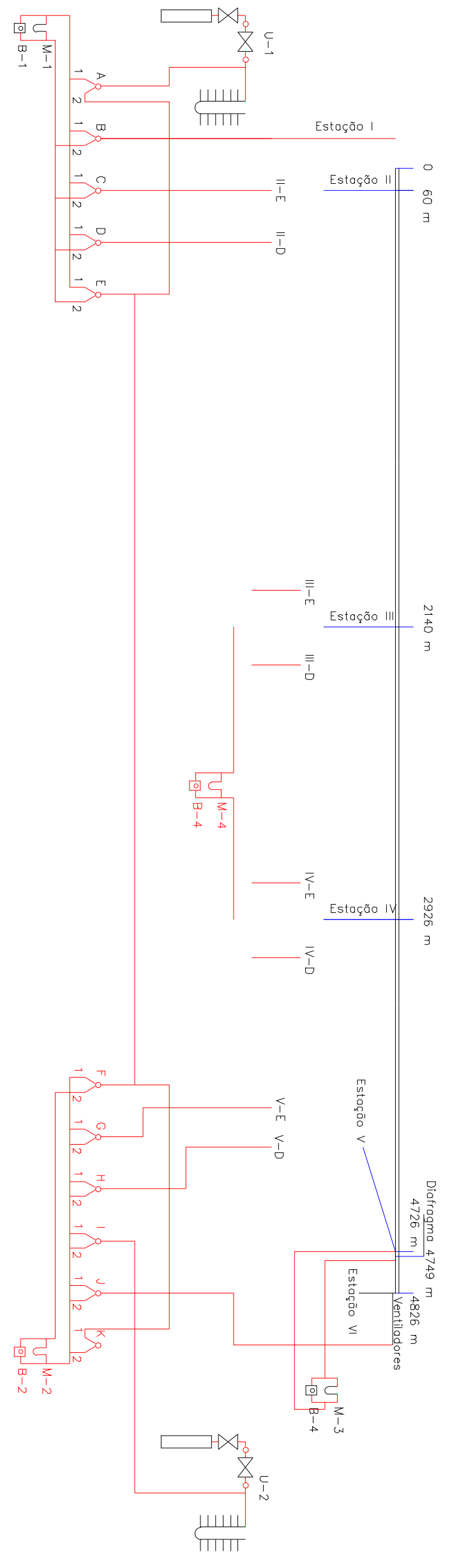


Foram realizadas várias visitas de inspeção ao Túnel 2 antes do ensaio. Nessas visitas foi feito o levantamento fotográfico preliminar, com o método óptico (figuras 5.4), das seções transversais do trecho revestido de jusante, para a determinação da localização do diafragma, dos ventiladores e das estações de medidas, como mostra a figura (5.3).
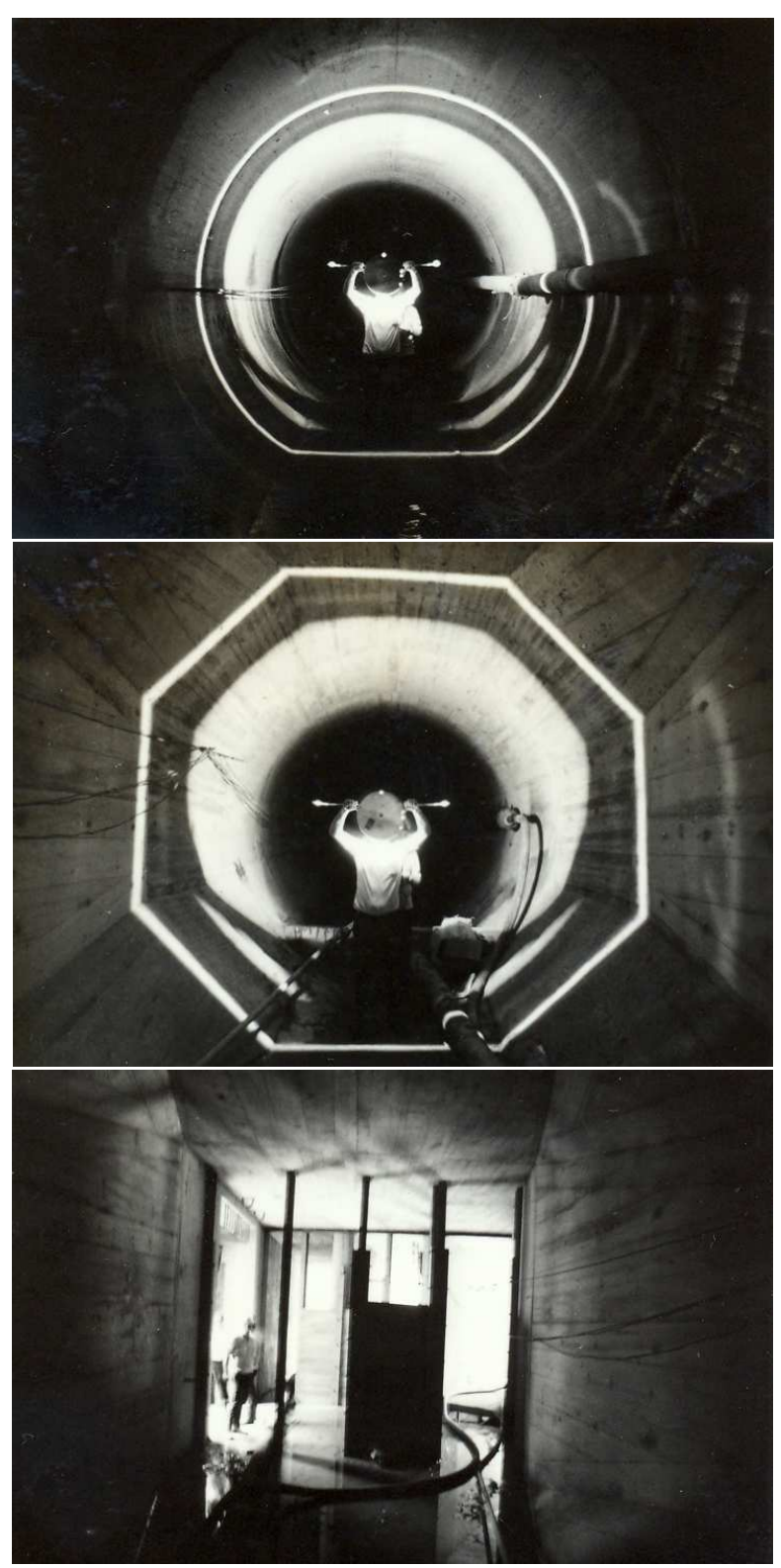

Figura 5.4: Levantamento fotográfico das seções transversais do desemboque do Túnel 2 - Segundo Ensaio

Assim como no Ensaio Preliminar, no período que antecedeu o Segundo 
Ensaio foram realizadas diversas atividades denominadas de atividades de suporte, que consistiram no projeto e construção do diafragama medidor da vazão, ensaio dos ventiladores utilizados, projeto e execução da fixação dos ventiladores in loco e obtenção do coeficiente de vazão do diafragma mediante modelo reduzido.

O projeto do diafragma medidor de vazão levou em conta a ordem de grandeza da perda localizada máxima, tendo em vista simultaneamente as características reais dos ventiladores e a previsão teórica da perda ao longo do túnel. O diafragma localizou-se na progressiva 77 de jusante, em trecho revestido (figura $5.5)$.

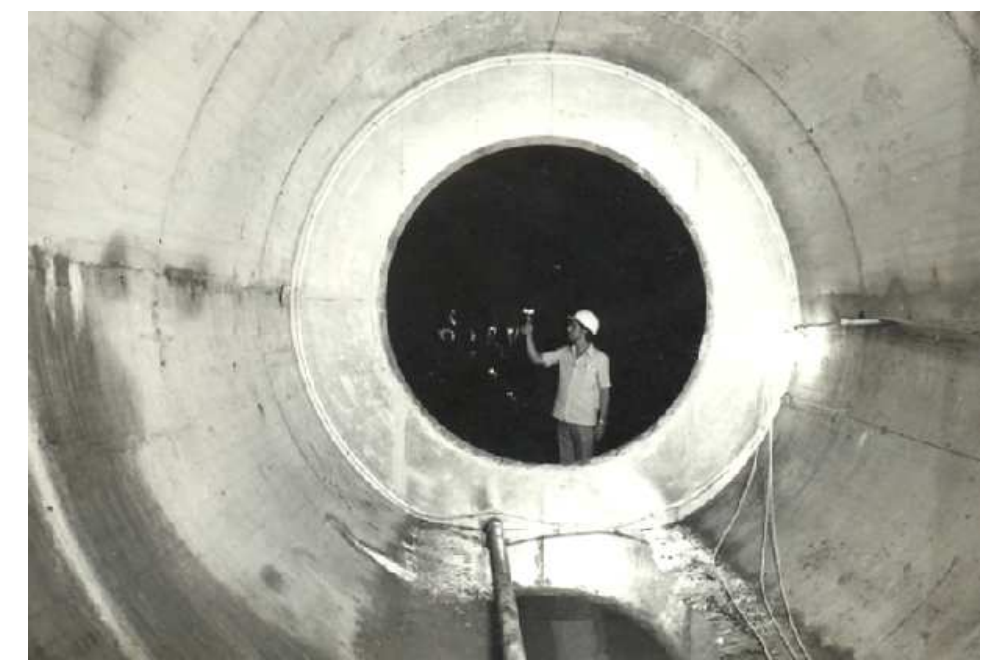

Figura 5.5: Diafragma instalado no desemboque do Túnel 2 - Segundo Ensaio

Entre os dias 21 e 25 de março de 1972, foram transportados da EESC para o local do ensaio, todos os equipamentos e aparelhagem utilizadas no ensaio e os técnicos encarregados da montagem do diafragma. Para tanto, foi utilizado um caminhão (figura 5.6) para o transporte do diafragma e equipamentos menos sensíveis; para os equipamentos mais delicados, foram utilizados automóveis do 
SHS. Nesse mesmo período, foi instalado no túnel um sistema de comunicação cedido pelo exército que consistiu de uma linha tronco instalada ao longo do túnel, com aparelhos no emboque, desemboque e início e fim da bancada.

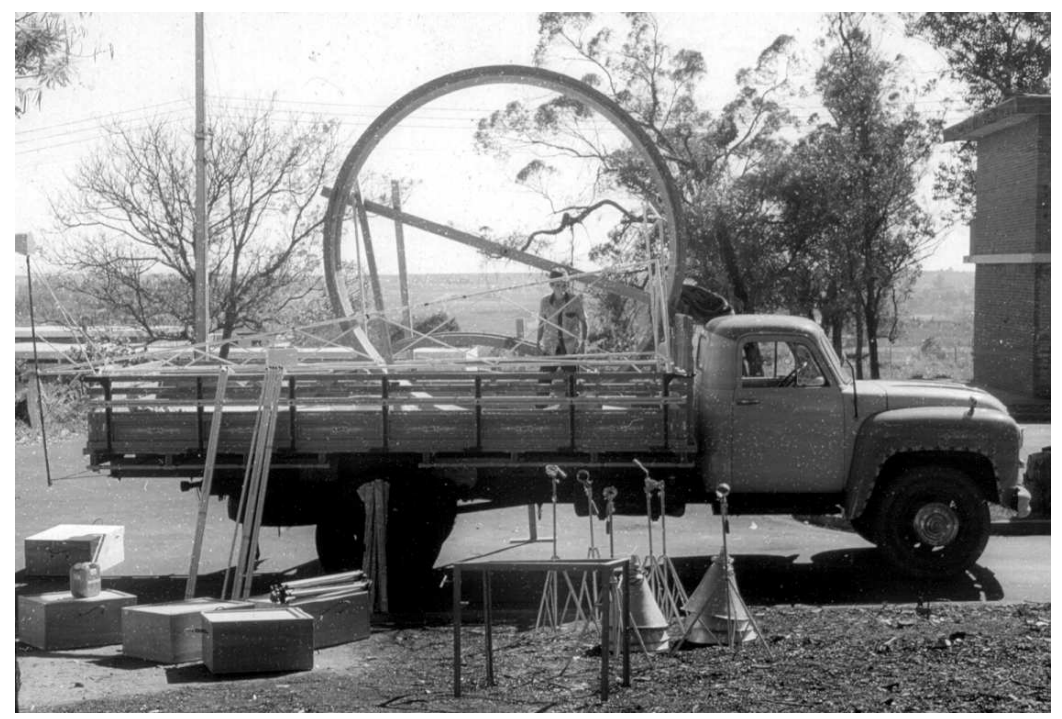

Figura 5.6: Caminhão utilizado para transporte dos equipamentos - Segundo Ensaio

Ainda entre os dias 21 e 25 de março, foi estendida ao longo do túnel uma linha constituída de mangueira plástica de $3 / 16$ " utilizada para a tomada das pressões de diâmetro interno, e nela, instalados os tubos de Pitot.

O ensaio propriamente dito foi realizado entre os dias 25 (a tarde) e 30 de março, como pode ser verificado no cronograma apresentado no relatório Ensaio de Perda de Carga do Túnel 2 "Sistema Cantareira" (SHS, 1972).

Inicialmente foi efetuado o teste de vazamento da linha; a partir do acionamento de um ventilador foram anotados os valores nos dois manômetros em função do tempo. O equilíbrio das leituras foi obtido após 145 minutos.

Com um anemômetro Lambrecht foi medida a distribuição das velocidades no diafragma e comparadas com as obtidas pelo anemômetro Betz. Foram ver- 
ificadas também a distribuição das umidades ao longo do túnel, determinando a progressiva de saturação para diversas vazões, a fim de se poder calcular com segurança a massa específica do ar em escoamento na seção onde estava inserido o diafragma. Conferiu-se a rotação dos ventiladores e as demais características de interssse para o seu funcionamento.

Com os testes e verificações acima citados, foi comprovado o perfeito estado de estanqueidade da linha, conexões, registros e manômetros, assim, deu-se início à fase de aferição e ensaio.

A partir da combinação de $2,2 \frac{1}{2}$ e 3 ventiladores, foram obtidas as vazões utilizadas nos ensaio, estas variaram de $33,11 \mathrm{~m}^{3} / \mathrm{s}$ a $46,53 \mathrm{~m}^{3} / \mathrm{s}$. A tabela (5.2) apresenta as medidas efetuadas durante o ensaio e a vazão corrigida mediante a utilização do coeficiente de vazão obtido com o ensaio do modelo reduzido realizado no laboratório do SHS.

Tabela 5.2: Vazões obtidas com o escoamento de ar

\begin{tabular}{|c|c|c|c|c|c|}
\hline \multicolumn{2}{|c|}{2 Ventiladores } & \multicolumn{2}{|c|}{2 1/2 Ventiladores } & \multicolumn{2}{|c|}{3 Ventiladores } \\
\hline $\begin{array}{c}\Delta h \\
(m . c o l . a r)\end{array}$ & $\begin{array}{c}Q \\
\left(m^{3} / s\right)\end{array}$ & $\begin{array}{c}\Delta h \\
\text { (m.col.ar) }\end{array}$ & $\begin{array}{c}Q \\
\left(m^{3} / s\right)\end{array}$ & $\begin{array}{c}\Delta h \\
\text { (m.col.ar) }\end{array}$ & $\begin{array}{c}Q \\
\left(m^{3} / s\right)\end{array}$ \\
\hline 7,82 & 33,11 & 11,20 & 39,86 & 14,19 & 46,38 \\
\hline 7,51 & 33,11 & 11,20 & 39,86 & 13,96 & 45,78 \\
\hline 7,21 & 33,11 & 11,04 & 39,86 & 14,34 & 46,24 \\
\hline 7,05 & 32,69 & 11,27 & 39,86 & 14,57 & 46,53 \\
\hline 7,05 & 32,87 & 11,04 & 40,21 & 14,72 & 46,53 \\
\hline 7,05 & 32,87 & 10,89 & 39,86 & 15,04 & 46,08 \\
\hline 6,67 & 32,87 & 11,20 & 40,21 & 14,87 & 46,38 \\
\hline 6,83 & 32,87 & 11,35 & 40,04 & 14,65 & 46,24 \\
\hline 6,97 & 32,69 & - & - & 14,65 & 46,24 \\
\hline 6,75 & 32,69 & - & - & - & - \\
\hline
\end{tabular}

Para traçar a curva mas provável das perdas, foi feita uma programação para computador, que por meio do método dos mínimos quadradas, interpolou 
uma parábola através das nuvens de pontos correspondentes ao ensaio nas três situações da tabela (5.2).

A curva das perdas, (figura 5.7), foi obtida com o plotter do computador IBM 1130, do Centro de processamento de dados da EESC. Nessa curva tem-se $\Delta h$ em metros de coluna de ar e nas abcissas, a vazão de ar $Q$ em $\mathrm{m}^{3} / \mathrm{s}$. Esta curva corresponde à curva de perdas do túnel quando se der o escoamento de água, desde que se tome a perda $\Delta h$ em metros de coluna de água.

Com o auxilio do computador, foi obtido também o valor da constante $K$ que relaciona $\Delta h \operatorname{com} Q$ através da expressão

$$
\Delta h=K Q^{2}
$$

Com o valor de $K(K=0,0068130$ para $\Delta h$ medido em metros e $Q$ em $\left.m^{3} / s\right)$ foi calculado o valor previsto para a perda $\Delta h$ quando escoasse através do túnel a vazão de $33 \mathrm{~m}^{3} / \mathrm{s}$. O valor obtido foi $\Delta h=7,42 \mathrm{~m}$.

A perda total quando da vazão de $33 \mathrm{~m}^{3} / \mathrm{s}$ de água, tem de se igualar à diferença de cotas entre montante $(857,10 \mathrm{~m})$ e jusante $(847,40 \mathrm{~m})$, ou seja, $\Delta h_{\max }=9,70 \mathrm{~m}$

Como o valor obtido pelo segundo ensaio foi inferior ao valor máximo, concluiu-se que nas condições em que se encontrava o túnel por ocasião do ensaio de perda de carga, a vazão que o Túnel 2 poderia aduzir era de até $37,7 \mathrm{~m}^{3} / \mathrm{s}$.

No resultado apresentado à COMASP, não foi corrigido o efeito da diminuição 
da seção de alguns trechos do túnel devido ao acúmulo de água, mas devido o fato de a perda medida com a geometria existente ser inferior ao limite máximo de 9,70 m, não foram necessárias maiores preocupações nesse sentido (SHS, 1972). 


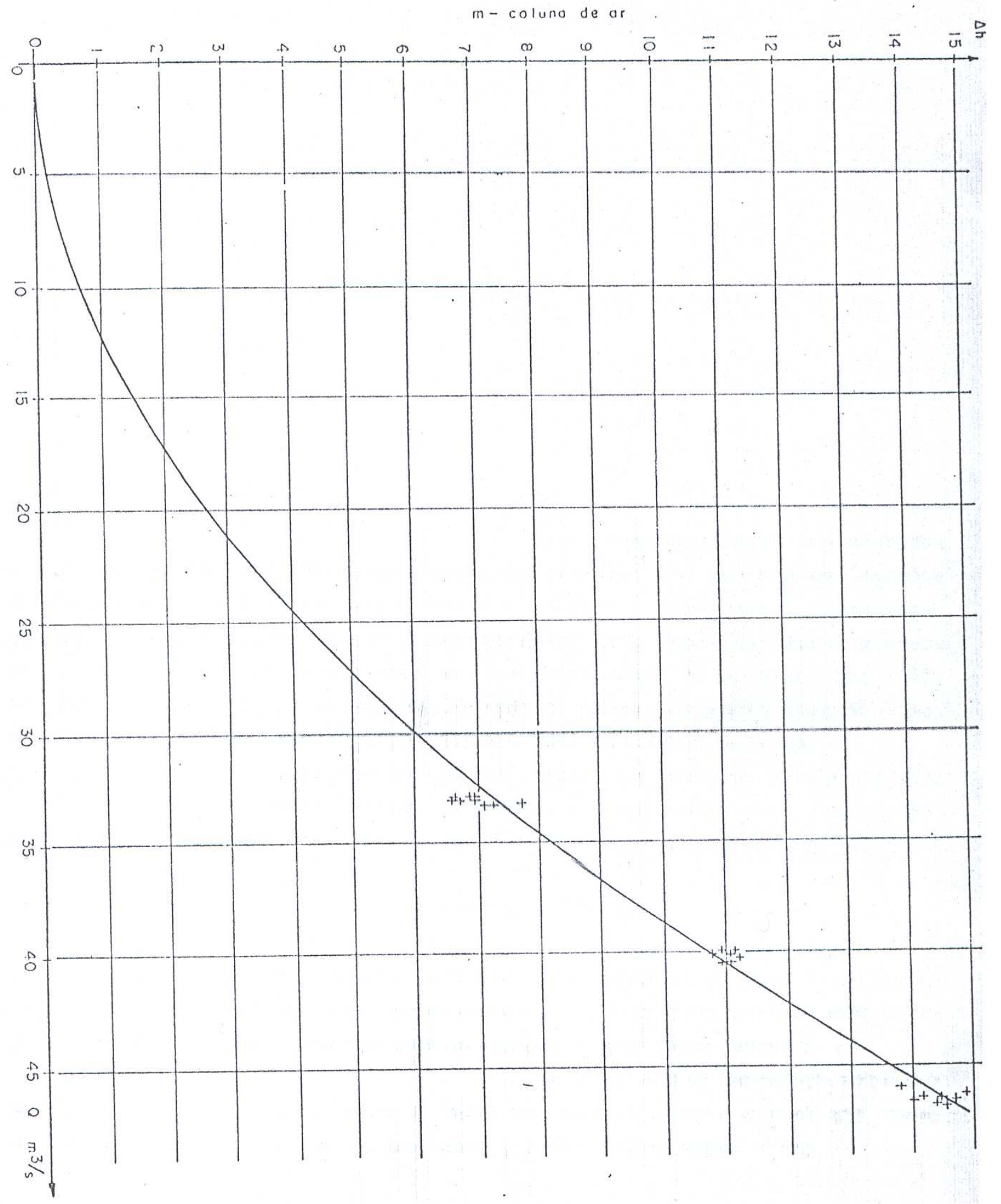

Figura 5.7: Curva das perdas de carga - Segundo Ensaio 


\section{Capítulo 6}

\section{Considerações Finais}

Neste capítulo são feitas as considerações face aos resultados obtidos pela pesquisa bibliográfica e documental, para tanto, apresentam-se considerações em função dos resultados da análise documental e entrevistas realizadas com os professores que participaram dos ensaios.

Os primeiros contatos entre a EESC e a COMASP foram intermediados pelo Prof. Ruy Carlos de Camargo Vieira (EESC) e pelo Eng. Otávio de Mattos Silvares (COMASP). Destes primeiros contatos surgiu a publicação do relatório intitulado "Ensaio do Túnel - Pré-determinação da Perda de Carga no Escoamento de Água por Circulação de Ar" (SILVARES, 1969), neste relatório ficou inteiramente descrita a metodologia a ser utilizada para o ensaio de perda de carga na circulação de ar para a avaliação das perdas quando da circulação de água no Túnel 2.

Antes do Ensaio Preliminar foram publicadas no Congresso Brasileiro de 
Engenharia Sanitária no Recife, de 27 de julho a 2 de agosto de 1969, algumas das técnicas que seriam utilizadas para a avaliação da capacidade de escoamento do túnel; entre estas publicações estão a descrição do Método Óptico (Diâmetro Hidráulico de Seções Irregulares: Determinação por Método Óptico, (ARENS, 1969)), a calibração do diafragma medidor de vazão (Determinação da Vazão de Água em Túnel por Circulação de Ar. Dimensionamento de Diafragma e seu Modelo Reduzido, (CONTIN NETO et al., 1969)) e uma descrição geral do método a ser utilizado na obtenção das perdas de carga (Determinação da Perda de Carga Hidráulica por circulação de Ar, (SANCHES et al., 1969)), neste trabalho os autores concluem que:

... o ensaio de uma canalização de água por circulação de ar é de execução relativamente simples, sendo seus resultados de grande valia no dimensionamento seguro e na construção econômica de grandes túneis de adução de água (SANCHES et al., 1969).

Essa afirmação, sem dúvida, está baseada nos resultados obtidos por Remeniéras e Bourguignon, publicados no ano de 1953 na revista francesa Le Génie civil $^{1}$, pois ainda não havia sido realizado no Brasil nenhum outro trabalho com o uso dessa metodologia. Os professores da EESC que participaram da elaboração e execução dos ensaios realizados no Túnel 2 do Sistema Cantareira e foram entrevistados para este trabalho, têm uma posição unânime quando afirmam que, na época da realização dos ensaios no Brasil e até mesmo hoje, não existia outro

\footnotetext{
${ }^{1}$ Remeniéras e Bouguignon relataram em quatro artigos publicados nos meses de março, abril e maio, tomo CXXX, números 6 ao 9, do ano de 1953, os pressupostos teóricos do método proposto por M. Remeniéras em 1941, para a determinação das perdas de carga de uma galeria a partir da circulação de ar e, além disso, apresentaram os "satisfaisants" resultados obtidos em 1948 nos ensaios das galerias da usina hidroelétrica de Pont-Escoffier (REMENIÉRAS E BOURGUIGNOS, 1953a,b,c,d).
} 
método para determinar a vazão do túnel senão através da circulação de ar.

Os professores entrevistados para a realização do trabalho aqui apresentado concordam em outra questão, a de que a assessoria prestada à COMASP, entre os anos de 1969 e 1972, teve um papel fundamental na formação do Departamento de Hidráulica e Sanemento (SHS) da Escola de Engenharia de São Carlos (EESC) ${ }^{2}$; essa assessoria foi responsável, no início do ano de 1969, pela formação de um grupo com profissionais da Hidráulica e da Mecânica dos Fluidos, mesmo antes dessas áreas terem se juntado em um único departamento com a reforma universitária. O objetivo primeiro do grupo era a realização dos ensaios, mas esse não era o principal; segundo o Prof. Ruy Vieira, formador do grupo e responsável pelos trabalhos deste, o objetivo principal era a formação de um "Departamento forte":

(...) o incentivador, se fui eu realmente, é porque eu tinha o ideal para fazer um departamento que fosse realmente um departamento diferente dos outros do Brasil, no qual a mecânica dos fluidos fosse a base tanto da hidráulica como do saneamento. E daí aceitar esse projeto e trabalhar no projeto aglutinando pessoal de mecânica dos fluidos e de hidráulica, era muito produtivo. E, era a idéia principal, a de fazer um departamento realmente forte, que fosse reconhecido nacionalmente e etc... (trecho retirado da entrevista com o Prof. Ruy Vieira).

Como cita o professor Hans, cuja tese de doutorado surgiu da solução dos problemas encontrados para a correção do coeficiente de perda de carga obtida nos ensaios, os trabalhos da COMASP, influenciaram diretamente em sua carreira

\footnotetext{
${ }^{2} \mathrm{O}$ período em que os dois ensaios foram realizados coincidiu com a reforma universitária ocorrida em todo o país em 1969. Nesta reforma as cátedras foram substituídas pela criação dos Departamentos, que deveriam reunir áreas de conhecimentos afins. O SHS foi criado pela junção de três cátedras: a de Física Técnica, a de Hidráulica e a de Saneamento.
} 
profissional:

(...)eu acho que uma das experiências marcantes assim para mim foi trabalhar em grupo. E trabalhar em grupo com um chefe, como o Ruy Vieira, que no fim eu vejo esse trabalho e a figura dos colegas influenciaram na minha formação, e é uma influência muito boa(...) (Professor Hans George Arens)

A maioria dos professores que participaram dos ensaios, estavam em início de carreira, eram recém formados pela EESC, como os professores Antonio Marozzi Righetto e Woodrow Nelson Lopes Roma, formados em 1968, Dante Contin Neto e Hans George Arens. Esses profissionais relatam em seus depoimentos que o ensaio de 1969 foi a primeira oportunidade que tiveram de trabalhar em equipe e que era grande o senso de companheirismo, e que todos estavam engajados no objetivo do Prof. Ruy Vieira, o de formar um 'departamento forte'.

Os ensaios são descritos, na maioria dos depoimentos, como um desafio:

(...)Era um desafio. Não tinha uma infra-estrutura própria. Então nós tivemos que criar isso aí, fazer um planejamento e equipamentos de rotina, estratégia, planejamento, cronograma. O departamento não lidava com essas coisas, ou seja, o departamento foi chamado para fazer uma coisa prática em um canteiro de obras e isso sai um pouco daquele "academismo"(...) (Professor Hans George Arens).

Então foi um desafio grande, porque foi um trabalho prático usando a teoria, porque naquela época, veja, em 69 essa... aqui no Brasil pelo menos, essa técnica da análise dimensional e semelhança física não era uma coisa como é hoje em dia "arroz com feijão". Ninguém tinha certeza de que isso funcionava realmente(...) (Professor Dante Contin Neto)

Este 'desafio' acredita-se que seja relativo à falta de estrutura física e tecnológica, como relata o professor Hans e a falta experiência descrita pelo professor Dante, 
na maioria dos profissionais envolvidos. Essa falta de experiência, como pode ser verificada nos depoimentos, era suprimida na confiança que a equipe colocava na pessoa do Prof. Ruy Vieira, que era, junto ao professor Marcius F. Giorgetti, um dos maiores responsáveis pela organização dos ensaios:

(...)a parte realmente intelectual, a maior, era a do Prof. Ruy Vieira, ele era o catedrático na época e realmente as idéias eram dele, ele que organizava, ele que gerenciava tudo isso(...) (Professor Hans George Arens).

(...) foi feito um modelo reduzido, foi ensaiado. O professor Marcius liderou essa parte do trabalho(...) (Professor Dante Contin Neto)

(...)O Marcius estava liderando também. Era uma pessoa muito madura o Marcius(...) (Professor Geraldo Lombardi)

A falta de estrutura física e tecnológica deve-se tanto à época em que os ensaios foram realizados, em que os computadores estavam em início de expansão tecnológica e de disponibilidade quanto, também, à falta de recursos financeiros. Como pode ser constatado nas correspondências relativas aos ensaios, grande parte dos equipamentos foram adquiridos por empréstimos de outras escolas, ou adquiridos pela COMASP, ou ainda construídos pela equipe responsável pelos ensaios. Um exemplo de que a estrutura física também era responsável por tornar os ensaios um 'desafio', no fato de que logo após o primeiro ensaio, com recursos provenientes deste, foi construído o edifício Euclides da Cunha, para abrigar a secretaria e os professores do SHS, antes sem esse espaço.

Além das dificuldades citadas acima, alguns problemas ocorridos durante os ensaios causaram uma certa 'insegurança' na equipe. Um desses problemas era o tempo de resposta nos equipamentos medidores de pressão 
(...) E então nós ligávamos os ventiladores para determinada descarga e esperávamos um bom tempo para a estabilidade tudo, mas a resposta do manômetro era muito estranha, havia mudanças, variações que não eram muito bem explicáveis e eu pelo menos entendia que a resposta deveria ser rápida porque era uma onda de pressão (...) (Professor Antônio Marozzi Righetto).

(...) Eu lembro da medição da vazão do ar no diafragma de madeira; era uma coisa imensa e era interessante porque..., como era escoamento com ar, você sentia uma leve brisa; então, como é que pode um escoamento assim, "natural"; eu estava acostumado com laboratório, modelos reduzidos, velocidades altas; velocidades que você sentia no próprio tato (...) (Professor Dante Contin Neto).

O problema ocorrido com os ventiladores, como cita o professor Righetto e já apresentado neste trabalho, se deu ao fato de que a vazão projetada para o primeiro ensaio, teve como base as curvas características fornecidas pelo fabricante dos ventiladores, mas durante o ensaio os ventiladores não obedeceram à estas curvas, o que resultou em uma vazão muito aquém da projetada para este ensaio. Para o segundo ensaio foi realizada uma verificação dessas curvas com o ensaio dos ventiladores que seriam utilizados. Com a curva obtida no laboratório da EESC, o segundo ensaio do Túnel 2 foi projetado com a real vazão que os ventiladores poderiam fornecer.

Para a medida de $\Delta h$ (perda de carga no escoamento de ar, em milímetros de coluna de água entre os extremos do túnel) foram utilizados dois manômetros tipo Betz, inseridos nos extremos do túnel; com essa instalação foi possível obter duas leituras da mesma diferença de pressão, para maior garantia na precisão dos resultados; como mostra o relatório do Ensaio Preliminar, essa configuração foi adequada.

A medida da vazão do ar por meio do diafragma foi obtida, também, 
com dois manômetros tipo Betz, ambos inseridos na tubulação, e cujas tomadas extremas foram colocados a montante e a jusante do diafragma. Essa medida sofreu uma correção devida à diferença entre as massas específicas do ar à pressão atmosférica padrão (para a qual a curva de calibração do diafragma foi feita) e a massa específica do ar a montante do diafragma. Como para a estabilização das leituras eram necessários em média 90 minutos, devido ao comprimento da tubulação utilizada para ligação do manômetro óptico às extremidades do túnel, foram consideradas apenas os pontos anotados depois de 90 minutos.

A curva característica de perda de carga no túnel $(\Delta h \times Q)$ obtida do escoamento de ar, foi utilizada para a previsão do escoamento da água utilizandose a vazão $Q$ em $\mathrm{m}^{3} / \mathrm{s}$ e $\Delta h$ em metros de coluna de ar para o escoamento de ar e $Q$ em $m^{3} / s$ e $\Delta h$ em metros de coluna de água para o escoamento da água.

O coeficiente $\lambda$ da perda de carga do túnel só poderia ser calculado por trechos de seção aproximadamente uniforme, mas como a medida da perda de carga, em ambos ensaios, foi realizada entre os extremos do túnel, este coeficiente foi determinado por trechos, por estes terem características bastante distintas uns em relação aos outros.

Muitos diferentes métodos e instrumentos têm sido usados para construção de túneis, tanto no Brasil quanto em outros países, isso limita esta pesquisa a apresentar outros ensaios semelhantes a estes realizados no Túnel 2 do Sistema Cantareira e na hidroelétrica de Pont-Escoffier. São dois os fatores limitantes. O primeiro é que muitas empresas responsáveis por obras desse tipo, desenvolvem suas próprias técnicas, mas não têm publicado seus detalhes. Segundo, com o 
advento da computação e a grande diversidade de equipamentos que realizam as medições feitas nos ensaios, não é possível, neste trabalho, fazer uma completa análise de cada sistema possível de ser utilizado para realizar um ensaio com circulação de ar nos dias de hoje.

O Método Óptico, por exemplo, desenvolvido para a medição do diâmetro hidráulico do túnel e determinação da rugosidade relativa proporcionou agilidade e versatilidade no levantamento das características do túnel. Até o ano de 1969, nenhum outro método, com tais características, era conhecido por seus idealizadores. Hoje porém, tornou-se obsoleto com a utilização do laser nos equipamentos topográficos atuais, como a estação total. Os quilômetros de mangueiras usados nos ensaios do Túnel 2, podem ser substituídos por sensores eletrônicos, cuja maior parte das conexões e transmissão de dados podem ser feitas não mais com fios, mas por ondas de rádio. 


\section{Apêndice $A$}

\section{Entrevistas}

\section{A.1 Entrevista com o Professor Hans George Arens}

Professor Hans, nossa entresvista com o Sr. refere-se aos ensaios da perda de carga realizados no Túnel 2 do Sistema Cantareira.

Professor Hans: Hemerson, eu não me lembro mais. Você terá de me ajudar.

Sem problemas, Professor. No início da coleta dos dados para nossa pesquisa, encontramos dois trabalhos de sua autoria relacionados aos Ensaios: um artigo sobre o Método Óptico e a sua tese de doutoramento, sobre a correção do coeficiente de perda de carga devido à presença de água no fundo do túnel.

Professor Hans: Este trabalho, a tese, foi realizado depois do trabalho com o túnel, mas a idéia surgiu naquela época, quando estávamos realizando o tra- 
balho. O relatório dos ensaios foi entregue com os coeficientes de perda de carga estipulados conforme a bibliografia e depois pelo bom senso, digamos. Foi estipulado este coeficiente e calculado. Na época, o chefe do departamento era o Prof. Ruy Vieira, e ele quem fez esse relatório. E anos depois, não sei nem quanto tempo depois, foi que eu comecei a trabalhar, pensando no doutorado. Naquela época se fazia doutorado em época muito posterior a de vocês, se esperava mais. Então, anos depois que eu cheguei e me interessei nisso e aproveitei esse tema para fazer meu doutorado. Quer dizer, o resultado não foi aplicado ao relatório. Acho que eles apenas sugeriram essa correção.

Sim, os relatórios sugeriram essa correção...

Professor Hans: É que eu não me lembro mais das datas, a tese, eu acho, foi depois do relatório. Eu não me lembro mais.

Sua tese foi defendida em 1972 e os ensaios terminaram também em 1972. O primeiro foi em 1969 e o outro em maio de 1972, foram próximos... Bem, no primeiro ensaio, o Sr. escreveu sobre o Método Óptico...

Professor Hans: Me lembro...

O Sr. se lembra da idéia original?

Professor Hans: A idéia primeira é que, dentro desse ensaio pedido pela COMASP na época, eu acho, constava o levantamento da geometria do túnel, e 
chamavam de "as built", ou seja, foi feito um projeto, foi feita a execução desse projeto, e algumas coisas devem ter sido mudadas durante a construção desse túnel. Então ele foi mudado. Então eles pediram, como estavam quase terminando a execução do túnel, pediram que o departamento fizesse o levantamento das dimensões, das geometrias das seções, para eles terem uma idéia, pois depois iam encher de água o lago e ficaria bem mais complicado.

Bem, eu estava lendo um jornal, e vi um túnel que estava sendo construído. Acho que era início do metrô de São Paulo. E aí eu vi na fotografia, na frente do jornal, aros formados pelas lâmpadas utilizadas para o pessoal trabalhar e uma série de circunferências iluminadas, mostrando a profundidade daquele túnel. Eu gostei da fotografia, do seu visual. A luz delineava a seção do túnel. E aí eu aproveitei essa idéia e falei com o professor Ruy Vieira, eu era muito jovem na época. Eu disse: porque ao em vez de medirmos as seções na base da trena ou de outros jeitos, pois já tinham pensado nisso, eu sugeri o seguinte, a gente pode fazer o levantamento das seções e diâmetro hidráulico fotograficamente. Por que não? Então faz fotograficamente, amplia isso e guarda as fotografias. E ele achou a idéia boa. E como nós tínhamos um fotógrafo de mão cheia trabalhando aqui no departamento, o Paulo Pires, ele também entrou nessa equipe, passou a trabalhar com a gente, e ele sugeriu o mecanismo. E acabamos fazendo esse chamado Método Óptico naquela época.

O "Método Óptico" teve duas fases: a primeira, onde era usado lâmpadas para produzirem o feixe luminoso para ser projetado na parede da galeria e uma 
segunda, em que foi usado um flash. O senhor consegue lembrar como foi essa mudança?

Professor Hans: As lâmpadas... As lâmpadas não foram uma boa coisa. A gente carregava uma bateria pesada junto, uma bateria. E as lâmpadas eram de 12 volts, qualquer coisa assim, e a iluminação era insuficiente. O tempo de exposição tinha de ser grande e manusear dependia de automóvel... era pesada e tudo mais, então se mostrou... Foi bom, mas podia ser melhorado. Daí o Paulo Pires sugeriu o flash.

Então para o primeiro ensaio, o método óptico foi realizado com essas lâmpadas?

Professor Hans: Eu já não sei se ele foi completado com essas lâmpadas. Mas depois com o flash, os resultados alcançados foram melhores e o trabalho muito mais rápido. Para esse sistema com o flash foi montado sobre uma estrutura em que trabalhávamos com a máquina fixa. Em vez de chegarmos, montarmos o flash, o operador se afastar e tirar a fotografia, montamos uma estrutura e colocamos em uma extremidade o flash e na outra, mantendo uma distância focal, a máquina, com essa estrutura sobre o trilho, e assim ficava tudo automatizado para irmos tirando as fotografias. Eu não me lembro mais. Você tem de me ajudar.

Correto... Voltando um pouco à história do túnel. Ele foi projetado e executado para uma vazão de $22 \mathrm{~m}^{3} / \mathrm{s}$. Depois houve uma mudança no projeto 
da ETA, que passaria a tratar $33 \mathrm{~m}^{3} / \mathrm{s}$. Resolveram assim realizar o rebaixamento do piso em toda a extensão da galeria. Iniciaram esse rebaixamento em duas frentes de trabalho, uma de montante para jusante e a outra de jusante para montante. Em determinado momento, passaram a questionar se haveria a necessidade de rebaixar o piso do túnel em toda a sua extensão e ainda, se a altura do rebaixamento seria suficiente para a nova vazão. Nesse impasse é que a então Cátedra de Mecânica dos Fluidos foi contratada para verificar qual era a vazão que o túnel seria capaz de aduzir naquela situação em que se encontravam as obras e, se necessário, quanto mais deveria ser rebaixado. Dependendo do parecer de vocês, continuariam ou não as obras de rebaixamento. Como foi para o senhor, que estava em início de carreira, participar dessa equipe, desses ensaios?

Professor Hans: Bem, eu estava em inicio de carreira. Eu estava realmente em inicio de carreira e tinha o chefe da equipe que era o Sr. Ruy Vieira. Eu não sei de outros colegas nossos. Então era um grupo mais ou menos, era um grupo trabalhando. Então, dividiu-se cada um trabalhando em uma determinada função dentro daquela equipe que estava tratando desse programa. Agora a parte realmente intelectual, a maior, era a do Prof. Ruy Vieira, ele era o catedrático na época e realmente as idéias eram dele, ele que organizava, ele que gerenciava tudo isso, inclusive os contatos em São Paulo. Então realmente, o problema em que me lembro era mais ou menos conferir, ver se realmente com aquela geometria, uma parte rebaixada e a outra sem rebaixar, se atendia à vazão dos $33 \mathrm{~m}^{3} / \mathrm{s} \mathrm{com}$ o que eles alteravam. Eu não me lembro nem mais do laudo final. 
A conclusão do primeiro ensaio foi que era preciso escavar mais ou menos um quilômetro apenas...

Professor Hans: Claro. Era pouca coisa.

Sim, menos que o previsto pela empresa que estava escavando. Com o ensaio, deixou-se de escavar quase $2000 \mathrm{Km}$ e meio, ou seja, economizou o tempo e dinheiro. O segundo ensaio...

Professor Hans: É que eu não me lembro agora do segundo ensaio, você acredita? Para mim houve um ensaio só, você está me falando que foram dois ensaios...

É. No primeiro ensaio, o relatório não justifica quem trabalhou. No relatório do segundo ensaio há uma relação dos componentes de cada equipe que trabalhou no ensaio. O Senhor participou com o Ruy Vieira que era a terceira equipe. Foram quatro equipes: uma no emboque, outra no desemboque e duas no interior...

Professor Hans: O segundo ensaio?

O segundo ensaio. O senhor participou do segundo ensaio também, os dois foram muito semelhantes...

Professor Hans: Eu acho que sim. 
O segundo ensaio tenho ele mais detalhado, pois o relatório que vocês fizeram, com mais tempo que o primeiro, ficou mais detalhado e contou com toda uma experiência do primeiro ensaio.

Professor Hans: É, realmente é uma surpresa os dois ensaios. Eu não me lembro de tudo, então como eu estou me lembrando não sei se foi no primeiro ou no segundo, provavelmente no segundo foi o mais recente, então eu realmente não me lembro do primeiro. No segundo, aí eu já não sei, é aquele negócio, porque como problema era maior, eu não sei se nós chegamos a corrigir isso, o primeiro ensaio no segundo ensaio, ou se nós aprendemos no segundo ensaio foi o problema dos ventiladores. Então era uma vazão com uma descarga de ar pequena, acho que no primeiro ensaio, então ficou um ensaio que deixou a desejar por causa disso, porque a velocidade do ar era muito baixa e as medidas foram baixas. Eu acho que no segundo ensaio isso foi corrigido.

No primeiro ensaio, os ventiladores eram para ser emprestados, não sei se o Sr. se lembra, eram de outra empresa...

Professor Hans: É eu me lembro.

Só que a empresa dona dos ventiladores, na hora dos ensaios não pôde emprestá-los, porque estavam sendo utilizados. Com isso a COMASP comprou três ventiladores, como os especificados no projeto, e vocês utilizaram as curvas 
características fornecidas pela empresa que vendeu os ventiladores...

Professor Hans: Dos três ventiladores.

E durante o ensaio, os ventiladores não forneceram a vazão projetada, ou seja, não responderam às curvas que o fabricante forneceu...

Professor Hans: Do primeiro ensaio?

Isso. Do primeiro ensaio. No segundo vocês obtiveram a curva de um dos ventiladores através de um ensaio no laboratório...

Professor Hans: No ventilador. Então foi um ensaio, eu acho que foi feito no primeiro com uma densidade muito baixa, então teve uma vazão muito pequena e maior no segundo. Então, agora que eu estou me "situando" entre o primeiro e o segundo ensaio.Então eu acho que a grande diferença entre o primeiro e o segundo, aquilo que tecnicamente influenciava sobre os resultados foi à velocidade do ar. Com uma velocidade muito baixa e diferença de pressão muito baixa, e no segundo ensaio isso ai foi melhorado com três ventiladores e fazendo a instalação desses três ventiladores, que era no desemboque do túnel, de uma forma melhor. A vedação... Colocou-se realmente uma parede de madeira de compensado e tudo mais com estrutura bem reforçada, e no primeiro ensaio não se deu tanta ênfase a essa colocação dos ventiladores, a curva tinha sido corrigida realmente, e os ventiladores foram melhor colocados. Então isso foi uma grande diferença que se obteve entre o primeiro e o segundo. E no segundo ensaio, também a calibração, eu não sei qual a média dos ângulos ou o diafragma. 
Esse diafragma ele era colocado em uma seção que não era redonda; novamente em todas as curvas, o diafragma e o medidor de vazão, elas são publicadas em geometria circular e esse túnel não, realmente ele fugia da geometria circular. Então se fez um estudo aqui no laboratório, por um colega meu que provavelmente você vai a não entrevistar, que é o Dante. Então eu acho, eu e o Professor Dante, que foi ele que foi mais ou menos, eu estou achando isso, Hemerson, que foi ele o responsável, foi a figura principal para fazer os ensaios de um modelo reduzido no laboratório. E eu não sei se isso tinha feito no primeiro, mas quem vai te responder isso com muito mais autoridade e clareza é o Professor Dante.

Eu conversei um pouco com o Dante e ele me falou que também estava iniciando a carreira e que era grandiosa a obra e que ele até se assustou quando ele viu o tamanho das bombas. Era um desafio para a equipe este projeto. O senhor me diz a respeito?

Professor Hans: Não, realmente o que eu lembro de muitos detalhes. É que eu trabalhei no início, a equipe que eu trabalhei foi aqui em São Carlos, trabalhava com caneta, papel, máquina de calcular e laboratório; em termos acadêmicos. Estava trabalhando aqui em casa onde eu conhecia o território. Agora eu lembro da instalação dos ventiladores, a escolha dos ventiladores e a visita à obra. Bom, então o Dante chegou e entrou nessa equipe, na obra para fazer as medidas, resolver os problemas com a construtora para dar o desenho desse túnel: desemboque, geometria e altura para que a gente projetasse essa parede para colocar os ventiladores. Então eu acho que até com a ajuda do Professor Gava. O Gava tra- 
balhava com maquinas hidráulicas, bombas e ventiladores. Eu lembro que o Dante foi o primeiro a ir a São Paulo, visitar o canteiro de obras e olhar e ver o tamanho do túnel e o tamanho da casa de bombas. Então ele voltou impressionado, eu me lembro, porque ele voltou da idéia e da vida acadêmica para a prática, então ele ficou alguns dias em São Paulo num canteiro de obras e tratou com engenheiros de obra. Então os engenheiros de obra, para eles no início eles achavam que para fazer um ensaio estava atrapalhando a obra deles. Então surgia assim um conflito entre os interesses nossos em chegar, tomar medida, fotografar, percorrer o túnel e tudo o mais, levantar detalhes sobre isso; e eles estavam querendo fazer a obra, tinha um plano de entrega, um plano de serviço e muitas vezes tinha que interditar alguma coisa. Então surgiu o conflito. Então o Dante sentiu isso, ele voltou e disse que esse era o problema: "que nós estávamos querendo fazer e nós estamos atrapalhando eles lá"; então surgiu esse problema aí. Ele entrava em contato em São Paulo, com a COMASP, com a gerência e eles apaziguavam os dois lados. Então, essa foi a diferença do Dante que eu me lembro assim na época.

O que o professor Dante disse, é que era tudo muito grandioso, ele não se sentia muito seguro nas inferências que eles tinham de fazer, durante os cálculos e durante o relatório; tinham que dar um parecer e era uma coisa que vocês nunca tinham feito com uma dimensão grande.

Professor Hans: Grande. Exato. Ai, entrou toda a equipe. Acho que mais velho era o professor Marcius e o professor Gava, eu era mais jovem, o Dante mais jovem ainda e outros colegas; mas quem realmente resolvia a parte 
técnica, de cálculo e tudo o mais. A responsabilidade de fazer relatório final era o Prof. Ruy Vieira, ele era o chefe geral e nós éramos os auxiliares. Ele delegava responsabilidade para aquilo que ele achava, isto é, entre os elementos, ele escolhia aqueles que resolviam essa parte ou aquela; no laboratório ou na parte prática lá. E aí ele achou que o Dante, e eu acho também que era uma questão de aprendizagem, fosse ao canteiro de obras; ele foi o primeiro e ficou impressionado e trouxe essa idéia para o resto da equipe, aí nós nos enquadramos.

Vocês, fora o professor Dante, estiveram no canteiro apenas para os ensaios?

Professor Hans: Não. Nós fizemos visitas ao túnel antes em dias anteriores aos ensaios para ver como nós íamos colocar os manômetros, expor material e fazer uma organização. A equipe se ficava aqui ou não, o sistema de comunicação que nós iríamos usar. Eu me lembro de uma ou duas visitas anteriores. Não foi assim chegar e entrar no túnel. Aquela própria água que eu utilizei aqui para fazer o meu doutorado no laboratório; a água do túnel é diferente do doutorado, simulando o túnel com gesso a geometria de túnel para colocar água era uma coisa, agora o túnel real era outra coisa. Agora, quando todo mundo entrou no início do túnel era água, um palmo de água; depois um metro de água então na primeira medida, os dois palmos de água, a turma andava devagar para não entrar água na bota (usávamos capacetes e tudo mais), mas depois na segunda ou terceira visita já deixava entrar água, já enfrentava uma água legal, fazia parte. E aí você se acostuma, é claro que os engenheiros da obra e o pessoal de apoio ali da obra que 
trabalhava com a gente, já estava acostumado, pois eles ficavam na água direto. Tinham um barco do corpo de bombeiros ou qualquer coisa assim. Porque tinha lugar lá que só de barco. Porque tinha também que levar equipamentos, então na água não seria possível. Então foi realmente na época um acontecimento.

Eu fui pesquisar isso no seu currículo e eu não o encontrei na plataforma Lattes, acho que ele não deve estar lá. Eu gostaria de ver se, fora os artigos da época e a sua tese de doutorado, se o senhor havia publicado mais alguma coisa a respeito...

Professor Hans: Não. Não, acho que não. No túnel foi uma época interessante, mas depois ele caiu no esquecimento, mas depois o departamento mudou, não sei o que que... o departamento mudou... o departamento cresceu muito com esse trabalho do túnel; ele trouxe verbas para o departamento, ele trouxe uma continuidade da equipe que trabalhou, por todas essas dificuldades e foi bom para a equipe do Ruy Vieira; trouxe dinheiro e o departamento inteiro depois do ensaio teve uma época de progresso muito grande. O prédio e tudo o mais. Então eu lembro que isso aí foi um acontecimento importante, foi um passo muito grande para o departamento. Foi um fato que gerou um crescimento para o departamento, acho eu. Mas depois tudo isso passou, esqueceu e outras coisas começaram a surgir. Então realmente, não houve utilidade nos trabalhos que cada um fez durante o ensaio e não houve continuidade e não importou em nada.

O senhor consegue explicar as dificuldades de espaço, de material, de re- 
cursos que tinham antes?

Professor Hans: É, eu acho que a dificuldade é... que eu tenho que voltar para a época, para ver as dificuldades. As dificuldades da época é que era tudo mais complicado, então é difícil eu te dizer qual foi a maior dificuldade.

... recursos tecnológicos como máquinas de calcular...

Professor Hans: Não, os cálculos não. Os cálculos foram do Ruy Vieira e ele estava amontoado, o problema não foi esse. Por que as dificuldades eram todas, digamos: as medidas de pressões baixas, a diferença de pressão medida ao longo do túnel, as pressões eram muito baixas. Não tínhamos manômetros para isso, então a gente tinha que arrumar recursos fora, tinha que viajar para Itajubá, pegar equipamentos emprestados para medir isso aí, então foi realmente fazer os preparativos sem que o departamento tivesse uma infra-estrutura própria, já montada para fazer o trabalho decidido. Era um desafio. Não tinha uma infraestrutura própria. Então nós tivemos que criar isso aí, fazer um planejamento e equipamentos de rotina, estratégia, planejamento, cronograma. O departamento não lidava com essas coisas, ou seja, o departamento foi chamado para fazer uma coisa prática em um canteiro de obras e isso sai um pouco daquele "academismo".

Era diferente, no laboratório tudo funciona...

Professor Hans: Exatamente, e você tem mais tempo de escolher equipamentos disponíveis, a cobrança de horários e relatórios e isso não é tão flexível e 
tudo o mais, e nós entramos em contato com um mundo exterior, não aqui dentro da escola. E isso foi assim um aprendizado, para todos eles, para todos os que trabalharam.

E que influência teve na cadeira do senhor a experiência com esse trabalho?

Professor Hans: Uma foi que surgiu o doutorado, mas eu acho que uma das experiências marcantes assim para mim foi trabalhar em grupo. E trabalhar em grupo com um chefe, como o Ruy Vieira, que no fim eu vejo esse trabalho e a figura dos colegas influenciaram na minha formação, e é uma influência muito boa. Então comparando hoje em dia com pessoas que são selecionadas por concurso do departamento e vêm trabalhar tanto no nosso como em outro, eles começam a trabalhar e têm uma aparência de liberdade maior de definir o campo de pesquisa, cada um escolhe o campo de pesquisa e operar, fazer trabalhos com isso, e na época não; o chefe era o Sr. Ruy Vieira e ele era realmente o líder, tinha liderança total, era um ótimo chefe e isso ai foi uma vantagem para mim. Trabalhar nessa forma, ou seja, a figura do chefe me influenciou muito, era uma época mais antiga onde o chefe fazia e criava uma escola com um jeito de pensar um jeito de trabalhar, um jeito de resolver o problema. E isso... ele atuou sobre o grupo inteiro. E isso aí, eu penso hoje que foi uma grande influência. Não o ensaio propriamente dito "o ensaio", mas o grupo e o chefe.

E depois vocês tiveram outras oportunidades semelhantes para trabalhar em grupo? 
Professor Hans: Não sei, eu não me recordo. Mas trabalhar em grupo como nós trabalhamos neste túnel, eu acredito que não, nada que assemelhou. Mas se houveram algumas coisas; o Marcius deve saber melhor; mas depois houve alguns ensaios fora que eu mesmo não participei, mas não houve a formação de um grupo acho eu, equivalente ao grupo formado para esse ensaio.

Houveram outros ensaios relacionados ao Sistema Cantareira, como o ensaio da chaminé de equilíbrio e das válvulas dissipadoras...

Professor Hans: Eu não participei, assim, ativamente. Nem da chaminé de equilíbrio e nem das válvulas. Eu lembro delas que era preciso ensaiá-las, o modelo das válvulas que foram ensaiados aqui neste laboratório, mas sem a minha participação. Eu lembro, me lembro das fotos, dos relatórios e tudo o mais. E da chaminé de equilíbrio eu não me lembro bem, eu lembro por ter ouvido você falar da chaminé de equilíbrio. Não se foi feito lá, tem alguma coisa a respeito?

Então, tem pouca coisa da chaminé. Tem mais da válvula dissipadora que foi ensaiada aqui.

Professor Hans: Eu lembro da cobertura da chaminé, mas aí realmente... Porque foi pouca coisa executada não é?

Não tenho relato. O senhor possui algum material relativo aos ensaios?

Professor Hans: Eu tinha muita coisa e no fim foi tudo perdido. Per- 
dido não, eu separei e não sei aonde é que foi parar isso aí. Então nesses últimos anos, eu estava fazendo uma limpeza em casa no escritório, acho que tudo isso aí já foi pelo espaço.

Conseguimos encontrar os filmes que foram feitos e eles estão sendo restaurados, estão em São Paulo, deve estar chegando, daí eu gostaria de convida-lo...

Professor Hans: Ah! Mas eu quero. Sem problema nenhum. Como é? Eles conseguem restaurar, tem técnicas para isso?

Esses filmes estavam lá no CRHEA, em um depósito. Durante a busca, um funcionário lembrou-se de ter visto os filme e entregou-os para nós. Só que os filmes não foram bem conservados, eles estavam ressecados. São três rolos. Um rolo foi possível projetar e os outros dois precisaram passar por um processo de restauração, para depois serem convertidos para o formato DVD.

Professor Hans: É, eu cheguei a ver partes desse filme, eu me lembrei agora.

Providenciarei uma cópia para o senhor

Professor Hans: Eu agradeço muito, gostaria de recordar mais daquele trabalho. Bom, acho que é isso, Hemerson, se eu recordar de mais alguma coisa eu te procuro, você me procura.... 
Sim, com certeza e muito obrigado pelo depoimento. 


\section{A.2 Entrevista com o Professor Dante Contin Neto}

Professor Dante: Como será? Tipo pergunta e resposta? Se precisar você vai encaminhando?

Sim. Eu não tenho um roteiro elaborado, é uma entrevista não-estruturada. Assim, se necessário eu vou encaminhando. O Sr. entrou na USP em 1967, poderíamos começar por essa fase?

Professor Dante: Comecei a trabalhar na USP em outubro de 1967. Antes eu trabalhava em São Paulo. Trabalhava na Pirelli, a fábrica de pneus, em Santo André. E aí meu pai adoeceu, ele morava aqui em Ribeirão Bonito, ele adoeceu. Só tinha eu e uma irmã que morava lá em São Paulo. Então eu falei: acho que para mim é melhor eu voltar para o interior. Então eu vim fazer uma visita aqui à EESC em São Carlos, na Escola de Engenharia. E foi aí que eu encontrei um amigo meu, um colega, quase que colega de turma, que foi professor na USP e se aposentou lá: o "DARIO BENINI"; conversamos e tal e ele falou: eu estou cotado para assumir um posto de professor lá na Elétrica, mas eu fiz uma entrevista na Física Técnica com o Prof. Ruy Vieira e ele me disse que está precisando de docente lá. Então eu fui até lá. Conversei com o Prof. Ruy Vieira e acabamos... a gente acabou se entendendo. Deu certo. Ele me passou um trabalho que ele estava fazendo uma publicação sobre "O mercado produtor de bombas no Brasil", bombas hidráulicas. E foi ai que ele falou: "vai fazendo esse trabalho ai", acho que era um trabalho de revisão de curvas de bombas; ele fez um 
apanhado das firmas produtoras de bombas hidráulicas no país. Aí eu esperei uns três meses até sair a vaga e ai eu fui contratado: em outubro de 1967, na antiga Física técnica sob a batuta do Prof. Ruy Vieira. Eu me formei em 1966, então nessa época eu tinha uns 23 anos, eu era bem "novinho".

Só graduado ainda?

Professor Dante: Sim, só graduado. Naquele tempo não tinha ainda mestrado aqui na USP São Carlos. Acho que tinha em São Paulo, mas aqui não tinha.

O Sr. graduou-se onde?

Professor Dante: Aqui também... Retornei à casa...

E para esse trabalho do túnel, o Sr. se lembra como foi seu ingresso nele?

Professor Dante: Esse foi um trabalho que envolveu todo o departamento. Chamava-se: Departamento de Física Técnica. Eu acredito que o Prof. Ruy Vieira foi convidado a desenvolver esse trabalho por intermédio do professor Tufi Mamed da Poli; então houve um planejamento muito grande em torno disso ai, porque todos sentiam que o trabalho era grande. Um trabalho de grande responsabilidade. E grande também em tamanho. Então, o Departamento inteiro foi acionado, claro que você não era obrigado a participar, mas a adesão foi quase que unânime, todos quiseram participar porque era um trabalho muito 
bonito. Para mim, foi muito interessante porque eu era muito novo ainda, mas já tinha uma idéia de que a universidade era mais; ela tratava mais de questões teóricas e menos da prática da engenharia, sujar a mão como diz a turma, "pegar na massa". Então foi um desafio grande, porque foi um trabalho prático usando a teoria, porque naquela época, veja, em 69 essa... aqui no Brasil pelo menos, essa técnica da análise dimensional e semelhança física não era uma coisa como é hoje em dia "arroz com feijão". Ninguém tinha certeza de que isso funcionava realmente. Então, quer dizer, ninguém no caso eu que estava começando. Então foi um desafio muito grande, ainda bem que a equipe que era unida, uma equipe que já estava formada, sob uma liderança que é o Prof. Ruy Vieira. O Professor Ruy Vieira foi quem "encabeçou" o trabalho, ele era o chefe de departamento. Naquela época, chefe de departamento era uma autoridade. O regime aqui da USP era bastante semelhante à hierarquia militar, que é até hoje, tinha que seguir. Hoje é mais aberto, hoje não tem muita hierarquia, não estou criticando, não estou dizendo se é melhor ou pior, mas mudou. Como tem de mudar mesmo. Então o Prof. Ruy Vieira era o líder da equipe e todos os professores do Departamento, ou quase todos, colaboraram, participaram. Tinha o professor... basicamente, eu acredito que o braço direito do Prof. Ruy Vieira foi o professor Hans George Arens, depois os outros professores todos: O professor Marcius Giorgetti, acho que o Woodrow já estava lá no Departamento também, eu, não sei se o pessoal da Hidráulica propriamente dita também estava; o Righetto; o Geraldo Lombardi que era da Física Técnica. Existia o Departamento de Física Técnica, do Prof. Ruy Vieira e o de Hidráulica, eram separados os dois, um não tinha nada em 
haver com o outro. Física Técnica mexia mais com fluidos não água, tipo: fluidos de lubrificação e mais máquinas, menos obras hidráulicas do tipo barragens, vertedouros, era mais a parte de máquinas térmicas, que tinha muito; máquinas, maquinário hidráulico. Então, quem mais participou?... O professor Geraldo Lombardi, sem dúvida; o professor Reynaldo Gava, também participou da equipe; o professor Woodrow que eu já falei; que eu me lembro era mais ou menos isso.

No primeiro ensaio, o Sr. publicou um artigo com o professor Marcius sobre a calibração do diafragma...

Professor Dante: Sim, calibramos um modelo reduzido. O diafragma não tinha... O túnel não tinha uma seção regular, acho que tinha uma seção em ferradura; então é... inclusive como era um trabalho pioneiro, original, nós optamos por fazer um ensaio de modelo reduzido, para ver a influência da não regularidade... o fato de não ser circular a seção, fizemos, se eu não me engano, um túnel em gesso e medimos esse modelo reduzido em laboratório. Se eu não me engano, foi com ar mesmo, não foi com água. Levantamos a curva do diafragma; acho que não interferiu muito o fato de não ser circular a seção. É que são 37 anos, se esquece um pouco. Mas bem, foi feito um modelo reduzido, foi ensaiado. O professor Marcius liderou essa parte do trabalho.

No primeiro ensaio vocês construíram um modelo reduzido da seção do túnel em gesso, e ensaiaram o diafragma modelo, nesse trecho que representava o local onde seria instalado, no túnel, o diafragma. No segundo ensaio, vocês 
também ensaiaram um modelo reduzido do túnel com o diafragma, mas não em gesso, em uma manilha de cimento.

Professor Dante: Sim, como no primeiro ensaio, a não regularidade da seção não influenciou muito nos resultados, para o segundo utilizou-se dessa manilha.

Foram recuperadas partes do filme gravado durante os ensaios, esse filme mostra o senhor trabalhando durante os ensaios do túnel. O que o senhor pode me falar sobre os ensaios no túnel?

Professor Dante: Dentro do túnel... Bom, foi feito um planejamento, porque o túnel tinha quase $5 \mathrm{~km}$ de extensão; então havia a necessidade de comunicação entre os membros das equipes de montante, de jusante, dentro do túnel; então foi feito um planejamento dessa parte de comunicação. Se eu não me engano, teve a participação de soldados do exército com materiais de rádiocomunicação. O túnel era, e é, uma obra de engenharia de grande porte e em vários trechos não tinha luz no túnel, tinha de ser iluminação artificial e água, água até a cintura, em vários trechos você tinha de atravessar o túnel com água até na cintura; isso causava uma certa preocupação, até mesmo quanto a segurança pessoal, era uma coisa que eu nunca tinha passado por isso. Bom, mas o que nós sentíamos, pelo fato de sermos uma equipe, que já estava acostumada a trabalhar juntos, sentíamos segurança do ponto de vista técnico, quer dizer, a preocupação, talvez um pouco, quanto à segurança pessoal. Mas as atividades a serem desenvolvidas, que foram desenvolvidas lá dentro, estavam previstas já. 
Então isso trouxe segurança para nós.

(Pausa)

Professor Dante: Muito bem, onde estávamos mesmo?

O Sr. estava falando de sua experiência dentro do túnel...

Professor Dante: Eu me lembro da medição da vazão do ar no diafragma de madeira; era uma coisa imensa e era interessante porque... como era escoamento com ar, você sentia uma leve brisa; então, como é que pode um escoamento assim, "natural"; eu estava acostumado com laboratório, modelos reduzidos, velocidades altas; velocidades que você sentia no próprio tato, você sentia não era um vento, uma aragem em laboratório; mas lá no túnel era; então, pesávamos: "será que isso vai dar certo mesmo?", "será que vamos conseguir medir e transformar isso em escoamento de água?" Então para mim, que estava começando, foi uma experiência muito bonita, porque era uma coisa... uma novidade, um ineditismo e que depois passamos para água; essa passagem foi muito bonita; foi o segundo estágio; foi a análise dos resultados. Dentro to túnel mesmo, vamos dizer assim, foi uma sensação muito gostosa, que era trabalhar em um meio um pouco inóspito; trabalhar com coisas grandes e diferentes, coisas que para mim foi uma honra, foi assim, eu achei muito benéfico ter a oportunidade de trabalhar nessa obra aí, porque eu aprendi muita coisa, aprendi muito, quer dizer, a visão de uma obra grande, de grande porte, é você encarar isso aí como um trabalho 
de engenharia e propor uma solução que no fim foi correta, tecnicamente correta. Algumas coisas que talvez, não sei se é essa a ordem que gostaria, mas estou lembrando e preciso falar, é uma coisa que eu achei muito interessante também, que eu fiquei impressionado foi aquele método óptico, para determinar a seção e principalmente para conhecer a rugosidade, a rugosidade equivalente para você entrar na fórmula de cálculo de perda de carga, o famoso " $€$ ", o túnel, boa parte dele, era obtido por dinamitação, era dinamitado; então a rugosidade era completamente irregular, variava de $5 \mathrm{~cm}$ a $50 \mathrm{~cm}$, as entranças, as saliências que a detonação causava. Não tinha aquelas máquinas que fazem o metrô hoje. Então foi desenvolvido, na minha memória quem fez, foi o professor Hans. Uma pessoa que colaborou muito aí, que era técnico, foi o Paulo Pires; eu me lembro porque foi feito um método óptico, que foi chamado de método óptico ou fotográfico, não me lembro; que era feito a fotografia, tinha um aro, como que eu diria?... uma "bolacha", como se fosse uma pizza oca e tinha uma janelinha, uma fresta, e dentro dessa "pizza", vamos falar assim, tinha uma luz; então ela emitia uma luz e a luz marcava a parede do túnel, e você fotografava, com uma distância determinada, conhecida, você fotografava aquele feixe de luz que riscava a parede do túnel e depois você transformava aquilo, na devida escala, e obtinha uma boa medida da rugosidade do túnel. Isso foi uma coisa muito interessante, porque depois você via a foto, você via fotografando o local, depois você via a foto revelada e você percebia que aquilo realmente iria funcionar, foi muito interessante isso aí, eu nunca tinha visto anteriormente; depois foi testado em laboratório e foi confirmado a precisão do método. 
No primeiro equipamento desenvolvido para o método óptico, para a formação do feixe de luz, eram utilizados doze lâmpadas, mas estas aqueciam muito o equipamento, e a bateria tornava-o muito pesado e desconfortável para ser utilizado no ensaio; foi então que o Paulo Pires sugeriu que no lugar das lâmpadas fosse utilizado um flash, que além de mais leve, projetava um feixe de luz com uma intensidade maior.

Professor Dante: Foi uma idéia muito boa, a confecção do equipamento e a utilização foi muito feliz, foi muito bem controlada, e agilizou muito as medidas. Eu não saberia como fazer se não fosse esse método. Era um retrato do túnel.

Este trabalho teve alguma influência posterior em sua carreira?

Professor Dante: Nessa época, um trabalho desse porte foi único. Desenvolvemos outros trabalhos, mas não com essa envergadura. Eu acredito que talvez, não no nível do consciente, mas no do inconsciente, essa atividade, principalmente pelo tamanho, essa ligação entre teoria e prática, e a parte de equipe, isso deve ter influenciado na minha decisão de continuar fazendo parte dessa equipe. Fizemos um outro trabalho para a COMASP, era um ensaio sobre uma válvula de dissipação de energia, que tinha ligação com esse trabalho, já no laboratório de hidráulica, nós já estávamos juntos na Hidráulica. Então foi um segundo trabalho grande, esse estudo sobre a dissipação de energia nas válvulas. Foi feito um modelo reduzido se eu não me engano. Este foi um outro trabalho bonito de modelação, de modelo. Nessa época, na Hidráulica, tinha poucos professores em 
tempo integral. Na Física Técnica, eu acho, todos eram em tempo integral. Na Hidráulica tinha muitos professores que eram parcial, porque eles vinham de São Paulo, eram profissionais muito competentes, com muita experiência profissional e vinham de São Paulo para ministrar as aulas aqui. Então o trabalho de laboratório era do pessoal de dedicação exclusiva que era o pessoal oriundo da Física Técnica. Que mais que podemos lembrar daquela época. Acho que se você me "refrescasse" a memória, podemos lembrar.

Depois dos ensaios com ar no túnel, como foi trabalhar com os dados? Como foi fazer as inferências para a vazão de água?

Professor Dante: Acho que pelo fato de ser o mais novo da equipe, eu me lembro que eu acompanhava esse trabalho de cálculo; se não me falha a memória, esse trabalho ficou a cargo do Prof. Ruy Vieira e do Hans; na minha visão, o Hans era o braço direito do Prof. Ruy Vieira; então eu acho, acredito que em uma certa altura do campeonato, o professor Ruy errou em uns cálculos e o resultado ficou desfavorável, ai o professor Hans fez uma revisão dos cálculos e falou: "não, há um lapso aqui"; aí ele corrigiu e nós chegamos a conclusão que dava para fechar, e foi a conclusão que nós deixamos no relatório. Isso ai é o que a minha memória diz, não sei. Era muito difícil fazer os cálculos naquela época, não dispúnhamos de calculadoras como hoje. Tínhamos uma calculadora muito rudimentar e ela era disputadíssima, ela era "top de linha". Eu acredito que eles passaram uns bons meses fazendo os cálculos para ver o que poderia tirar de conclusão lá. Eu fui em um congresso em Recife, em que fomos apresentar 
alguns trabalhos dessa consultoria, desse trabalho técnico prestado por esse departamento. Nós fomos, eu fui; acho que do Departamento eu fui o único a ir nesse congresso, em 1969, se eu não me engano. Foi uma equipe da COMASP, e eu fui representar esse trabalho relativo ao diafragma. Tinha vários trabalhos dos engenheiros da COMASP e eu fui com eles ao congresso. Agora um fato interessante, é muito interessante, é o seguinte, que além do produto técnico que causou uma economia muito grande para a companhia que nos contratou, outro aspecto foi que desse trabalho surgiram os prédios do departamento de Hidráulica atual, se não me falha a memória, nós, os docentes que trabalhamos, os técnicos, não recebemos nenhuma quantia significativa, não me lembro que mudou minha vida, mas deve ter entrado um dinheiro grande e isso foi investido no Departamento, isso aí, hoje em dia é uma exceção, naquele tempo me parece, ao menos pelo professor Ruy, foi uma regra. Os honorários foram todos doados para o Departamento e utilizados em construção civil. Eu não sei se era uma prática comum, isso foi uma decisão do Prof. Ruy Vieira, investir isso aí na própria unidade. Os laboratórios era na época do barracão. Nós trabalhávamos num barracão de madeira, a Física Técnica trabalhava inteira lá. Bem basicamente seria isso.

Hoje, o Sr. saberia, teria outra forma, de como fazer esse trabalho?

Professor Dante: Não, eu não pensei nisso não, mas provavelmente essa técnica da semelhança física continuaria sendo a opção, porque a potência envolvida, e porque como que iria fazer para circular a água se não tem a água... está tudo em construção... a obra não está pronta, não dispõe de água, só de ar... 
O senhor se lembra de algum problema durante os ensaios? Ventiladores, medições...

Professor Dante: Me lembro que eram três ventiladores, foi feita uma estrutura para dispor de uma maneira simétrica e eu não me lembro de ter havido algum problema não.

Os ventiladores, para o primeiro ensaio, não forneceram a vazão que havia sido projetada, eles não respondiam às curvas fornecidas pelos fabricantes, e vocês tiveram de trabalhar com uma vazão muito mais baixa do que a projetada para o ensaio.

Professor Dante: Agora eu me lembro... nós nos assustamos mesmo, a diferença foi muito grande, fomos pegos de surpresa. As velocidades eram medidas com Pitot, e eram velocidade baixas, o desnível no Pitot era pequeno. Tinha um problema sério, era o fato de que era com ar, e tinha problema de compressibilidade, não sei como é que foi levado em conta isso aí, mas eu lembro que nos deixou preocupados com o efeito de compressibilidade do ar dentro da mangueira, que tinha quilômetros de extensão, quilômetros de mangueira plástica transparente, me parece que pelo menos houve uma preocupação com a compressibilidade do ar na mangueira, mas como foi a muito tempo atrás, não me lembro mais. Acho que esse problema foi analisado e chegou-se a conclusão que não era relevante, mas houve um momento que nos preocupamos com esse problema. Bem, acho que é isso que eu me lembro, Hemerson. 
Muito bem, professor. Muito obrigado pela atenção.

Professor Dante: Ótimo, espero que minha colaboração tenha ajudado.

Com certeza, mais uma vez, muito obrigado. 


\section{A.3 Entrevista com o Professor Antonio Marozzi}

\section{Righetto}

Professor Righetto: Por onde vamos começar, Hemerson?

O senhor poderia iniciar falando sobre o início de sua carreira na EESC, que provavelmente coincidiu com o as consultorias que a escola prestou à COMASP.

Professor Righetto: Eu me formei em 1968 e no início de 1969 fui à São Paulo onde trabalhei na FESB - havia uma divisão entre COMASP e FESB hoje a SABESP - a FESB cuidava do saneamento do interior do Estado de São Paulo e a COMASP em São Paulo, ai trabalhei lá, na Planidro um pouco e junho/julho fui convidado para assumir o cargo de instrutor no Departamento de Hidráulica, o Swami quem me convidou, e na verdade eu comecei a dar aula em junho de 1969, não sei se contratado, acho que fui contratado em setembro de 1969, e nesse ano houve uma aproximação dos Departamentos de Física Técnica e Hidráulica, mas ainda trabalhavam separadamente. Eu acredito que esse trabalho de consultoria de 1969 foi feito só pela Física Técnica, a Hidráulica não participou, então eu não sabia direito o que estava sendo feito lá. Eu já tinha uma ligação com o Ruy Vieira, com o Marcius - não, o Marcius estava no exterior - com o Ruy Vieira, com o Hans, mas era um contato assim, mais de colegas entre departamentos, aí em 1970 foi que houve a junção dos departamento eu acho ou no final de 1969 foi criada a pós-graduação, e aí sim nós começamos a trabalhar juntos. Existia um 
modelo reduzido lá do desemboque do túnel, que era aqui no departamento, aqui no laboratório de hidráulica. Eu participei um pouco dos ensaios das válvulas, verificação da circulação de água e tudo mais. E aí, a partir de 70 eu comecei a me envolver nessa consultoria. Foi a primeira consultoria do departamento, já Departamento de Hidráulica e Saneamento, formado pela fusão da Física Técnica e Hidráulica, e a grande atividade, fora a atividade de graduação, era essa consultoria. A maior atividade do departamento, fora a graduação, era essa consultoria, onde se levantou muitos recursos, nós construímos esse prédio aqui, a atual administração e houve uma integração entre colegas e o maior benefício trazido por essa consultoria, eu diria, foi essa integração. Os dois departamentos com pessoas diferentes, uma linha mecânica, outra uma linha civil, então com esse trabalho em comum nós fizemos ótimos colegas, adquirimos uma intimidade, nós viajamos juntos à São Paulo, dormíamos por lá no acampamento lá do Sistema Cantareira. Foi muito divertido, pessoas muito diferentes. O Ruy Vieira era uma pessoas muito religiosa, vegetariano, muito sistemático; e aí nós tínhamos o Reynaldo Gava que era uma pessoa informal, bagunceira e a gente convivia nessa diversidade de personalidades mas de uma maneira muito amigável, muito boa, nos uniu muito. A gente iniciou a vida departamental com outra amizade; claro que havia indiferenças: de personalidades, de gosto. Nós formamos um time de futebol, começamos a jogar muito futebol de salão. O nosso departamento era um dos departamentos fortes no futebol de salão - isso com professores - um time muito bom. Então nossa amizade trouxe como benefício um bom início do departamento, do mestrado. A única crítica que eu faria àquela época lá, a gente 
tinha um respeito muito grande ao Prof. Ruy Vieira, e mas como ele era de uma linha muito de mecânica dos fluidos, muito mecânica, a gente tinha muita dificuldade de abertura de idéias para pesquisa. Ele nos amedrontava um pouco em torno de pesquisa, a gente não tinha muita abertura de cabeça "para poder fazer tal coisa para ver como que é; isso é uma pesquisa que eu vou publicar". Parecia que tudo era muito difícil, quer dizer, tem que ser muito inteligente para fazer alguma coisa nova para merecer uma publicação. Isso eu acho que atrapalhou um pouco o começo da vida do departamento em termos de liberdade de ação por parte de cada colega. A gente ficou assim muito indefeso e muito inseguro em relação a isso. E também o Ruy Vieira foi mudando. Ele desistiu da mecânica dos fluidos praticamente e entrou em águas subterrâneas, ele começou a gostar muito dessa área, pois ele via nisso o aspecto ambiental e houve a transformação do Prof. Ruy Vieira nessa época; uma pessoa assim muito rígida, ele foi também em função dessa vida nossa com a civil, principalmente com o Swami, uma pessoa muito aberta muito amiga, ele foi também se desfazendo daquela rigidez. Depois o professor Ruy nunca foi assim, pelo menos na vivência que eu tive, assim ele nunca teve um envolvimento na pesquisa assim de dedicação; quando eu conheci o professor Ruy ele já iniciou uma vida administrativa. Ele foi muito importante para o Departamento porque ele corria atrás, mas a atenção dele era toda voltada ao crescimento do Departamento através da administração, através das consultorias com a COMASP. Então foi assim o início da nossa, dessa junção departamental e o início da nossa pesquisa. Ai com o Mestrado, eu fiz o mestrado - fui uns dos primeiros a fazer o mestrado - acho que o primeiro foi Arthur Mar- 
ques, mas eu fui um dos primeiros. A gente também se envolvia em alguma coisa assim que a gente entendia que era importante para o aprendizado, então eu descobri o método numérico logo no meu mestrado em 70 e nunca mais parei e foi uma motivação pessoal, não foi assim uma aquisição de algum professor nada, eu gostava muito do método numérico já na graduação; na época, a gente usava uma maquininha de calcular tudo, maquininha mecânica de cálculo e já gostava da técnica numérica; daí para frente a minha vida profissional foi, acadêmica e profissional, sempre foi modelagem matemática e sempre na busca de algoritmos, técnicas numéricas para resolver problemas reais, problemas da engenharia. Então esse foi o início. E com relação a COMASP? Você pode me ajudar a me lembrar?

Sim. Vou falar, resumidamente, sobre os ensaios. Túnel 2 do Sistema Cantareira foi projetado e executado para uma vazão de $22 \mathrm{~m}^{3} / \mathrm{s}$. Depois houve uma mudança no projeto da ETA, que passaria a tratar $33 \mathrm{~m}^{3} / \mathrm{s}$. Resolveram assim realizar o rebaixamento do piso em toda a extensão da galeria. Iniciaram esse rebaixamento em duas frentes de trabalho, uma de montante para jusante e a outra de jusante para montante. Em determinado momento, passaram a questionar se haveria a necessidade de rebaixar o piso do túnel em toda a sua extensão e ainda, se a altura do rebaixamento seria suficiente para a nova vazão. Nesse impasse é que a então Cátedra de Mecânica dos Fluidos foi contratada para verificar qual era a vazão que o túnel seria capaz de aduzir naquela situação em que se encontravam as obras e, se necessário, quanto mais deveria ser rebaixado. Dependendo do parecer de vocês, continuariam ou não as obras de rebaixamento. 
Como foi para o senhor, que estava em início de carreira, participar dessa equipe, desses ensaios?

Professor Righetto: Com relação ao trabalho técnico da COMASP, eu tive uma participação no ensaio propriamente do túnel e também do estudo do modelo reduzido que foi feito aqui sobre a... porque tinha um diafragma na chaminé de equilíbrio e eles queriam determinar o coeficiente de perda de carga. Então eu participei, eu fui o coordenador desse projetinho, de um modelo reduzido, e a gente ensaiou aqui no laboratório com alunos de graduação, e ai fizemos o modelo numérico tal, de oscilação e determinamos o coeficiente de perda de carga. Com relação à COMASP e ao ensaio do túnel, houveram divergências nos resultados, eu acho que uma das coisas que me pareceu não ter sido bem previsto é, foram as medidas de pressão ao longo do túnel, porque a técnica foi colocar piezômetros, mas com ligação de quase quilômetros, até mais de quilômetros, entre o Pitot, por exemplo, e o manômetro que estava na entrada e na saída do túnel. E então nós ligávamos os ventiladores para determinada descarga e esperávamos um bom tempo para a estabilidade tudo, mas a resposta do manômetro era muito estranha, havia mudanças, variações que não eram muito bem explicáveis e eu pelo menos entendia que a resposta deveria ser rápida porque era uma onda de pressão. $\mathrm{Na}$ verdade não era uma onda de pressão, era onda de massa, era movimentação de massa. E a movimentação de massa num tubo pequenino de quilômetros demora muito tempo, então essa... houveram divergências e uma certa incongruência de resultados e tal, por isso que eu disse, não foi bem avaliado esse tempo de resposta, coisa de quarenta minutos. Em quarenta minutos havia também variação 
de pressão atmosférica dentro do túnel, fora do túnel e tal. Então haviam oscilações que precisariam ser bem interpretadas, isso depois, na análise. Eu não participei muito das análises, acho que foram o Ruy, o Hans e o Marcius, e com certeza foi levado em conta esse aspecto. No ensaio que nós imaginávamos que era uma coisa tranqüila, quer dizer, a dificuldade estava em montar o diafragma, montar os Pitot, jogar toda aquela tubulação dentro do túnel e tal; foi um trabalho maluco; eu participei; eu e Geraldo Lombardi atravessamos todo o túnel e levando essas mangueirinhas e lugares assim, cheios de água, difícil acesso, mas foi uma aventura, com radinho e tal, foi muito interessante, foi ótimo. Agora o ensaio que a gente esperava assim, ser totalmente bem sucedido, ter lá vazão contra diferença de pressão e com isso ter o conhecimento de rugosidade do túnel não foi uma tarefa fácil pelas dificuldades encontradas. Então foi a grande lição eu acho, de pesquisa para gente, que mesmo uma coisa que aparentemente tranqüilo de se fazer, na verdade... surgem novidades que levam a gente a ter que investigar. Então foi uma consultoria que levou as pessoas a pensar melhor nesse tipo de problema. Uma coisa é você fazer uma medição com uma tubulação curta, outra coisa e usar essas mangueiras de quilômetros. Hoje em dia não existiria mais isso, é tudo eletrônico e tal, não teria problema nenhum.

Talvez um dos problemas com o tempo de resposta foi devido aos ventiladores não terem fornecido a vazão projetada para o ensaio. O senhor se lembra desse fato?

Professor Righetto: Não me lembro muito, não. Me lembro que até que 
foi eu quem traçou as curvas características dos ventiladores, coisa e tal. Mas a análise de resultado ficou mais por conta de Hans, Ruy Vieira e Marcius, então eu não participei muito disso. Eu participei mais do ensaio de campo.

Sobre o Método Óptico.

Professor Righetto: O Método Óptico foi uma idéia do Hans de levantar a seção do túnel através, junto com o Paulo Pires - o Paulo era o fotógrafo - eles tiveram uma idéia de através de um sistema fotográfico, eles conseguiam ter a fotografia do perfil do túnel, com uma boa precisão. E dai, através de uma questão de distancia focal, eu até participei de medições com o teodolito, onde a gente fazia a conferência da medida da seção feita com o teodolito e a feita fotograficamente para ver a precisão. A precisão foi excelente, a precisão foi de 1\%, a gente nem sabia qual era a medida padrão: se era a fotográfica ou se era a feita com o teodolito, então eu participei, mas isso era uma pesquisa do Hans, isso resultou acho que no doutorado dele ou mestrado, acho que doutorado do Hans, que ele trabalhou com isso, ou publicação, não sei. Do ensaio do ventilador propriamente dito eu não participei. Participei do ensaio do túnel. Participei do ensaio de desemboque aqui, em modelo reduzido e trabalhei na chaminé de equilíbrio, que já é outro aspecto e também eu e o Gava demos consultoria na parte de transitório hidráulico no Sistema Cantareira, de avaliação do golpe de aríete, mas isso eram consultorias mais isoladas, não foi propriamente a consultoria do túnel, foi mais ou menos isso que eu participei. 
O Sr. citou Reynaldo Gava, ele era professor aqui no Departamento.

Professor Righetto: Ele foi professor. Ficou aqui, ele se aposentou aqui, já fazem acho que uns dez anos mais ou menos. O Gava ele era o... porque o Ruy Vieira ele era um catedrático de mecânica dos fluidos, ele tinha conhecimento básico de mecânica dos fluidos muito grande. O Ruy Vieira era o grande mestre, e o Ruy Vieira desenvolveu a carreira dele, também, com máquinas hidráulicas, e o Gava foi o assistente dele em máquinas hidráulicas, e dali para frente toda a vida do Gava foi de máquinas hidráulicas, então, portanto, ele deve ter trabalhado no ensaio dos ventiladores, tudo mais. Se tornou um especialista em máquinas hidráulicas e já assim, com dez anos para se aposentar, ele já era sócio de uma fábrica de bombas de Piracicaba. Ele se aposentou e assumiu essa fábrica de bombas. É chamada de Bombas Equipe, até hoje ele está nessa fábrica. O Gava é uma pessoa interessante, ele era diferente dos demais, porque a maioria de nós, tirando o Swami assim, porque ele já era uma pessoa mais independente, já conversava com o Ruy Vieira como amigo mesmo, colega, chamando-o de você, os demais era tudo "Senhor", o Ruy Vieira era muito formal. Até hoje, se o Ruy Vieira aparecer aqui eu não consigo falar com ele "você". É "Senhor". Nós éramos muito formais com ele e o Gava não, o Gava, apesar de chamar ele de senhor, era despachado, brincalhão e foi uma pessoa muito interessante no departamento, ele era muito diferente de todos nós. Nós éramos muito acadêmicos, ele não, ele era meio "relaxadão" do tipo técnico, mas muito capaz, ele era muito bom. Acho que você não ouviu falar muito do Gava, não? 
Não, não tinha. O Dante me falou um pouco dele. Os relatórios que eu consultei sobre os ensaios, os textos, estão todos impessoais, não denominam quem realizou, especificamente, as atividades relatadas.

Professor Righetto: Foi uma grande experiência para início do Departamento, ai com a abertura do mestrado, aos poucos nós fomos adquirindo independência e confiança e aí chegou um determinado momento que cada um começou a produzir e tal e aí aquela, aquele vínculo com Ruy Vieira foi desaparecendo, e cada um foi assumindo a sua parte. Eu por exemplo, fui uma das pessoas que caminhei... Eu sou uma das pessoas que assim, mais se envolveu em várias áreas. Eu sou uma pessoa de mecânica dos fluidos, sou uma pessoa de hidráulica, sou uma pessoa de hidrologia e de recursos hídricos. Eu transitei em todas essas áreas. Eu sempre fui assim. Sempre fui assim. Sempre trabalhei em todas essas áreas, gosto muito, porque a minha área é modelagem matemática, então não tem essa de hidrologia ou hidráulica. Se um problema exige aplicar uma técnica estocástica, eu vou utilizar a técnica estocástica. Se o problema exige que eu use o método deterministico de elementos finitos, eu vou usar elementos finitos, então eu trabalhei sempre nessas interfaces e fui uma das poucas pessoas que fez isso. A maioria que era mecânica ficou em mecânica dos fluidos e no máximo chegaram até em hidráulica. O pessoal que era de hidráulica e saneamento ficava ou em hidrologia ou hidráulica. Tirando o pessoal de sanitária, o pessoal de sanitária já era uma outra área, outro ramo. Mas os hidráulicos ficavam ou em hidrologia ou hidráulica. Eu que foi uma das poucas pessoas que me envolvi em todas as áreas; então eu tinha um trânsito muito grande tanto com o pessoal da 
mecânica dos fluidos quanto com o pessoal da hidrologia e tal, uma característica minha, eu sempre fui assim. Eu trabalho alguns anos, ai paro, vou trabalhar em outras áreas. Com a vinda do Fazal, o Fazal também é assim, o Fazal trabalhou muito com mecânica dos fluidos, lá onde ele ficou, oito anos nos Estados Unidos, ele era assistente em mecânica dos fluidos e ambiental e depois veio para cá e trabalhou na hidráulica, na hidrologia, em recursos hídricos. Então, eu e o Fazal somos assim mais "ecléticos" em termos de área. Os demais são um pouco mais especializados, por exemplo o Rodrigo, é mais em hidrologia e hidráulica e um pouco em mecânica dos fluidos. Mas o Rodrigo ficou mais na área didática, a pesquisa mesmo mais em hidrologia e hidráulica. Marcius. Marcius em fenômenos de transportes e mecânica dos fluidos... fica mais ali. Mas essa interface vai acontecendo, naturalmente, porque a nossa área é uma área abrangente.

Na entrevista com o professor Dante, ele me falou sobre a grandiosidade do trabalho, sobre a grandeza do túnel e a responsabilidade que teria o departamento nas inferências que este faria sobre as obras do túnel. Ele chegou a mencionar um certo "medo" relacionado a esse trabalho, até mesmo risco de morte, pois em certos pontos o nível da água chegava na cintura do pessoal que estava trabalhando no ensaio. O que o senhor diz a respeito desse ponto de vista.

Professor Righetto: Eu acho que existia uma certa euforia por parte da equipe por estar participando de um projeto técnico, técnico-científico dentro de uma obra muito importante para o Estado de São Paulo, que era o Sistema Cantareira, eu acho que existia sim muito orgulho, de estar participando de um 
projeto assim desse tipo. Esse "amedrontamento" acho que não tive, não. Foi muito divertido na verdade, foi muito divertido. Íamos para são Paulo, saíamos de madrugada. O Geraldo Lombardi era uma pessoa muito, muito boa pessoa, mas ele tinha umas manias. Ele não admitia por exemplo: vamos sair às 5 horas e chegar na casa de alguém e a pessoa estava dormindo ainda. Estragava o dia dele, ficava emburrado. Ele não admitia que uma pessoa pudesse cometer um desvio desses. Isso faz parte da vida, os demais não ligavam. Tudo bem, vamos esperar 15 ou 20 minutos até a pessoa se aprontar e depois ir embora. Então era engraçado, porque as pessoas eram muito diferentes, mas nem por isso, gerou inimizades não, a gente fez grandes amizades. Eu me lembro que na época também fomos fazer as medidas lá até de madrugada e tal e o Ruy Vieira chegou lá e viu aquelas medidas que estávamos fazendo e fez um comentário, assim, meio maldoso; eu e o Gava ficamos muito sentidos com o Ruy Vieira, inclusive ficamos assim um dia ou dois melindrados, porque ele foi muito injusto, e era motivo desse comentário que eu fiz sobre a medida, ou seja, não éramos nós que estávamos medindo errado, era o projeto de medição que foi mal feito, quer dizer, não avaliaram uma coisa que era importante de ser avaliada. Então aconteceram essas coisas tal, mas tudo isso passou e não deixou marcas nenhuma, não. Então eu acho que a lição que fica também, já desde aquela época, é quando você trabalha em equipe não deve haver uma preocupação tão grande de que não haja discussão, que não haja brigas, que não haja... isso faz parte da vida, acho que as pessoas tem que ser sinceras, verdadeiras e se você discute, depois passa, porque não há maldade. Não houve maldade, foram relações normais de trabalho. Então trabal- 
har em equipe significa isso, acho que tem de ser verdadeiro, colocar para fora o que pensa e tocar a bola para frente. Eu acho que o sucesso do Departamento foi esse. O Departamento cresceu muito, no começo às nossas custas, porque a Universidade não dava nenhum recurso a não ser o nosso salário e até hoje você vê aí que a maior parte dos diretores da Escola são do Departamento de Hidráulica e Saneamento. Por quê? Porque é um Departamento que conseguiu construir liderança e tudo mais; então acho que isso foi um sucesso, a Hidráulica foi um sucesso. Começou bem, foi construída bem. Então eu acho que a experiência lá do ensaio do Sistema Cantareira foi muito positiva, eu acho que não houve um... para mim eu acho que houve uma decepção quando vi aqueles resultados. Eu esperava uma coisa tranqüila; medir lá a vazão de o $\Delta P$ e jogar lá na curva e seguir mais ou menos aquela curva de Nikuradse, e isso não ocorreu bem porque teve de haver uma interpretação. Na época a gente não tinha outra alternativa. Como é que você ia medir pressão? A não ser que ficasse lá dentro do túnel. Talvez a idéia melhor fosse essa: alguém ficar plantado lá, fazer o ensaio e alguém medir ali e não levar essa, esse sinal lá pro desemboque. Eu acho que hoje eu teria feito isso. Ma foi muito bom. Foi isso aí.

Muito obrigado Professor, desculpe-me por ter tomado esse tempo do senhor, eu sei que o senhor está indo para São Paulo agora cedo. Muito obrigado mesmo.

Professor Righetto: Não, não se preocupe. Estou indo para são Paulo com bastante folga. Ok, foi ótimo. 


\section{A.4 Entrevista com o Professor Ruy Vieira}

Professor Ruy Vieira, pela documentação consultada acerca dos ensaios do Túnel 2 e pelo depoimentos de seus colegas, o senhor foi o coordenador desse trabalho. Então gostaríamos de registrar em nosso trabalho de mestrado o seu depoimento. Para tanto, se possível, o Sr. poderia relatar como foi que a Escola de Engenharia, a EESC, entrou nesse trabalho?

Professor Ruy Vieira: Tem uma parte muito interessante que não está escrita em lugar nenhum, e que talvez só eu e nossos colegas como o Marcius, etc., tenham lembrança disso, talvez até conhecimento. Dos meus velhos tempos de aluno na escola Politécnica, eu era de uma turma de mecânico eletricistas e tinha certas amizades com a turma de civil; e havia um aluno na civil que era o Tufi Mamed Assy, que era do Amazonas, ele tinha passado no vestibular na Politécnica de São Paulo como eu também, e por várias circunstâncias nós ficamos amigos, no sentido de apreciarmos música clássica, com a possibilidade de assistirmos alguns recitais, etc...Então fizemos uma certa amizade. Depois que nós nos formamos, nem sei para onde ele foi, eu sei que eu fui para São José dos Campos e depois para São Carlos. Sou são carlense e minha familia é de lá, eu tinha interesse em estar lá naquele começo, formar uma escola de engenharia por lá. E o tempo passou, eu fiz a minha carreira na Escola de Engenharia de São Carlos da Universidade de São Paulo. Fui para essa área mecânica dos fluidos quando eu fui para o ITA. Já era a minha intenção aprender mecânica dos fluidoslá, porque naquela época no Brasil não tinha nada de mecânica dos fluidos. Muito bem, são coisas que a gente precisa mencionar, pois sem isso fica 
meio difícil de entender como é que a COMASP entrou no meio de tudo isso. E eu era já catedrático por concurso na Escola de Engenharia de São Carlos, e o Tufi já estava na Politécnica como professor também na área da engenharia civil ligada ao Departamento de Hidráulica, e interessado em mecânica dos fluidos. Eu não sei muito bem como nós nos encontramos nas vésperas da prova do concurso dele de livre docência, e eu o ajudei no preparo da aula e em umas outras coisas. Eram várias provas, eu não sei se ainda hoje são várias provas. Tinha prova escrita, prova didática, uma prova oral sobre determinado tema e assim por diante, além da tese propriamente dita. E isso foi elevando um pouco mais a nossa amizade. O tempo passou um pouco mais e o Tufi fez carreira, até oconcurso para catedrático também. Essa parte eu não estou bem lembrado no momento. Mas o fato é que fundaram essa Companhia Metropolitana de Água no Estado de São Paulo, a COMASP, e o Tufi ficou como assessor do presidente dessa companhia, não sei bem porquê, se tinha alguma amizade com alguém. Ele era professor da Politécnica e encontrando-o meio casualmente, o Tufi, ele mesmo mostrou interesse que nós da mecânica de São Carlos participássemos do projeto da COMASP. Na ocasião estávamos na chefia do departamento, desde a reforma universitária, em que antes haviam as cátedras e elas foram abolidas; três cátedras foram juntadas, que eram a Cátedra de Hidráulica, a de Saneamento e a de Mecânica dos Fluidos e Termodinâmica Aplicada, que já tinha sido dividida em dois setores que eram: Mecânica dos Fluidos e Termodinâmica Aplicada. E eu optei (não era bem a cátedra), pelo setor de Mecânica dos Fluidos, que era o que eu sempre quis na vida. Dai foi formado o Departamento de Hidráulica e de Saneamento, 
que teve essa peculiaridade que além de ter hidráulica e saneamento, teve uma parte básica de mecânica dos fluidos, caso que foi o único no Brasil. Isso deu um grande impulso a toda hidráulica e saneamento porque deixaram todo aquele empirismo e entraram na parte mais básica e conceitual. Muito bem, então eu fiquei como chefe do departamento e tentando impulsionar o departamento para frente da melhor forma possivel. Dai aconteceu de ter contato com o Tufi, que me disse: "olha, nós queremos que você assessore isso aqui, ajude isso e aquilo..." e começou uma interação entre nós do departamento e a COMASP. Não sei se foi feito um documento básico citando a nossa cooperação porque todos nós éramos de tempo integral e precisávamos da autorização da EESC para fazer este tipo de serviço. Tinha que pegar a autorização formalmente ou através de um pedido formal. Então nós acionamos a comissão de tempo integral e ela acabou dando essa autorização para nós trabalharmos nesse projeto que tinha a ver com o túnel, que era uma obra de engenharia, muito grande. Eles já estavam construindo o túnel e havia um estudo feito pelos engenheiros de uma firma da Suécia que dizia que o túnel tinha que ser rebaixado mais não sei quantos metros, para poder dar vazão, com aquele desnivel aos $33 \mathrm{~m}^{3} / \mathrm{s}$. E para continuar escavando ia muito tempo, ia muito dinheiro, então decidimos fazer um ensaio do túnel e o Tufi foi quem acionou na COMASP essa questão de ensaio do túnel; levantou a questão de bibliografia e nos contatos que nós fizemos com o Tufi, ele passou para nós esse encargo, conversando com o presidente da COMASP, Haroldo Jezler. Então nós fizemos o convênio ou coisa semelhante e a partir disso fizemos um projeto do ensaio do túnel. E esse projeto foi meio complexo porque nós teríamos pouco 
tempo para fazer o ensaio do túnel porque não podiam parar as obras. Se tinha mesmo que ser rebaixado eles tinham que continuar rebaixando, e isso significava estar explodindo dinamite lá dentro do túnel durante os nossos ensaios. Isso tinha que parar, para o ensairo ser feito rapidamente em pouco tempo, em poucos dias. Então nós ficamos programando como seria o ensaio. A primeira parte foi a parte conceitual, fazer toda a análise dimensional e semelhança para poder saber o que a gente tinha que fazer, o que tinha que medir e o que essas medidas representariam nesse ensaio com escoamento de ar, quando o escoamento fosse de água. Bom, dai fizemos todo o projeto. Os projetos foram complexos porque, além de toda essa parte conceitual de dinâmica, etc... que envolvia coisas do tipo calcular a rugosidade média do túnel e que metodologia seria usada para isso. Ai foi desenvolvido com o Paulo Pires também, o sistema óptico de fotografar as seções do túnel. Não sei se você chegou a ter conhecimento, isso era uma parte que tinha a ver com esse projeto todo, do que nós iríamos fazer no todo. Tivemos de fazer um medidor de vazão, que seria um orifício circular e teríamos que calibrar o coeficiente de vazão desse medidor de vazão. Fizemos um modelo reduzido, com ar, com todo o projeto do ventilador que ia produzir o fluxo de ar necessário para gente ter a curva de calibração desse medidor com as condições de contorno correspondentes à entrada e saída do túnel. E daí tivemos de fazer um modelo em gesso do túnel da parte que estava revestida e com a inserção do bocal. Não era bem um bocal, mas um orifício, e teve que ser usinado em madeira. Só a usinagem desse orifício de madeira foi outro desafio, não havia máquinas para fazer a usinagem etc... das peças de madeira. E depois, como transportar isso. Foi 
uma coisa realmente grande, foi mesmo um desafio que conseguimos ir superando. Outro desafio foi a medida de pequenas diferenças de pressão do ar no túnel, e ai então foi desenvolvido um manômetro. Arranjamos um manômetro Betz, emprestado de Itajubá, porque nós não tínhamos. Estávamos tentando construir um manômetro parecido e tinha o manômetro inclinado que o Geraldo Lombardi tinha desenvolvido também e foi utilizado, se eu não me engano, um na entrada e outro na saída do túnel. Tivemos de fazer os tubos de Pitot para tomar as pressões dinâmicas e tivemos que ter os tubos de plástico conectando os tubos de Pitot aos manômetros dentro do túnel. Tudo isso foi programado. E quando nós fomos até comprar as mangueirinhas, eu me lembro muito bem, eu vim aqui a São Paulo numa firma, e estava conversando com eles; eles ficaram curiosos, porque quem iria comprar tanta mangueirinha plástica assim, "para medir a vazão do túnel que a COMASP está construindo aî". Aí eles disseram:"mas toda a água de São Paulo vai passar por esses tubinhos?". Isso foi muito interessante também. Bom, estou meio que andando para lá e para cá, mas pode me segurar para irmos para algo mais objetivo.

Pelo que eu pude observar até agora o senhor falou basicamente do primeiro ensaio...

Professor Ruy Vieira: Não foi um ensaio só?

Foram dois ensaios.

Professor Ruy Vieira: Não. Nesse túnel foi um ensaio só. Uma só vez, 
certeza absoluta. Nós estávamos dentro do túnel quando aquele primeiro astronauta americano chegou à lua. Estávamos lá embaixo do túnel, foi só essa vez, foi só esse ensaio.

Eu tenho dois relatórios de dois ensaios. Nesses relatórios, eles justificam o por que de terem realizados dois ensaios: O primeiro vocês fizeram para avaliar qual era a vazão que o túnel era capaz de aduzir, em 1969, naquelas condições em que as obras de rebaixamento se encontravam. O segundo foi realizado 1972 depois de ter terminado as escavações sugeridas no primeiro ensaio.

Professor Ruy Vieira: Ruy Vieira: Espere aí. Em 1969 que o homem foi para lua. E depois foi em... Nossa, eu estou tão desmemoriado!

O Professor Geraldo também teve essa dúvida.

Professor Ruy Vieira: Não, nós fomos uma só vez porque um super caminhão levou tudo. Tenho a fotografia do caminhão, em preto e branco, na frente daquele barracão na física técnica, onde nós ficávamos. Olha, certeza absoluta que foi um só. Porque em 1972 eu já não estava mais em São Carlos.

Tenho aqui os dois relatórios. O do primeiro ensaio e o do segundo...

Professor Ruy Vieira: Ah não, este é um relatório da COMASP não e nosso. 
Sim, esse é um relatório da COMASP, aqui está o outro

Professor Ruy Vieira: Ah não, nesse aí nós nã temos nem ciência disso... Em 1972...

Em 1972 foi feito outro ensaio; já com o túnel pronto, este segundo está bem mais documentado que o primeiro. Pelo filme dá para o senhor perceber a diferença...

Professor Ruy Vieira: Mas isso aqui é o próprio ensaio.

Tanto no filme do DVD quanto nessas fotos dos ventiladores utilizados nos dois ensaios, dá para perceber a diferença; no primeiro ensaio os ventiladores foram colocados fora do túnel, no desemboque, e no segundo ensaio, dentro.

Professor Ruy Vieira: Isso aqui é um ensaio.

Esse aqui é o de 1972. E esse aqui é o ensaio que vocês fizeram em 1969.

Professor Ruy Vieira: Mas isso aqui é do primeiro ensaio, isso foi medido. Quando é que foi posto de novo aquele ventilador no segundo túnel? Se colocasse um ventilador lá ia levar um tempo enorme, isso aqui é o primeiro ensaio. Tudo isso aqui é o primeiro ensaio.

Deixa-me ver se eu tenho uma foto aqui para diferenciar. 
Professor Ruy Vieira: Isto aqui é o primeiro ensaio. (leitura...) Olha, eu não estou sabendo disso, não.

No primeiro ensaio aconteceu o seguinte, os ventiladores vocês iam emprestar eles de uma empresa e não foi possível, daí os ventiladores quando foram entregues já direto na construção, direto no túnel, vocês não os ensaiaram. Assim, durante a realização do primeiro ensaio teve o problema que o ventilador não dava a vazão...

Professor Ruy Vieira: Esse é o primeiro relatório, primeiro ensaio... (leitura). Isso aqui não tem ensaio, isso aqui é data, não é possível... (leitura).

Professor Ruy Vieira: Olha, eu, o Geraldo, o Marcius... O Marcius sabe que foi dois ensaios? Foi um ensaio simplesmente.

Professor Ruy Vieira: Olha em $19^{72}$ eu estava...

Olha só a pequena diferença do ventilador...O primeiro tinha quatro hélices e o segundo tem mais; no primeiro ensaio, os ventiladores foram instalados do lado de fora. Pelo filme a gente vê que nesse outro ensaio eles foram colocados um pouco dentro, o túnel que já estava mais acabado...

Professor Ruy Vieira: Olha, eu desconheço esse ensaio, deixa-me fazer uma... Bom acontece o seguinte, eu estou lembrado que em 1972, com esse cronograma ai... Foi quando eu deixei o departamento... 
Na documentação consultada o senhor assina vários documentos ainda. Olha, para o segundo ensaio em 1972, foram feitos os relatórios separados...

Professor Ruy Vieira: Deixa-me ver, os ventiladores...

Professor Ruy Vieira: Bom acontece o seguinte, preciso saber a data precisa em que eu deixei o departamento. Em 1972, a minha impressão é que eu não estava mais. Então nesse segundo ensaio eu não participei.

Professor Ruy Vieira: Bom, deve ter sido um pedido do Swami que eu tenha ajudado, mas acontece o seguinte: chegou um determinado momento na escola, que eu me desencantei com o Departamento, não vou comentar em detalhes porque isso é meio complexo. E é muito natural da minha personalidade, eu dou a vida para o negócio até determinado ponto em que eu me desencanto e dai eu me separo totalmente e acabou, eu não existo mais para aquele negócio! Então é por isso que eu não participei desse segundo ensaio. Estou vendo que você realmente tem razão, ele deve ter sido feito, mas se eu participei foi porque o Swami pediu, algum contato, mas eu não entrei no túnel eu não entrei na segunda vez, só na primeira vez. Só organizei aquela primeira expedição com aquele primeiro caminhão levando aquelas coisas todas onde foi usinado o diafragma, o bocal, e fiz aqueles contatos com o exército para solicitar o telefone, comprei as mangueirinhas, discuti as questões dos ventiladores, não me lembro mais como apareceram os primeiros ventiladores. Os ensaios desses ventiladores foram feitos. 
Então, foram feitos os ensaios dos ventiladores para o segundo ensaio. Esse aqui foi ensaiado (figura). Esse aqui teve um problema de que vocês iam pegar emprestado de uma empresa chamada Mareli e ia ser emprestado, só que na ocasião do ensaio, eles estavam sendo utilizados; como vocês já tinham feito todo o levantamento e a especificação no relatório sobre a justificativa para o primeiro ensaio, tinha sido feita uma cotação dos preços dos ventiladores; assim a COMASP adquiriu os três ventiladores, só que eles não foram ensaiados, eles já foram levados direto para o túnel. E apenas para o segundo é que os ventiladores foram ensaiados na escola.

Professor Ruy Vieira: É. Eu me lembro que eu participei do ensaio dos ventiladores, que seria do primeiro e não do segundo. O segundo eu não estou nem sabendo.

A curva não havia correspondido com a que o fabricante havia dado.

Professor Ruy Vieira: Isso, você tem razão.

Para o segundo ensaio...

Professor Ruy Vieira: Isso estou lembrado, acho que até foi o Dante que ajudou nesse ensaio. Construímos um túnel com cambotas de madeira, tinha a parte circular, tinha de seguir as normas...

Professor Ruy Vieira: Tem a data em que foi feito os ensaios? 
Não, nos relatórios não constam as datas das realizações das atividades, tenho apenas a data da entrega do relatório.

Professor Ruy Vieira: Eu me lembro da minha participação no ensaio desse túnel, desse ventilador.

Eu só tenho a data da entrega

Professor Ruy Vieira: Qual é a data?

23 de agosto de 1972.

Professor Ruy Vieira: Eu me lembro bem do meu desencanto, e que me desliguei dessas coisas com o desencanto. Por isso não fiquei sabendo do segundo ensaio. Foi aí que eu acabei entrando na Comissão de Especialista de Ensino de Engenharia do MEC. Ao invés de fazer coisas diplomáticas com a Escola, fiquei ligado fazendo contatos com as escolas de engenharia, trabalhando para o aprimoramento do ensino da engenharia; aí foi fundada a ABENGE, quando se fez um programa no MEC para avaliar as escolas, pela primeira vez. Em $19^{7} 6$ eu acabei mudando para Brasilia, porque eu estava na Comissão de Engenharia e acabei indo para o Conselho Federal de Engenharia. Eu mudei, foi uma mudança de rota total, pelo desencanto pelo departamento.

Todos que eu entrevistei, colocam a pessoa do senhor como o "grande coor- 
denador"; todos tinham pouca experiência, recém formados, acho que o Marcius já tinha o mestrado, o Dante ainda não; era uma equipe muito nova, totalmente inexperiente e eles colocam o senhor como um grande incentivador, então como que foi para o senhor formar essa equipe?

Professor Ruy Vieira: É o que eu estava lhe dizendo, vem do contato com o Tufi, que já apareceu por aí. Já até mencionou o nome do Haroldo Jezler e nosso contato com a COMASP, o convênio ou coisa semelhante; que já tinha até pegado uma autorização da Comissão de Tempo Integral da USP. Todo mundo trabalhava e recebia um adicional que incorporava os seus vencimentos, uma parcela dessa remuneração ficava para aprimorar o departamento. Aquele edifício Euclides da Cunha foi construído com dinheiro da COMASP; a compra de uma Kombi, de uma Veraneio, que ficaram servindo para gente ir e voltar, independente de ficar pedindo autorização da escola para pagamento de gasolina, a xerox que foi comprada (naquela época, xerox era uma dificuldade). Até a perfuradora de cartões, na época que tinha aquele computador IBM, e o grande gargalo era a perfuração de cartão. Tudo isso foi resultado desse trabalho na COMASP, que deu recurso para a gente aplicar. Agora, o incentivador se fui eu realmente, é porque eu tinha o ideal para fazer um departamento que fosse realmente um departamento diferente dos outros do Brasil, no qual a mecânica dos fluidos fosse a base tanto da hidráulica como do saneamento. E daí aceitar esse projeto e trabalhar no projeto aglutinando pessoal de mecânica dos fluido e de hidráulica, era muito produtivo. E, era a idéia principal, a de fazer um departamento realmente forte, que fosse reconhecido nacionalmente etc. Agora, depois 
do primeiro ensaio, que você está me convencendo que houve mais um...

Professor Ruy Vieira: Pois é, daí eu realmente me desliguei, eu não estava nem mais sabendo do segundo ensaio. Provavelmente é até um mecanismo psicológico. Bom, mas tudo foi originado... Mas qual era a sua pergunta mesmo?

Como foi montar a equipe, para esse trabalho de grande dimensão...

Professor Ruy Vieira: É verdade. De alto nível e de alto risco também. Mas eu acho que foi interessante. Foi um idealismo nosso que não teve continuidade. À parte desse idealismo vem outro idealismo que originou o Broa que também é outra coisa interessante.

Já que o senhor mencionou o Broa, eu encontrei um documento no qual o Sr. mostra a intenção de formar, junto com a COMASP, um Centro de Estudos de Mecânica dos Fluidos e Hidráulica, na Usina do Lobo.

Professor Ruy Vieira: Exatamente. Junto com a COMASP não. Mas isso aí é outro capitulo da história, que andava paralelo, por condições mais de coincidências gerais. Eu sempre quis ir para esse ramo de mecânica dos fluidos com alunos da escola, envolvendo turbinas hidráulicas especialmente, e a parte toda de usinas hidrelétricas. Eu me formei como mecânico eletricista, mas mais para mecânica e mecânica dos fluidos. E quando eu me formei e fui para o Ita, o Professor Peters, com quem eu trabalhei lá, que era alemão e estava sendo chefe 
do departamento de mecânica, conversando com ele, disse: "olha vamos conseguir uma usina hidrelétrica aqui perto para ser um laboratório nosso para ter uma escala maior". Eu gostei da idéia e fomos procurar. Tinha uma usina na serra perto de São José dos Campos e Caraguatatuba. Bem, eu deixei o Ita e fui para São Carlos com essa idéia, lá do Ita para fazer em São Carlos. Eu tinha sido estagiário do Departamento de Águas e Energia Elétrica em São Paulo. E fui o primeiro estagiário porque foi criado esse Departamento, no tempo do governo de Garcez, que também criou a Escola de Engenharia em São Carlos, no tempo em que eu estava ainda Ita. Quando eu estava no Departamento de Águas e Energia Elétrica, eu tive contato com o pessoal todo e especialmente com o Alberto Kuymidjan, que era um engenheiro recém formado. Eu era ainda estagiário e não tinha me formado, e ficamos muito amigos. O tempo passou, eu fui para São Carlos e ele saiu da sede em São Paulo, e foi para uma regional em Rio Claro. Vindo de São Carlos para São Paulo, uma das viagens que eram freqüentes, a gente parava no caminho para tomar um lanchezinho, na volta para São Carlos. Um dia me encontrei com o Alberto Kuymidjan e numa dessas paradas conversei com ele, e falando que eu estava procurando uma usina ele me disse que tinha a Usina do Lobo, "que está na minha regional e é um ótimo lugar para você fazer esse negócio". Dai fizemos todos os contatos iniciais com ele, o Garcez que então era Presidente da CESP, deu a autorização e saiu esse convênio nosso com a CESP para poder usar a usina do Lobo, Daí começou o embrião do que se tornou o CRHEA. Tudo foi também dentro daquela equipe que formou o departamento, mas a COMASP não tomou parte disso. 
Bom, sobre o método óptico, no qual o Sr. e o Hans enviaram trabalho para o Japão...

Professor Ruy Vieira: Exato, no Japão. Até pedimos auxílio para o CNPq e ele nos deu a passagem só de volta, porque tinha medo da evasão de cérebros do Brasil e então faziam de tudo para evitar gastar dinheiro. E acabei não indo para o Japão, nem o Hans nem eu, mas temos o trabalho que foi publicado no Congresso Internacional. Eu não consegui cópias de nada, mas a gente mandou e foi aceito, tanto que tenho cartas do CNPq.

Como surgiu o Método Óptico?

Professor Ruy Vieira: Bom, a idéia era o seguinte, o pessoal da COMASP tinha que fazer um cálculo da rugosidade do túnel para aplicar os princípios (que não eram esses da semelhaça) para fazer ensaio; então era muito legal, mas tinha um método muito vagabundinho para determinarem raio hidráulico, e daí entrar numa curva lá do coeficiente de atrito em função no número de Reynolds, com a rugosidade, e tinha que fazer um cálculo para ver se passava ou não passava a tal da água. Bem, eles mediam as seções do túnel com um transferidor e com uma fita métrica que saía da trena aqui e a ponta ia até o solo e com um caderninho marcando tantos graus e o comprimento. Os caras da Suécia faziam um negócio desse! Pensamos, "então vamos bolar um método", e como o Paulo estava circulando com uma idéia para lá e para cá, vamos fazer uma cortina de luz e fotografar essa cortina de luz e vamos ver as escalas e etc, e aí a gente 
tem o perfil rugoso de cada sessão. Então foi assim que surgiram as coisas, em diálogos e conversas. Pois é, e pelo método óptico você pode fazer uma análise imediata, fotográfica, mesmo naquela época não tinha computador para fazer qualquer análise, mas pelo menos você tinha elementos muito mais precisos qparavocê calcular o raio hidráulico.

Vocês tinham uma escala...

Professor Ruy Vieira: Exatamente. Nós chamávamos aquilo de forma de pizza, eram duas formas de pizza, um flash toroidal, e dai tinha duas hastes que davam a distância de um metro. Então quando saia a fotografia saia metro e escala.

Tem uma Carta do Professor Macagno sugerindo adaptações ao método...

Professor Ruy Vieira: Sim, um argentino. É, pode ser. O Paulo Pires descobriu onde tinha o flash. Tinha que procurar em São Paulo, e também a bateria para o flash, eu me lembro muito bem disso. A gente tinha um diálogo com o Macagno, que foi em 1971 em São Carlos, para fazer um estudo sobre o futuro do departamento. Há uma série de relatórios, e deve ter uma cópia lá. Ele tinha uma mentalidade bem avançada e sugeriu " faça a tal de engenharia ecológica", que hoje em dia é a nossa engenharia ambiental, que também abordava a questão ambiental. Nessas conversas com ele a gente foi incrementando aquilo que foi preciso ser incrementado. 
Tanto no primeiro como no segundo ensaio tinha o problema do entulho e o problema da água dentro do túnel, e o Sr. orientou a tese de doutorado do Hans...

Professor Ruy Vieira: Pois é, eu estava pensando no sistema das ondulações da água e etc...

É, o trabalho dele foi produzir um coeficiente de correção...

Professor Ruy Vieira: Isso. Que formavam as ondinhas que correspondiam a uma certa rugosidade também.

Diminuía o diâmetro hidráulico...

Professor Ruy Vieira: Isso. Exatamente. A minha impressão é a seguinte: nós estávamos unidos para fazer aquele primeiro ensaio, todo mundo reunido, vamos fazer mesmo o ensaio, resolver todos os problemas, nós temos capacidade para fazer, vamos tocar a coisa para frente. Uma coisa me desencantou e eu pulei para fora, e acho que desarticulou um pouco, tanto que as pessoas talvez nem se lembrem de algumas coisas porque nem participaram mais. O Sr. entrevistou o Swami? É uma pessoa importante, ele deve lembrar, é interessante entrevista-lo.

É, o que eu consegui acompanhar através dos relatórios, é que o primeiro foi muito rápido, vocês tiveram que ir atrás das bases teóricas, construir todos os 
equipamentos, adquirir mangueiras...

Professor Ruy Vieira: É. Fazer a coisa toda, foi uma engenharia de $\operatorname{produção.~}$

A curto prazo.

Professor Ruy Vieira: Para ir, para fazer e para voltar.

Além do ensaio do túnel não poderiam parar as aulas...

Professor Ruy Vieira: Perfeitamente.

O projeto para o segundo ensaio está muito mais estruturado nos relatórios, alguns erros do primeiro foram corrigidos, etc... Bom, as conclusões do primeiro, o túnel naquela situação que se encontrava, ele tinha sido já rebaixado um tanto; a empresa responsável sugeriu rebaixar a bancada do túnel em dois metros em toda a extensão...

Professor Ruy Vieira: Eu estou lembrado disso.

Haviam rebaixado 800 metros de um lado e 1800 do outro quando vocês fizeram o ensaio. E vocês concluíram que precisava continuar um pouco mais, o senhor está lembrado?

Professor Ruy Vieira: Sim. 
A conclusão do relatório foi que cerca de 2800 metros não precisavam ser rebaixados, ou seja, foi uma economia muito grande. Já no segundo ensaio, com as escavações finalizadas, a conclusão foi que naquela situação, mesmo com o problema do entulho, passariam $37 \mathrm{~m}^{3} / \mathrm{s}$..

Professor Ruy Vieira: Então, eu só queria saber se alguém mediu o que está passando.

Não tenho registro disso, apenas as medíções feitas pelo Consórcio Intermunicipal das Bacias dos Rios Piracicaba, Capivari e Jundiaí, que acompanham a vazão do sistema, publicam em seu relatório mensal, uma vazão de 31 a $33 \mathrm{~m}^{3} / \mathrm{s}$. O Sr. se lembra de alguma dificuldade que vocês tiveram?

Professor Ruy Vieira: Na verdade isso é geral, você montar um negócio em pouco tempo com toda conceituação. Mas o que realmente nos ajudou foi o sistema da mecânica dos fluidos. Se fosse um hidráulico formado pela politécnica não ia fazer isso. (Afinal, podia até fazer.)

Olha, aqui no cronograma, aparece o nome do senhor em uma das equipes do segundo ensaio...

Professor Ruy Vieira: Como eu não me lembro, eu devia estar apoiando a parte de transporte. Mas esse segundo, foi com a organização ou com o relatório que a equipe trabalhou desse jeito? 
Foi realizado um novo ensaio.

Professor Ruy Vieira: Porque de repente... Mas me diz uma coisa...

$\mathrm{Eu}$ acho que o senhor aparece no filme...

Professor Ruy Vieira: Eu acho que eu não estou nem sabendo que foi filmado o segundo ensaio, para mim só tinha sido filmado o primeiro com aquela história do filme que foi revelado como sendo branco e preto e era colorido... Bom, não era nada, não...

Então acho que podemos encerrar nossa entrevista. Muito obrigado pela colaboração... e não atrapalhei sua viagem?

Professor Ruy Vieira: Não. Nossa entrevista é amanhã. É, eu ia para Brasilia se eu não estivesse em São Carlos... Você não tem que agradecer nada... 


\section{A.5 Entrevista com o Professor Geraldo Lombardi}

Gostaria que o Sr. me falasse sobre a consultoria que a Escola prestou para a COMASP, em 1969 e 1972 nas obras do Sistema Cantareira, a consultoria do Túnel 2 desse sistema.

Professor Geraldo Lombardi: Nós íamos medir a perda de carga, e quem fez todo esse projeto foi o Professor Marcius, talvez o professor Ruy Vieira que fez o projeto, talvez tenha ajudado a ele o Professor Marcius, que é da faculdade. Então chegando lá nos alojamentos, o túnel escavado na terra, as pedras ... com água no piso em determinados lugares. E a gente escutava, de vez em quando, cair uma pedra. E a gente escutava aquilo, mas não tinha muita consciência do problema. E também era um túnel enorme, parece que tinha uns 3 quilômetros...

4.826 metros.

Professor Geraldo Lombardi: Isso mesmo. A gente tinha que andar com chapéu, mas na verdade ninguém anda de chapéu. Quem andava de chapéu era o governador... a gente anda é de capacete. O nosso meio era confortável, a alimentação... pelo menos naquela época eu não tinha muita restrição. Ficávamos ali nos divertindo com toda aquela trabalheira, aquelas medidas... E eu me lembro que a gente tinha que passar as tubulações para medir as pressões; os equipamentos foram todos feitos aqui no laboratório. Nós tínhamos funcionários muito bons lá, o Recchia, o Pico, isso naquela época. Então, era uma equipe 
muito boa. Você sabe, o Pitot é um manômetro diferencial e se o regime for plenamente eu não tenho escoamento dentro da tubulação, eu não tenho perda de carga. Então, aquilo que eu leio corresponde à questão dinâmica, à questão da energia, da variação da quantidade de energia, que é a força necessária para parar o escoamento, que é aquela diferença de pressão. Então nós fizemos essa instalação, de quatro quilômetros... Será que era a estática ou a dinâmica? Eu tinha a dinâmica, mas eu não sei se tinha também que medir a pressão estática, porque já dá diferente e se você quiser medir a estática, tem que fazer outro ramo e ter essa terceira coluna. Eu não sei se a gente tinha essa terceira coluna, mas eu falo para você um pouco sobre o que é. Então nós tínhamos que passar a tubulação. No trecho com água, foi tudo dinamitado aquilo lá, tinha vestígios do TNT. E esse TNT tinha um problema, não sei se era o resultado da combustão, mas tinha, estava contaminada com essa substância aí. Não sei de que forma, só que sei que fui alertado desse problema e a idéia foi fazer uma jangada. Então, pegamos diversos tambores, e a proposta era colocar os trabalhadores para empurrar. (E a jangada, eu era pescador, e como a gente fazia jangada? A gente fazia a jangada com bambu...) Eu disse não, se eu não posso entrar nessa água, eu também não quero que ninguém entre. Não tinha cabimento. E aquele tambor era bem diferente da jangada. Então nós resolvemos emprestar dos bombeiros uma canoa. Não sei se foi dos bombeiros de Atibaia ou de São Paulo, só sei que nós conseguimos o barco. Então nós passamos toda essa tripulação e colocamos os Pitots, eu não sei de quanto em quanto espaço. E ai enquanto eles fotografavam ... com duas panelas, duas assadeiras, por aí, e ele colocou um flash dentro, muito potente. Então 
toda vez que ele acendia o flash, aparecia aquela faixa, mas dava para ver os tipos da pedra, e com um planímetro, media o tamanho médio do perímetro. Depois, eu não me lembro como era feita a relação, sempre tem que ter um critério, às vezes estatístico. Estatisticamente eu faria o valor médio e mediria relativamente. Eu não sei como fizeram. Só que sei que fizeram, apresentaram num congresso e foi muito elogiado. Mas, o que tem de característico no Pitot é que o Pitot não parava. Por que não paravam? Porque foram colocados ventiladores na saída do túnel e na entrada foram colocados... só na saída... A altura e a largura eram medidas, e aí é o problema da raiz. E eu sei que não parava, a gente não conseguia resolver porque isso aí. Porque (...) mesmo a variação de temperatura que fazia variar a densidade, de um lado e de outro da montanha, elas não entravam em um acordo. Variava de um lado e, da natureza variava outro. Então, tinha sempre uma oscilação ali que afetava as medidas, e nessa oscilação tinha perda de carga na tubulação. Agora como foram passadas as tubulações necessariamente tinha que ter ar na entrada e na saída, porque o Pitot mede... relativamente o escoamento local. Eu acho que devia estar sendo medida sim a pressão estática. Acho que fosse o Pitot estático, ele mede a diferença de pressão e para você medir a pressão você tem que ter uma... um dispositivo auxiliar. Então eu já não me recordo muito bem, mas tinha que ter isso aí.

Tinha um micro manômetro...

Professor Geraldo Lombardi: Tinha um micro manômetro Betz de uma precisão de 1/20... nós pegamos um padrão, o padrão na realidade é uma 
coluninha d'água... tem que ter as propriedades da água, você tem que ter a temperatura dela, a pressão eu já não sei se... Construímos esses equipamentos e fizemos o ensaio. São essas coisas que eu me lembro.

Foram dois ensaios: o de 1969 e o de 1972. Em 1969, era para vocês decidirem o quanto deveria ser escavado no túnel, porque ele tinha sido escavado para uma vazão de $22 \mathrm{~m}^{3} / \mathrm{s}$ e essa vazão foi mudada para $33 \mathrm{~m}^{3} / \mathrm{s}$. O primeiro era para saber qual a vazão que o túnel dava e o de $1972 \ldots$

Professor Geraldo Lombardi: Ah sim. O de 1972 eu estava fora. Eu não participei. No primeiro o que a gente queria era a perda de carga para vazão de ar e depois prever a vazão de água. Então foi nesse primeiro aí. Eu sei que foi feito dentro dos moldes do primeiro. A obrigação da gente é fazer o melhor que pode e o melhor que a gente podia fazer foi feito, agora a gente não pode controlar a pressão de entrada e a da saída, nem a pressão estática da saída e nem a dinâmica propriamente, a não ser que você fizesse isso suficientemente elevado para que o ambiente não influenciasse, mas é inadquirivel fazer isso. A gente não esperava que fosse dar esta variação. Seria natural esperar e dar atenção ao problema.

Houve o problema com os ventiladores, nesse primeiro ensaio. Eles não forneceram a vazão que tinha sido projetada par o ensaio...

Professor Geraldo Lombardi: Não deu. Porque veja bem, a curva do ventilador, na realidade, não é importante, se você está excesso de potência, um 
bom excesso de potência, então o trabalho está feito e já não esta dentro da curva, dentro da variabilidade que você consegue, mas não era essa a nossa finalidade, era pegar a velocidade no equipamento e avaliar a rugosidade para poder fazer a avaliação da perda de carga. Então, mas uma coisa a gente pode garantir: o escoamento foi feito exatamente pelo ventilador, e foi uma quantidade suficiente para você poder obter os resultados. Por que estou dizendo isso? Porque que eu estou dizendo isso ai?? Porque eu fiz um experimento com calor e quando mal estava protegendo já tava saindo do regime laminar. Então você tinha um escoamento turbulento, e ai é só você localizar o manual, dai você tem as velocidades e você entra e faz as discussões. É pena que eu não tenha participado do segundo ensaio, agora que você está me falando eu estou lembrando. Mas eu imagino que o segundo, já com a experiência do primeiro, tenha chegado a um resultado mais próximo do real.

O Sr. se lembra como foi que a COMASP chegou até a Escola para que ela fizesse esse ensaio?

Professor Geraldo Lombardi: Eu não lembro. Mas eu imagino que eles tenham procurado o nosso laboratório, porque desde o começo ele foi um laboratório de aplicação prática.O Professor Ruy Vieira era um fluido-mecanicista muito bom e tinha muita influência naquela época, publicações... Eu só posso atribuir isso a ele. Eu tenho a impressão de que foi isso aí, e ele formou um bom grupo. 
O senhor estava começando sua carreira?

Professor Geraldo Lombardi: Eu estava começando minha carreira. Naquela época tinha uma diferença no contrato de professores para a universidade. Eles estavam contratando profissionais de áreas. Tinha maus profissionais, não sabiam trabalhar em grupo, mandava todo mundo embora... mas a contratação era feita porque alguém dizia: 'Ah meu amigo não sei o quê', e era contratado...

Aproveitando que o senhor falou em trabalho em grupo...

Professor Geraldo Lombardi: O Marcius estava liderando também. Era uma pessoa muito madura o Marcius, gosto muito dele, gosto muito do jeito dele. Se eu tivesse que contratar um profissional responsável para gerenciar uma escola que fosse minha, para ele seria atribuído, eu contratava o Marcius. Mas deixa assim essas discussões. Ele tem um sistema didático, é a única pessoa que eu vi até hoje, que leva o experimento para a sala de aula para a demonstração que, tocou o sinal ele começa, tocou o sinal e ele acabou, na hora do sinal. Tudo para ele sai perfeito.

Ele planeja bem o tempo...

Professor Geraldo Lombardi: Eu não sei se é tanto o planejamento ou se é o dom que ele tem, ele tem um dom muito especial. Eu acho que é até naturalmente. A gente tem que planejar, a gente tem que preocupar, agora pode ser que eu esteja falando alguma coisa disso dai e ele reveja de outro jeito. Para 
mim isso é um trabalho, mas talvez para ele isso não seja nada de trabalho, para ele é fácil porque são tão naturais as coisas que ele faz.

Sobre o Método Óptico...

Professor Geraldo Lombardi: O método óptico... nós tínhamos um fotógrafo, o Paulo Pires, ele era o melhor fotógrafo do Brasil, tinha ai uma lista de especialista em fotografia e ele ocupava sempre a primeira posição. Ele era muito criativo e ele tinha muita facilidade. Acho que o mérito desse método foi todo dele, acho que teve outras participações. A gente sempre participava, eu sempre gostei muito de mecânica, então participava mais dessas coisas.

A vazão foi medida por um diafragma, o senhor participou?

Professor Geraldo Lombardi: Parece que sim. Bom, o diafragma, aquele lá era quadrado, aquele túnel era abobadado em cima, era muito grande e eu não sei como é que foi calibrar aquilo lá. Não sei como foi calibrado, mas se foi calibrado foi em modelo, e feito aqui na escola.

Sim, foi feito um modelo do trecho túnel onde seria instalado o diafragma, e o diafragma foi calibrado nesse modelo feito aqui na escola...

Professor Geraldo Lombardi: Isso. E foi colocado no ventilador. Eu não lembro disso. Eu deveria lembrar, mas não tenho memória. Foi no primeiro que foi feito isso? 
Sim.

Professor Geraldo Lombardi: Por que existia o antigo prédio lá em cima, para onde veio a Física Técnica e a oficina mecânica, depois eu não me lembro de ter feito mais alguma coisa, eu não lembro onde foi feito. Eu devia me lembrar e deveria até ter participado, mas disso eu não me lembro de nada. Eu me lembro dos manômetros que foram projetados, as bases foram fundidas, como foram fundidas aquelas bases? Acho que na terra... Foram fundidas em ferro, um peso terrível, agora a hidráulica tem micro manômetro desse daí, suíço com base em alumínio. Eu acho que na época fizemos um manômetro inclinado e funcionava com álcool e água... tinha muito problema de tensão superficial, ele era bem inclinado... tinha que amenizar esse problema da tensão superficial ... agora não me lembro se usamos esses manômetros. É, não me lembro de ter usado, sei que foi construído. Não me lembro.

Bom, vejo que o senhor está um pouco cansado...

Professor Geraldo Lombardi: Mas agora eu estou achando que eu não me lembrei de muita coisa.?

Imagina, lembrou de muita coisa.

Professor Geraldo Lombardi: Bom, você pode aparecer por aqui sempre que você precisar e a gente vê sobre isso aí, mas eu talvez lembre. Eu vou 
conseguindo lembrar, é que eu estou com tanta coisa para fazer, mas de vez em quando eu vou lembrando, eu lembro sim...

Ok, então. Muito Obrigado. A conversa foi muito boa. 
Apêndice $B$

DVD com trechos dos filmes

gravados durante os Ensaios do

Túnel 2 
Apêndice $C$

DVD com fotos dos Ensaios do

Túnel 2 


\section{Bibliografia}

ALTAFIM, R. A. C. (2003). (Org.) 50 anos da EESC: Um olhar no passado visando o futuro, Escola de Engenharia de São Carlos, São Carlos.

ANDERSON, H. and STEVENS, D. (1984). Mono photographic tunnel profiling, Close-range photogrammetry $\&$ surveying state of the art, Pub. American Society of Photogrammetry, U.S.A. pp. 863-869.

ARENS, H. G. (1969). Diâmetro hidráulico de seções irregulares: Determinação por Método Óptico, Revista do Departamento de Água e Esgoto (Revista D.A.E) 72: 287-293.

AZEVEDO NETTO, J. (1976). Abastecimento de água de São Paulo: subsídios para a História ( ${ }^{a}$ parte), Revista do Departamento de Água e Esgoto (Revista D.A.E) 106: 24-27.

AZEVEDO NETTO, J. M., JÚNIOR, E. F. B. and MACEDO, L. H. H. (1978). A Estação de Tratamento de Água do Guaraú: Solução metropolitana dentro da realidade brasileira, Revista do Departamento de Água e Esgoto (Revista D.A.E) 119: 28-40. 
CASTRO, P. P. (1964). Aproveitamento do rio Juquerí para o abastecimento de Água de São Paulo: Ante-projeto, Revista do Departamento de Água e Esgoto (Revista D.A.E) 54: 71-104.

CASTRO, P. P. (1965). O problema do abastecimento de Água para a Área metropolitana de São Paulo, Revista do Departamento de Água e Esgoto (Revista D.A.E) 58: 5-22.

CINTRA, G. (2000). Dados explícitos e implícitos em pesquisa documental, II Congresso Nacional da ABRALIN, Florianópolis.

CLARKE, T. A. (1996). A review of tunnel profiling methods reviewed, optical Metrology Centre - Internal review paper .

CLARKE, T. A. and LINDSEY, N. E. (1992). Profiling methods reviewed, Tunnels and Tunnelling pp. 29-31.

CONTIN NETO, D., GIORGETTI, M. F. and GAVA, R. (1969). Determinação da vazão de Água em túnel por circulação de ar. Dimensionamento de diafragma e seu modelo reduzido, Revista do Departamento de Água e Esgoto (Revista D.A.E) 72: 295-299.

DAEE (1969). Plano global dos recursos hídricos da bacia do piracicaba - 2a etapa, Revista do Departamento de Água e Esgoto (Revista D.A.E) 71: 3639.

de águas e Energia Elétrica DAEE, D. (1986). Plano global dos recursos hídricos da bacia do Piracicaba - 2a etapa, Tecnosan, São Paulo. 
FELLOWS, S. (1976). Tunnel profiling by photography, Tunnels and Tunnelling pp. $70-73$.

FERREIRA, R. K. (1969). A Elevatória Santa Inês do Sistema Juquerí de abastecimento de Água potável À grande São Paulo, Revista do Departamento de Água e Esgoto (Revista D.A.E) 71: 36-39.

FIGUEIRÔA, S. M. (2000). Um Olhar Sobre o Passado: História das Ciências na América Latina, Editora da Unicamp, Campinas.

GAMA, R. (1985). História da Técnica e da Tecnologia: Textos Básicos, T. A. Queiroz, São Paulo.

GAMA, R. (1986). A Tecnologia e o Trabalho na História, Nobel: Editora da Universidade de São Paulo (EDUSP), São Paulo.

GAMA, R. (1990). A tecnologia em questão, Revista USP (7): 43-48.

GIL, A. C. (1991). Como Elaborar Projetos de Pesquisa, Atlas, São Paulo.

IBARRA, N. H. M. J. A. and FRANKLIN, J. A. (1996). Overbreak and underbreak in underground openings part 1: measurement using the light sectioning method and digital image processing, Geotechnical and Geological Engineering 14: 307-323.

JEZLER, H. (1968). COMASP - solução integrada para a produção de Água potável na Área metropolitana de São Paulo, Revista do Departamento de Água e Esgoto (Revista D.A.E) pp. 13-27. 
JEZLER, H. (1970). A consolidação da COMASP como empresa para suprimento de Água potável em Âmbito regional, Revista do Departamento de Água e Esgoto (Revista D.A.E) 76: 37-52.

LÜDKE, M. and ANDRÉ, M. (1986). Pesquisa em Educação; Abordagens qualitativas, EPU, São Paulo.

MAMMANA, C. Z. (1990). Uma teoria da tecnologia, Revista USP (7): 13-22.

MOTOYAMA, S. (1994). (Org.) Tecnologia e Industrialização no Brasil: Uma Perspectiva Histórica, Editora Universidade Estadual Paulista: Centro Estadual de Educação Tecnológica Paula Souza, São Paulo.

MOTOYAMA, S. (2002). (Org.) 50 Anos do CNPq: contados pelos seus presidentes, FAPESP, São Paulo.

QUEIROZ, V. O. S. (1964). Abastecimento de Água na cidade de São Paulo, Revista do Departamento de Água e Esgoto (Revista D.A.E) 52: 30-48.

QUEIROZ, V. O. S. (1966). Abastecimento de Água na cidade de São Paulo, Revista do Departamento de Água e Esgoto (Revista D.A.E) Número Especial: $44-53$.

REDAELLI (1969a). Memória de cálculo da determinação da seção do túnel adutor n. 2, Mémória de Cálculo da Empresa Readelli Engenharia LTDA.

REDAELLI, L. L. (1969b). Sistema Juquerí: Usina Hidroelétrica - Relatório $N$. 4, Redaelli Engenharia Ltda. 
REDAELLI, L. L. (1969c). Usina Hidroelétrica do Guaraú: Adaptação do Túnel N. 2 - Relatório N. 6, Redaelli Engenharia Ltda.

REMENIÉRAS, G. and BOURGUIGNON, P. (1953a). Prédétermination des pertes de charge d'une canalisation d'eau par circulation d'air, Le Génie Civil Tome CXXX(6): 108-11.

REMENIÉRAS, G. and BOURGUIGNON, P. (1953b). Prédétermination des pertes de charge d'une canalisation d'eau par circulation d'air, Le Génie Civil Tome CXXX(7): 131-133.

REMENIÉRAS, G. and BOURGUIGNON, P. (1953c). Prédétermination des pertes de charge d'une canalisation d'eau par circulation d'air, Le Génie Civil Tome CXXX(8): 146-150.

REMEniÉRAS, G. and BOURGUignON, P. (1953d). Prédétermination des pertes de charge d'une canalisation d'eau par circulation d'air, Le Génie Civil Tome CXXX(9): 166-169.

ROUSE, H. and INCE, S. (1957). History of Hydraulics, Dover Publications, New York, New York.

SABESP (2006). http://www.sabesp.com.br, Consulta realizada em 25 de janeiro.

SANCHES, M. G., VERAS, M. C. and de Mattos SILVARES, O. (1969). Determinação da perda de carga hidráulica por circulação de ar, Revista do Departamento de Água e Esgoto (Revista D.A.E) 72: 281-286. 
SANCHEZ, M. G. (1971). Os métodos da COMASP para o estudo das perdas de carga hidráulica em túneis por circulação de ar, Revista do Departamento de Água e Esgoto (Revista D.A.E) - Edição Especial para o VI Congresso da ABES pp. 267-274.

SAVELLI, M. (1964). Histórico do aproveitamento das Águas da região paulista, Revista do Departamento de Água e Esgoto (Revista D.A.E) 53: 82-87.

SHS (1969a). Ensaio Preliminar do Túnel $N^{o}$. 2, Departamento de Hidráulica e Saneamento da Escola de Engenharia de São Carlos, Universidade de São Paulo.

SHS (1969b). Relatório Preliminar Parcial Referente ao Ensaio de Perda de Carga do Túnel $N^{o}$. 2, Departamento de Hidráulica e Saneamento da Escola de Engenharia de São Carlos, Universidade de São Paulo.

SHS (1972). Ensaio de Perda de Carga do Túnel 2 - Sistema Cantareira, Departamento de Hidráulica e Saneamento da Escola de Engenharia de São Carlos, Universidade de São Paulo.

SILVARES, O. M. (1969). Ensaio do Túnel No.2: Pré-Determinação da Perda de Carga no Escoamento de Água por Circulação de Ar, Ante-projeto dos Ensaios do Túnel 2.

STREETER, V. L., WYLIE, E. B. and BEDFORD, K. W. (1998). Fluid Mechanics, WCB/McGraw-Hill, Singapore. 
SUGIMOTO, L. (2004). Como a UNICAMP entrou na era dos computadores há 35 anos, Jornal da UNICAMP 266.

SWECOCONSULT (1968). Relatório RP-GEDE-14-Perdas de Carga no Túnel 2 .

VARGAS, M. (1985). Metodologia da pesquisa tecnológica, Globo, Rio de Janeiro.

VARGAS, M. (1990). Dupla transferência, Revista USP (7): 3-12.

VARGAS, M. (1994). História da Técnica e da Tecnologia no Brasil, Editora da Universidade Estadual Paulista: Centro Estadual de Educação Tecnológica Paula Souza, São Paulo.

VARGAS, M. (1995/1996). Os filtros sociais da tecnologia, Revista USP (28): $222-231$.

YASSUDA, E. R. (1970). Abastecimento de Água na América Latina - aspectos fundamentais, Revista do Departamento de Água e Esgoto (Revista D.A.E) 78: $5-58$.

YASSUDA, E. R. (1976). Programa de abastecimento de Água para a região metropolitana de São Paulo: 1975-78, Revista do Departamento de Água e Esgoto (Revista D.A.E) 107: 20-36. 